\title{
Post-Carboniferous Stratigraphy, Northeastern Alaska
}

By R. L. DETTERMAN, H. N. REISER, W. P. BROSGÉ, and J. T. DUTRO, JR.

GEOLOGICAL S UR VEY PROFESSIONAL PAPER 886

Sedimentary rocks of Permian to

Quaternary age are named,

described, and correlated with

stardard stratigraphic sequences

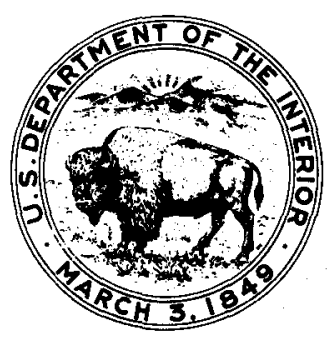

UNITED STATES GOVERNMENT PRINTING OFFICE, WASHINGTON : 1975 


\section{UNITED STATES DEPARTMENT OF THE INTERIOR}

ROGERS C. B. MORTON, Secretary

GEOLOGICAL SURVEY

V. E. McKelvey, Director

Library of Congress Cataloging in Publication Data

Detterman, Robert L.

Post-Carboniferous stratigraphy, northeastern Alaska.

(Geological Survey Professional Paper 886)

Bibliography: p. 45-46.

Supt. of Docs. No.: I 19.16:886

1. Geology-Alaska. I. Detterman, Robert L. II. Series: United States. Geological Survey. Professional Paper 886. QE84.N74P67 $551.7 \cdot 6 \cdot 09798$ 74-28084

For sale by the Superintendent of Documents, U.S. Government Printing Office Washington, D.C. 20402

Stock Number 024-001-02687-2 


\section{CONTENTS}

\begin{tabular}{|c|c|c|c|}
\hline & Page & & Page \\
\hline Abstract & 1 & Stratigraphy - Continued & \\
\hline troduction & 1 & Kingak Shale & 18 \\
\hline Purpose and scope & 1 & Ignek Formation (abandoned) & 20 \\
\hline Geographic setting - & 1 & Okpikruak Formation (geographically restricted) & \\
\hline Previous work and acknowledgments & 1 & kut Formation & \\
\hline Geologic setting & 2 & Graywacke - & \\
\hline tratigra & 5 & Group - & \\
\hline Sadlerochit Group & 5 & tion & \\
\hline ation & 8 & ation & \\
\hline J & 8 & - & \\
\hline ak Member & 10 & n & \\
\hline Iation & 11 & mation & \\
\hline Member & 11 & ation - & \\
\hline mham $\mathrm{H}+\mathrm{CO}$ & 12 & tion & \\
\hline k Siltstone Member & 13 & & \\
\hline a & 14 & llections . & \\
\hline eek Sandsto & 16 & aces cited & \\
\hline
\end{tabular}

\section{ILLUSTRATIONS}

FIGURE

1. Index map of Alaska showing location of report area

2. Map of northeastern Alaska showing location of type sections and reference sections of formations described in this report

3. Generalized geologic map of northeastern Alaska

4. Correlation diagram showing post-Carboniferous stratigraphic sequence in northeastern Alaska

5-14. Stratigraphic columns:

5. Type sections, Echooka and Ivishak Formations

6. Reference section, Shublik Formation; type section, Karen Creek Sandstone

7. Reference sections, Kingak Shale -

8. Type and reference sections, Kongakut Formation

9. Type and reference sections, Bathtub Graywacke

10. Reference sections, Tuktu and Chandler Formations

11. Measured sections, Seabee and Prince Creek Formations _

12. Generalized sections, Schrader Bluff Formation

13. Type sections, members of Sagavanirktok Formation

14. Measured section, Gubik Formation

\section{TABLES}

TABLE 1. Foraminifera distribution chart for the reference section of the Kingak Shale, Ignek Valley

2. Foraminifera distribution chart for Kongakut Formation

22

3. Foraminifera distribution chart for the Nuwok Member of the Sagavanirktok Formation 



\title{
POST-CARBONIFEROUS STRATIGRAPHY, NORTHEASTERN ALASKA
}

\author{
By R. L. Detterman, H. N. Reiser, W. P. Brosge, and J. T. Dutro, Jr.
}

\section{ABSTRACT}

Post-Carboniferous sedimentary rocks exposed in northeastern Alaska constitute an almost continuous sequence representing all systems from Permian to Quaternary. Because the rocks are well exposed, only slightly deformed, and very fossiliferous, they comprise an important biostratigraphic reference section. Regional and local unconformities are present, and minor hiatuses can be identified in the stratigraphic record. The rocks are divided into 3 groups, 14 formations, and 16 members; some are newly named, others revised. The Ignek Formation is abandoned, and the Okpikruak Formation is excluded from the stratigraphic sequence in northeastern Alaska.

The Sadlerochit Formation is raised to group rank and divided into the Echooka (Permian) and Ivishak (Lower Triassic) Formations. The Echooka includes the Joe Creek and Ikiakpaurak Members (both new), and the Ivishak is divided into the Kavik, Ledge Sandstone, and Fire Creek Siltstone Members (all new). The Shublik Formation (Middle and Upper Triassic) is informally divided into siltstone, limestone and dolomite, and clay shale members; it is separated from the Kingak Shale (Jurrassic) by the (Upper Triassic) Karen Creek Sandstone (new). Lower Cretaceous (Neocomian) rocks are mapped as the Kongakut Formation (new). The Kongakut includes the clay shale, Kemik Sandstone, pebble shale, and siltstone members. The Bathtub Graywacke (new) may be in part equivalent to the Fortress Mountain Formation. The Nanushuk and Colville Groups are extended into northeastern Alaska to replace the Ignek Formation. The Nanushuk includes the Tuktu and Chandler Formations, and the Colville is subdivided into its subordinate Seabee, Prince Creek, and Schrader Bluff Formations. All Tertiary rocks are included in the redefined Sagavanirktok Formation, which is divided into the Sagwon, Franklin Bluffs, and Nuwok Members (new). The Gubik Formation (Pleistocene) is extended into northeastern Alaska.

Post-Carboniferous rocks are mainly sandstone, siltstone, shale, and conglomerate, and include both marine and terrestrial deposits with a cumulative thickness of about $8,500 \mathrm{~m}(28,000 \mathrm{ft})$. Marine transgressions and regressions are identified in the stratigraphic sequence, and a major shift from a northern source area for the older rocks to a southern source for the younger rocks is demonstrated. This change took place during the Early Cretaceous, and the Bathtub Graywacke is the first unit to clearly reflect a southerly source area. Post-Carboniferous orogeny in northeastern Alaska started during the Aptian Stage of the Lower Cretaceous. Pre-Aptian sandstones are mature, clean, quartz arenites, whereas most post-Aptian sandstones are lithic arenites or graywackes.

\section{INTRODUCTION}

\section{PURPOSE AND SCOPE}

This summary of post-Carboniferous stratigraphy in northeastern Alaska specificallyencompasses all or part of five 1:250,000-scale quadrangles: Mount Michelson, Demarcation Point, Barter Island, the north edge of the
Table Mountain, and part of the Sagavanirktok (fig. 1). The objective of the geologic mapping and detailed stratigraphic and paleontologic studies during 1969-72 was to investigate surface outcrops of rocks that were penetrated in drilling the discovery well in the Prudhoe Bay oil field in 1968. The fieldwork was supported by helicopter from a base camp at the G. William Holmes Research Station on Lake Peters (fig. 2).

\section{GEOGRAPHIC SETTING}

The post-Carboniferous rocks are exposed along the north flank of the Brooks Range and along the flanks of the Third Range, the Shublik Mountains, and the Sadlerochit Mountains (Reiser and others, 1971). Permian and lower Mesozoic strata are present in several infolds within the Brooks Range, mainly near the upper Echooka, Canning, Aichilik, and Kongakut Rivers. Upper Mesozoic rocks underlie the foothills north of the Brooks Range, and the Tertiary sequence is best exposed along streams on the Arctic Coastal Plain (fig. 3).

Bedrock exposures are generally good in mountainous areas and almost uniformly poor in the foothills and the coastal plain, except where actively eroded by streams. The area is tundra covered, with few trees or brush to obscure bedrock. The highest peaks in the Brooks Range are within the report area, and the topography there has been strongly modified by glaciation. Many small valley glaciers and perennial snow fields occur within the range, and all the major rivers flow in glacially carved, broad, steep-walled valleys. Deposits of former glacial advances obscure bedrock in many places in the foothills and on the coastal plains.

\section{PREVIOUS WORK AND ACKNOWLEDGMENTS}

Post-Carboniferous rocks have been known in northeastern Alaska since the pioneer work of Leffingwell (1919, p. 113-130). Maddren (1912) briefly examined some of the rocks along the Canada-Alaska boundary about the same time as Leffingwell but did little detailed mapping of post-Carboniferous strata. During 1947-53 and in 1968 the U.S. Geological Survey conducted reconnaissance geologic surveys of small parts of the area. Reports by Gryc and Mangus (1947), Whittington and Sable (1948), Morris (1953), Keller, Morris, 


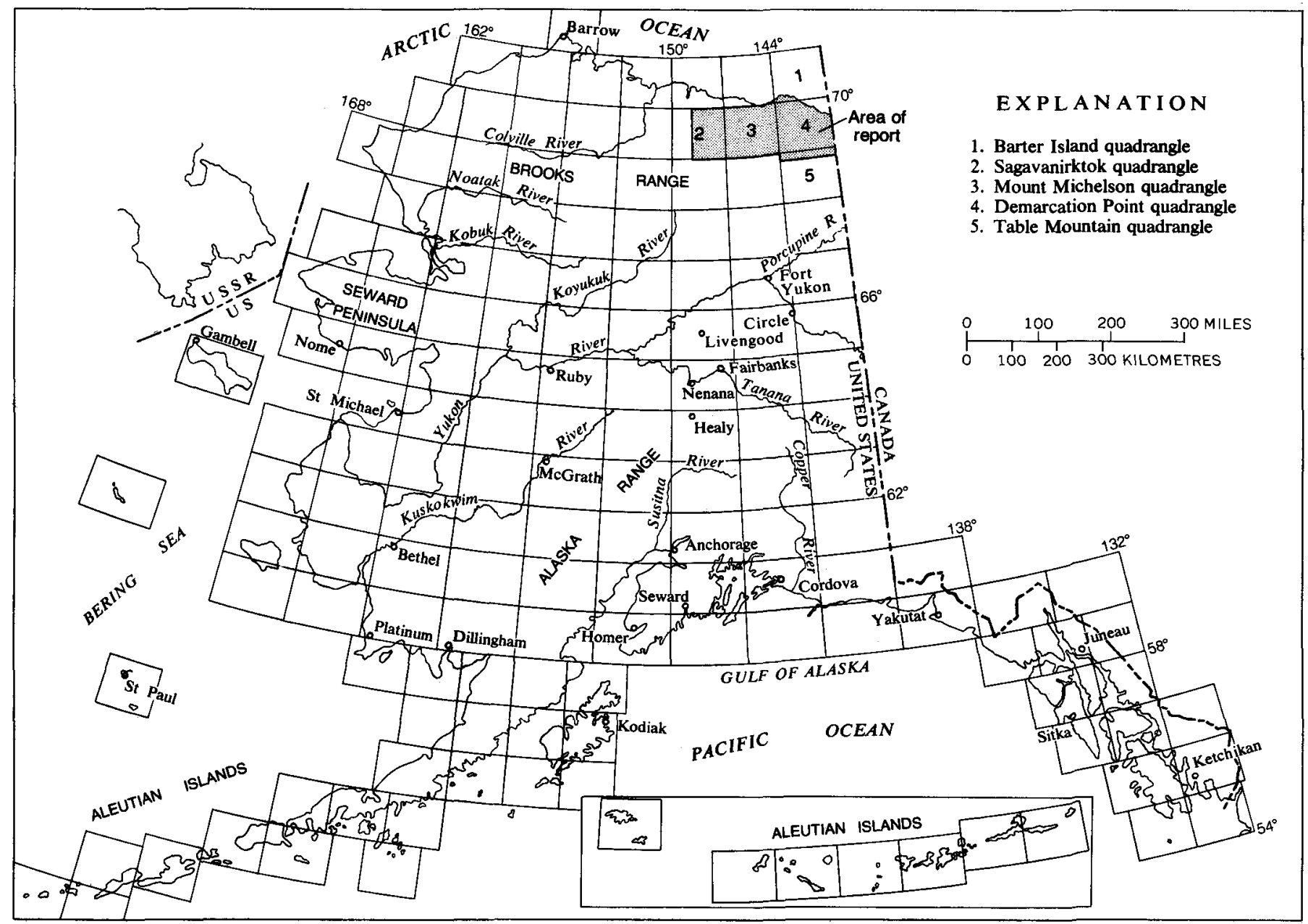

Figure 1.-Index map of Alaska showing location of report area.

and Detterman (1961), Brosgé, Dutra, Mangus, and Reiser (1962), and Reiser and Tailleur (1969) summarize the results of these investigations. Small areas were mapped in detail by Sable (1965) and Reed (1968) for doctoral theses.

The discovery of oil at Prudhoe Bay in 1968 precipitated the recent detailed geologic mapping and stratigraphic studies by the Geological Survey and many private companies. Some preliminary results have been published by Brosgé and Tailleur $(1969,1970)$, Detterman (1970a, b, 1971, 1973), Reiser (1970), Reiser, Dutro, Brosgé, Armstrong, and Detterman (1970), Reiser, Brosgé, Dutro, and Detterman (1971), and Tourtelot and Tailleur (1971). The present report, however, is the first to make major changes and additions to the stratigraphic nomenclature of the post-Carboniferous rocks of northeastern Alaska. This is due largely to the use of the helicopter, which has facilitated access to all parts of the area, making it possible to designate new and better reference sections as well as to locate new stratigraphic units.
Grateful acknowledgment is made to the many geologists in private industry who were working in the area at the time of this investigation. They are too numerous to list here, but several must be acknowledged; these include M. D. Mangus of Calderwood and Mangus, C. G. Mull of Humble Oil and Refining Company, and S. L. Blanton, Jr., of Sun Oil Company. Also, we gratefully acknowledge the work of $R$. W. Imlay, D. L. Jones, N. J. Silberling, W. O. Addicott, and H. R. Bergquist of the U.S. Geological Survey, who identified many collections of fossils obtained during the geologic mapping. The project was also greatly facilitated by logistic support given by the Arctic Research Laboratory, Point Barrow, Alaska.

\section{GEOLOGIC SETTING}

Northeastern Alaska contains diverse sedimentary, metamorphic, and igneous rocks that range in age from Precambrian to Quaternary. All systems of the Paleozoic and Mesozoic as well as most of the Tertiary 


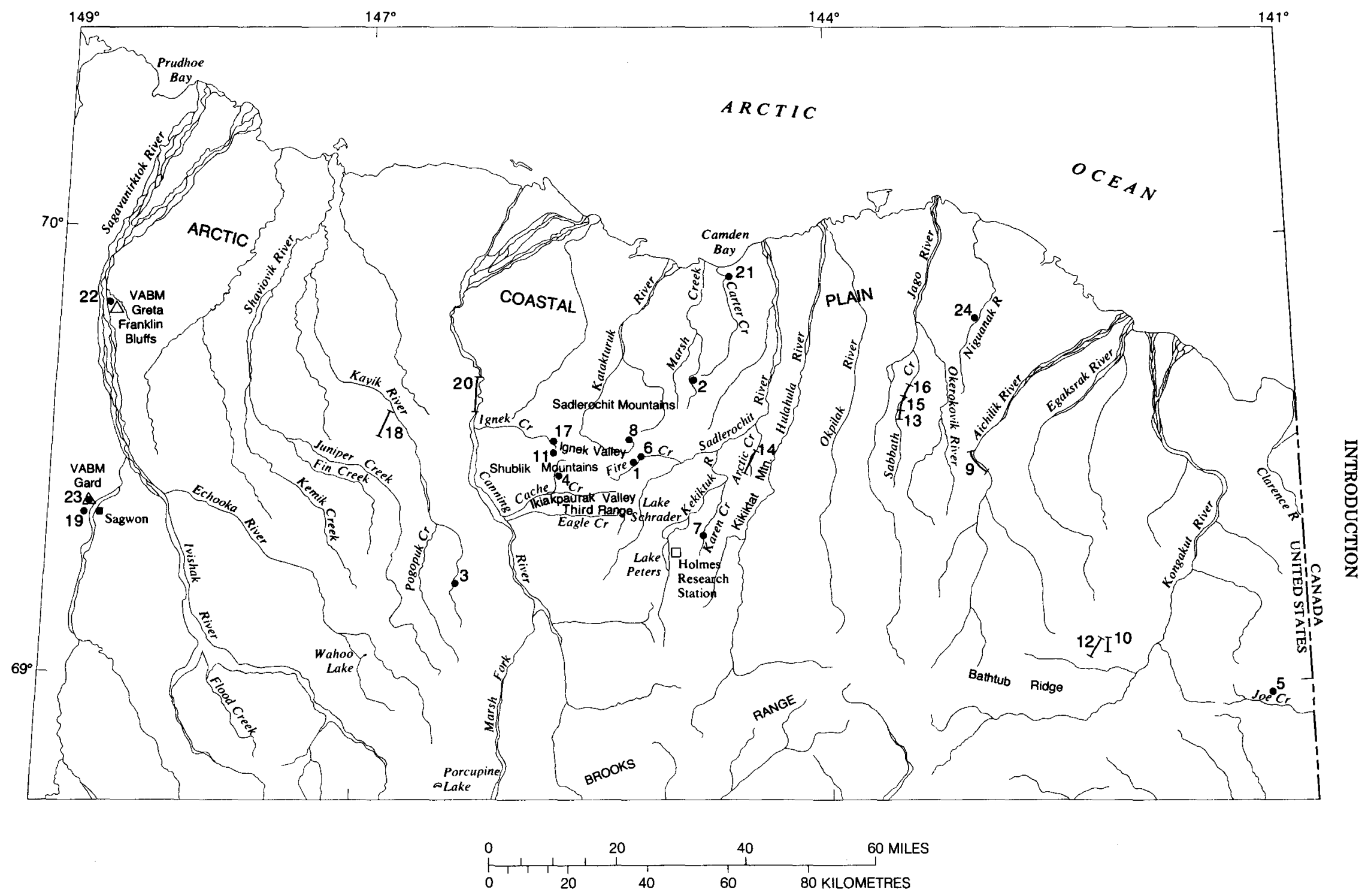

Figure 2.-Map of northeastern Alaska showing location of type and reference sections. Numerals refer to stratigraphic columns on figures 4-13. 


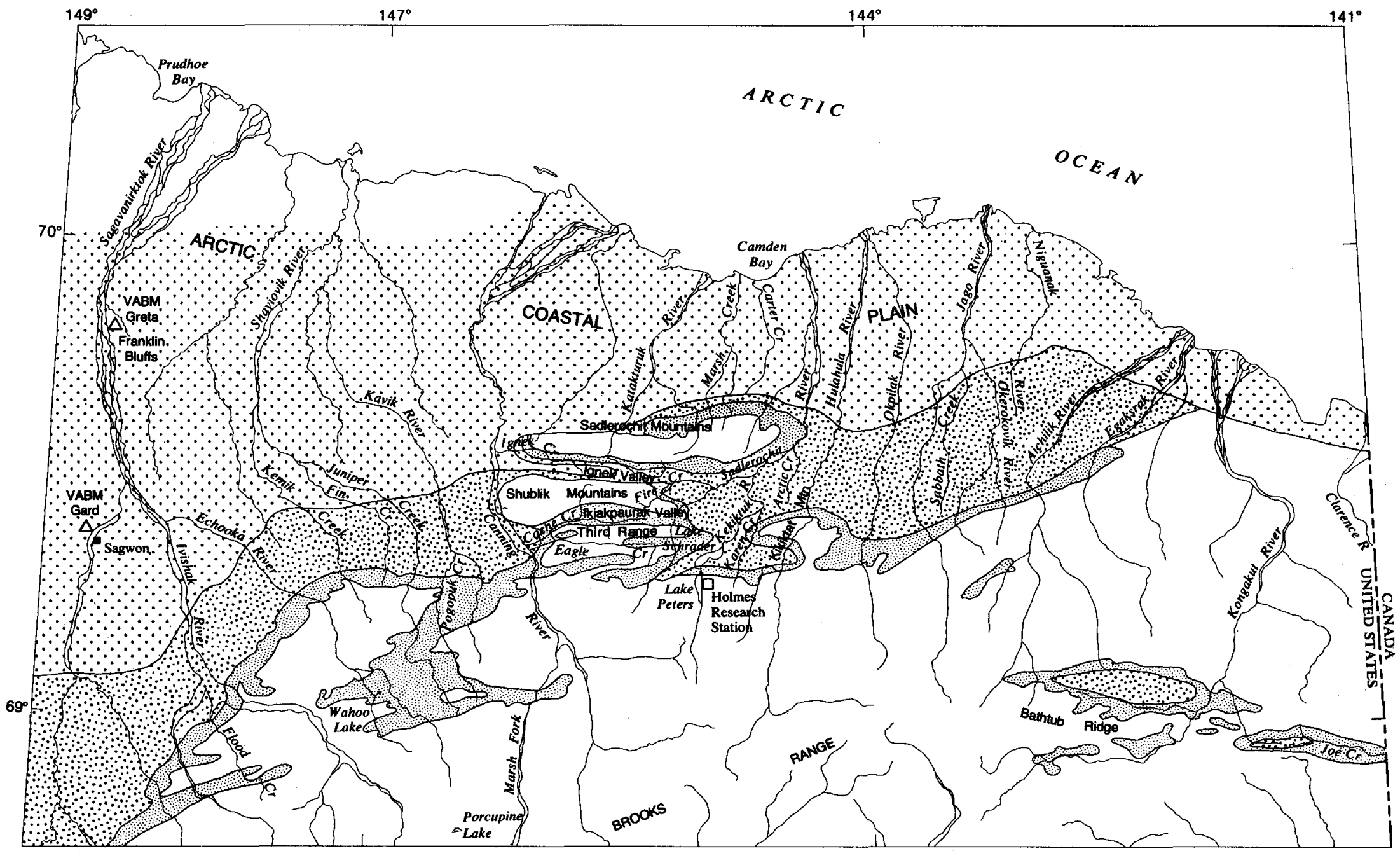

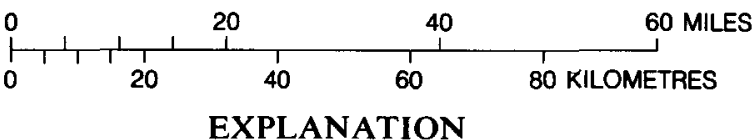

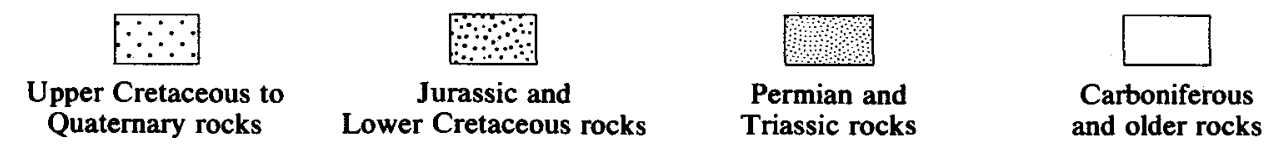

FIGURE 3.-Generalized geologic map of northeastern Alaska. 
are represented. Carboniferous and older rocks underlie all the mountain ranges; the post-Carboniferous rocks flank the mountains and underlie the foothills and coastal plain. Many tectonic episodes are represented by unconformities between rock units, and the provenance of the sediments has changed several times.

The post-Carboniferous sequence (fig. 4) is mainly composed of marine clastic rocks that unconformably overlie the older strata. Nonmarine clastic rocks of Late Cretaceous and early Tertiary age are present locally in the coastal plain, where they overlie the marine strata. Unconsolidated Quaternary surficial deposits mantle all of the units, generally with strong angularity. The post-Carboniferous rocks at the surface are moderately to strongly warped into northeast-trending folds that generally parallel the front of the Brooks Range. The intensity of folding decreases slightly toward the north, but orogenic activity has continued along the Arctic Coast, where Quaternary deposits have been uplifted and slightly folded. Faults cut all the rocks in many places.

\section{STRATIGRAPHY}

Post-Carboniferous rocks form a complex stratigraphic sequence that is widely distributed throughout the Mt. Michelson and Demarcation Point quadrangles (figs. 3 and 4). Most of the names given to rock units by Leffingwell (1919) are retained, but many are modified or revised, and one, Ignek Formation, is abandoned. Some new formations are recognized, mainly in areas that Leffingwell was unable to reach when he did his geologic mapping between 1906 and 1914 .

The Sadlerochit Formation is here raised to group status, and the former Echooka and Ivishak Members become formations; both are in turn divided into new members. The Echooka Formation is divided into the Joe Creek and Ikiakpaurak Members; the Kavik, Ledge Sandstone, and Fire Creek Siltstone Members are the new units of the Ivishak Formation. The Shublik Formation and Kingak Shale are retained much as Leffingwell defined them (1919, p. 115-120), but new and better reference sections are provided and a new stratigraphic unit, the Karen Creek Sandstone, is established to include strata between the two formations.

Leffingwell established the Ignek Formation (1919, p. 120-125) for a sequence of rocks exposed in Ignek Valley and along the lower part of Ignek Creek. He considered these rocks to be of Jurassic(?) age. Subsequent investigations (Gryc and Mangus, 1947) revealed that Early Cretaceous fossils occur in part of these beds and, later still (Keller and others, 1961), that part of the sequence was of Late Cretaceous age. Present usage is to place strata above the Kingak Shale and below Tertiary beds in the Ignek Formation. As this is obviously impractical and has led to numerous discrepancies, we recommend that the term Ignek Formation be abandoned. Most of the rocks included in the Ignek are lithologic and age equivalents of formations and members of parts of the Nanushuk and Colville Groups, names that are widely used in northern Alaska. We propose to extend this usage into northeastern Alaska. Additionally, there are Early Cretaceous rocks exposed in the Mt. Michelson and Demarcation Point quadrangles that do not lithologically fit any present nomenclature. For these rocks we here establish the Kongakut Formation and Bathtub Graywacke. The Kongakut Formation is divided into clay shale, Kemik Sandstone, pebble shale, and siltstone members.

All Tertiary strata in northern Alaska are currently placed in the Sagavanirktok Formation (Gryc and others, 1951, p. 167). The type section at Franklin Bluffs, described originally in only general terms, is here described in considerable detail as the Franklin Bluffs Member of the Sagavanirktok. Leffingwell (1919, p. 129-130) described poorly consolidated late Tertiary beds from Carter Creek near the Arctic coast. He did not name this unit, but the term Nuwok has been used informally for many years. We formalize this name as the Nuwok Member of the Sagavanirktok Formation and describe the type section. The lowest part of the Sagavanirktok is named and described as the Sagwon Member. The youngest bedded rocks exposed in northeastern Alaska are part of the Gubik Formation of Pleistocene age.

\section{SADLEROCHIT GROUP}

The Sadlerochit Formation was named by Leffingwell (1919, p. 113), who used both terms "formation" and "sandstone" to designate this unit. He considered these strata to be Pennsylvanian in age. Smith (1939, p. 32) reported, however, that by the late 1930's G. H. Girty had become convinced that the fauna of the Sadlerochit should be regarded as Permian in age. Subsequent work by the U.S. Geological Survey (Keller and others, 1961) divided this formation into two lithologic units, the Echooka and Ivishak Members, which were, respectively, of Late Permian and Early Triassic age. Additional detailed investigations of the Sadlerochit by the U.S. Geological Survey between 1969 and 1971 indicated that further subdivision of the unit was needed. As the name Sadlerochit is well established for this sequence of beds, we raise it here to group status, and raise the Echooka and Ivishak Members to formational status. This change in rank is essential to permit additional subdivision into members that will facilitate description and correlation between different localities, and between surface and subsurface sections.

The Sadlerochit Group is a heterogeneous assemblage of rocks that includes orthoquartzite, chert, 


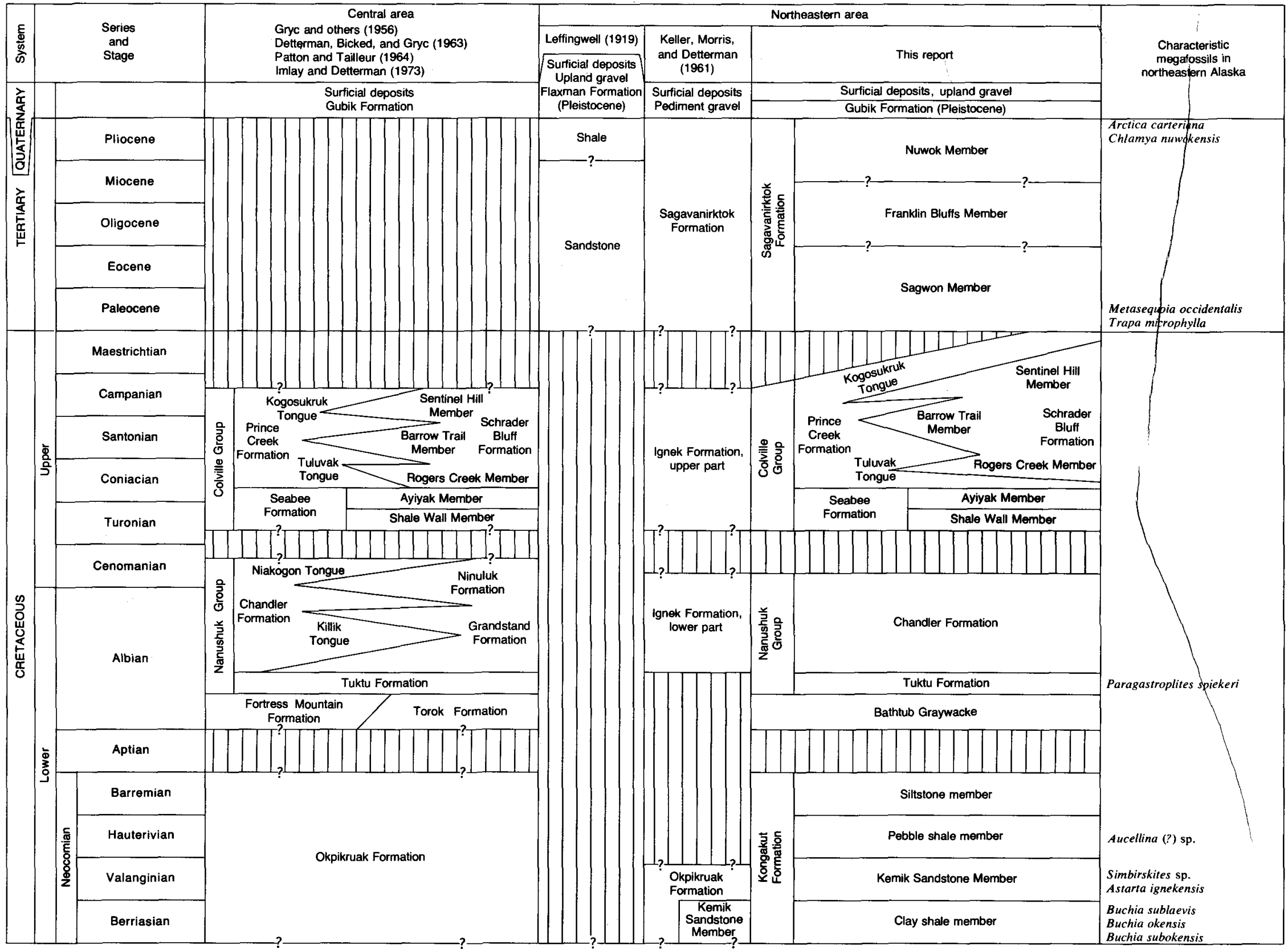

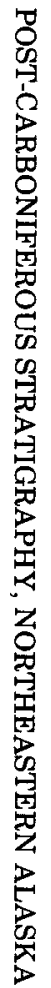




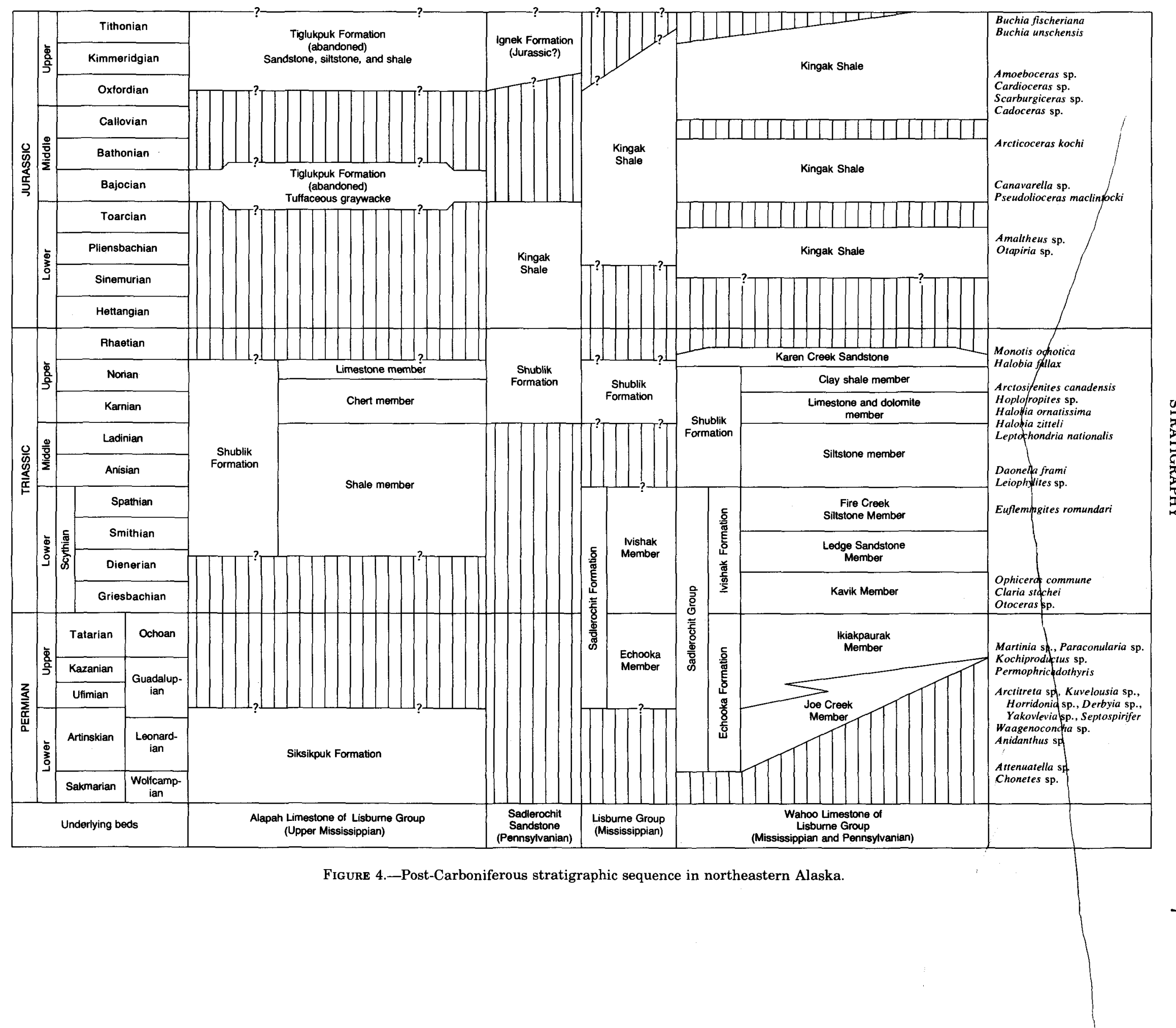


limestone, sandstone, siltstone, and shale. The nomenclature established by Keller and others (1961, p. 178) was an attempt to provide greater continuity for the formation. A detailed study of many more sections of the Sadlerochit in recent years permits further revision that will show even greater lithologic continuity. We here propose two new units within the Echooka Formation; they are in ascending stratigraphic order the Joe Creek Member and the Ikiakpaurak Member. The Ivishak Formation is also divided into the Kavik, Ledge Sandstone, and Fire Creek Siltstone Members. The new members are described individually and type sections are established.

When Leffingwell named the Sadlerochit Formation (1919, p. 113), he indicated it was typically exposed along the south flank of the Sadlerochit Mountains. The mountains are $64 \mathrm{~km}$ (40 mi) long, and there are some changes in lithology and thickness over that distance. We selected a type locality, here designated as the south slope of the Sadlerochit Mountains at a point immediately north of the mesa near the east end of Ignek Valley. At that locality the Sadlerochit Group is about $200 \mathrm{~m}(650 \mathrm{ft})$ thick.

\section{ECHOOKA FORMATION}

The Echooka was designated the lower member of the Sadlerochit Formation by Keller and others (1961, p. 178 ) and the type section was designated on Kemik Creek between latitudes $69^{\circ} 22^{\prime} \mathrm{N}$., and $69^{\circ} 23^{\prime} \mathrm{N}$. The beds exposed there contain elements of both the Joe Creek and Ikiakpaurak Members; consequently, this remains the type section for the entire formation, but new and more completely exposed type sections are established for each new member. The lower $43 \mathrm{~m}$ (140 ft) of the Kemik Creek section is equivalent to the Joe Creek Member, and the remainder is now correlated with the Ikiakpaurak Member.

\section{JOE CREEK MEMBER}

Name and distribution.-A sequence of calcareous siltstone, chert, and limestone is here named the Joe Creek Member for exposures near Joe Creek, a tributary of the Firth River in the northern part of the Table Mountain quadrangle. The type section, exposed along the south slope of the mountains north of the creek, 18.5 $\mathrm{km}(11.5 \mathrm{mi}) \mathrm{N} .68^{\circ} \mathrm{W}$. from the point where Joe Creek crosses the Canada-United States boundary, lat $68^{\circ} 59^{\prime} 30^{\prime \prime} \mathrm{N}$., long $141^{\circ} 26^{\prime} \mathrm{W}$. (fig. 2, loc. 5). The member is also well exposed in the mountains along the southern edge of the Demarcation Point quadrangle. Reconnaissance mapping south of the type area indicates that the member is present in the headwaters of the Coleen River, where a thick and well-exposed section was briefly investigated. The member is probably exposed also throughout the northern and eastern parts of the Table Mountain quadrangle, and thin interbeds of the member are present in many sections of the formation along the north front of the Brooks Range.

Thickness and stratigraphic relation.-The type section of the Joe Creek Member is $113 \mathrm{~m}$ (372 ft) thick (fig. 5). A slightly thicker but less well-exposed section is present on the upper Kongakut River $64 \mathrm{~km}(40 \mathrm{mi})$ to the west, and the section is probably somewhat thicker to the south. The section thins rapidly toward the northwest, where it is interbedded with the Ikiakpaurak Member, and is missing in most of the northeastern exposures of the Echooka Formation.

The type section of the Joe Creek member has three parts. The bottom unit is poorly exposed, predominantly dusky-yellow limy mudstone and calcareous siltstone,

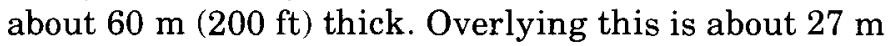
(90 ft) of chert and siliceous siltstone. The remainder of the section is calcarenite and bioclastic limestone.

The fine-grained rocks in the lower part of the member are transgressive onto the underlying Wahoo Limestone of the Lisburne Group. The actual contact is not exposed in any of the sections investigated, but beds within a few feet of the contact indicate no angular discordance, and the contact is considered to be a disconformity. The Ikiakpaurak Member overlies all sections of the Joe Creek Member in the area investigated. At the type section these overlying beds are about $27 \mathrm{~m}(90$ $\mathrm{ft}$ ) thick. The contact is considered gradational and conformable.

Lithology. - The lower part of the Joe Creek Member is primarily a thin-bedded calcareous siltstone and limy mudstone that is 15 to 30 percent detrital quartz. Rounded detrital calcite grains are present in about the same quantity. Euhedral dolomite is a minor but distinctive part of the rock that suggests partial dolomitization after burial. The matrix, mainly clay, forms 20 to 30 percent of the rock. Grain size ranges from 0.02 to $0.05 \mathrm{~mm}$.

The siltstone and limy mudstone in the lower part of the member are poorly indurated and do not form good exposures, but their dusky-yellow to moderate-yellowbrown color makes than a readily mappable unit. Calcarenites interbedded with the siltstone and limy mudstone are tan. The entire lower unit is formed of thin beds, generally about $1 \mathrm{~cm}(1 / 2$ in. or less) thick.

The medium to massively bedded cherts of the middle unit of the member are probably all of secondary origin. They are subvitreous, gray to bluish gray to greenish gray and are composed of both microgranular and spherulitic chalcedonic quartz. The spherulitic quartz is formed mainly in sponge spicules and radiolarian tests.

The limestones in the upper part of the member are clastic rocks. Most are probably quartz calcarenites, 


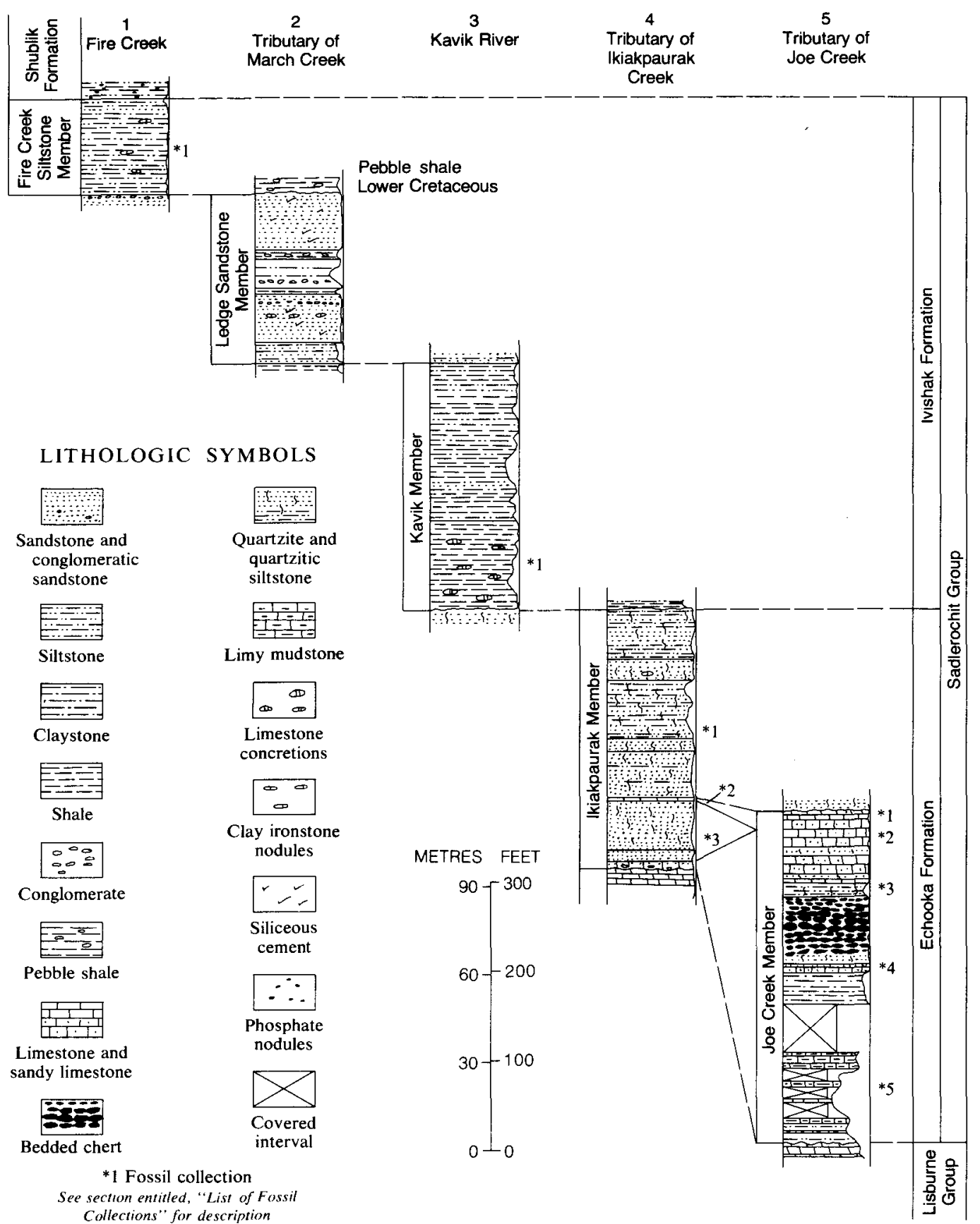

FIgURE 5.--Type sections for members of the Echooka and Ivishak Formation, Sadlerochit Group.

with 10 to 30 percent detrital quartz. The quartz grains are well rounded and generally less than $1 \mathrm{~mm}$ in diameter. A few of the beds are bioclastic limestone or microcoquinite, almost entirely formed of rounded fragments of brachiopods, bryozoans, corals, gastropods, and Foraminifera. Some of the limestone has been partly dolomitized, but the euhedral dolomite generally forms no more than 5 to 10 percent of the rock. Glauconite is a common constituent of the calcarenites. Several thin sections of these limestones contain an opaque material believed to be a petroleum residue within visible pore space in the rock. Bedding within the upper part of the member is mainly thin to medium and irregular.

Age.-The limestone and calcarenite in the upper part of the member are abundantly fossiliferous; some beds are a brachiopod coquinite. The lower part contains scattered fossils, and the chert beds contain little but sponge spicules and radiolarian tests. The brachiopods were identified by Dutro, who considers the fauna to be 
correlative with faunal zones Ea to $\mathrm{G}$ of Bamber and Waterhouse (1971) in the adjoining Yukon Territory. The age of these zones range from Wolfcampian (early Sakmarian) to Guadalupian (early Kazanian). The Joe Creek Member contains the oldest fossils yet discovered in the Echooka Formation of northeastern Alaska.

The Early Permian (Wolfcamp) age is based on collections from the upper Kongakut River and one from Flood Creek, all within the lower part, that are correlated with faunal zone Ea. The main elements of this collection are Attenuatella sp. and Chonetes sp. Four collections, including three from the type section, are correlated with faunal zone $F$ of Bamber and Waterhouse (1971, p. 164-182) and thus are correlated with parts of the Leonardian and early Guadalupian (Artinskian and Ufimian) Stages of the late Early Permian and early Late Permian. The collections from the type section (fig. 5) are all from the limestone and calcarenite overlying the chert beds. Diagnostic brachiopods include Anidanthus sp., Waagenoconcha sp., Septospirifer sp., Derbyia sp., Yakovlevia sp., Horridonia sp., Spiriferella sp., and Kochiproductus sp. Faunal zone $G$ is represented by one collection from near the top of the member on the upper Kongakut River, but is commonly found at the base of the member along the north flank of the Brooks Range. Most of the zone $\mathrm{G}$ collections from the north side of the range are from the basal part of the overlying Ikiakpaurak Member, but some probably represent thin interbeds of the Joe Creek Member. The main elements of this Guadalupian (Kazanian) fauna include Arctitreta sp., Kuvelousia sp., Horridonia sp., Punctospirifer sp., and Neospirifer sp.

In addition to the brachiopod fauna the Joe Creek Member also contains abundant bryozoans and corals, and, less commonly, trilobites and pelecypods. The trace fossil Zoophycos is found throughout the Echooka Formation. Zoophycos is long ranging but in northern Alaska is known only from the Echooka Formation, and is considered a diagnostic fossil for that stratigraphic unit. Microfossils have not been identified in the Joe Creek Member.

\section{IKIAKPAURAK MEMBER}

Name and distribution.-The name Ikiakpaurak Member is here applied to the orthoquartzite, quartzitic sandstone, and siltstone that form the main part of the Echooka Formation along the north side of the eastern Brooks Range.

The member is well exposed at many localities in the eastern Brooks Range. The type locality is on a tributary of Cache Creek, $8.5 \mathrm{~km}(5.25 \mathrm{mi}) \mathrm{N} .45^{\circ} \mathrm{E}$. of the junction of Cache Creek and the Canning River (fig. 2, loc. 4), lat $69^{\circ} 27^{\prime} 45^{\prime \prime}$ N., long $145^{\circ} 53^{\prime} 30^{\prime \prime}$ W., in Ikiakpaurak Valley on the south flank of the Shublik Moun- tains. Here the member is $88 \mathrm{~m}$ ( $290 \mathrm{ft}$ ) thick, but this includes two thin interbeds of the Joe Creek Member (fig. 5). The member is exposed at numerous localities within the range and also overlies the Joe Creek Member at Joe Creek.

Thickness and stratigraphic relations. - The Ikiakpaurak Member is $85 \mathrm{~m}(280 \mathrm{ft}$ ) thick at the type locality, excluding the two thin interbeds of the Joe Creek. Most measured sections of the member range from 61 to $107 \mathrm{~m}$ (200 to $350 \mathrm{ft}$ ). The unit thins persistently and rapidly to the north. About 30 to $40 \mathrm{~m}$ (100 to $130 \mathrm{ft}$ ) is exposed on the south side of the Sadlerochit Mountains; only about $11 \mathrm{~m}(35 \mathrm{ft})$ is present on the north side, and the member is missing in parts of the subsurface along the north coast. The apparent northward thinning of the member probably is due primarily to nondeposition before the time when the northward-transgressing sea covered the northern part of the area. The contact between the Ikiakpaurak Member and the overlying Kavik Member of the Ivishak Formation is conformable to disconformable in most exposures but is locally a disconformity, particularly north of the type locality. The contact of the type Ikiakpaurak with the underlying Joe Creek Member is conformable to gradational, with local intertonguing of the two members. North of the type locality, the Ikiakpaurak lies disconformably on the Lisburne Group.

Lithology.-The Ikiakpaurak Member consists mainly of dark highly quartzose sandstone and siltstone with minor interbeds of silty shale. Locally, in the Sadlerochit and Shublik Mountains, well-defined basal channel conglomerates are present. The pebble- to cobble-sized clasts in the channel conglomerate are all well rounded, about 95 percent black chert derived from the underlying cherty limestone of the Lisburne Group.

The sandstones are mainly fine to very fine grained mature quartz arenites. The subround to subangular grains are commonly cemented by silica that has formed overgrowths on the original grains so that they are tightly interlocking. Thus, the rock could be termed an orthoquartzite. Calcite is less commonly the cementing material. Generally the rocks with calcite cement also contain about 10 percent of detrital glauconite and other impurities and should be termed glauconitic quartz wacke (Williams and others, 1958). The glauconitic beds are most abundant in the basal part of the member. Chert grains in some of the basal sandstones probably were derived from the basal chert channel conglomerate.

The siltstone and silty shale are essentially finegrained versions of the quartz arenites in a siliceous clay matrix. Silica is commonly the cementing material, although authigenic calcite is present in a few beds.

Age. - Two well-defined faunal zones are found in 
the Ikiakpaurak Member; both are early Late Permian in age and are equated with the late Guadalupian (Kazanian) Stage. The lower fauna is mainly from the basal $21 \mathrm{~m}$ (70 ft) of the member and is correlative with the uppermost zone of the Joe Creek Member. A few of the main elements of the brachiopod fauna include Kuvelousia sp., Yakovlevia sp., Waagenoconcha sp., Spiriferella sp., and Neospirifer sp. The upper zone is much less prolific than the lower and contains mainly Martinia sp., Paraconularia sp., Kochiproductus sp., and Permophricadothyris sp.

The lower zone of the Ikiakpaurak Member and the upper zone of the Joe Creek Member are approximately equivalent parts of an arctic Permian fauna that can be correlated with similar assemblages from arctic Cana$\mathrm{da}$, Greenland, Spitzbergen, and Novaya Zemlya. The Ikiakpaurak contains no fossils older than early Late Permian, and as the member rests directly on the Lisburne Group in many places, this indicates that the Permian rocks were deposited by progressive onlap of a northward-transgressive sea.

A few microfossils were obtained from samples 46 to $53 \mathrm{~m}$ (150 to $175 \mathrm{ft}$ ) above the base of the type locality. These fossils, identified by H. R. Bergquist, include Spiroplectamina aff. S. clavata Cushman and Waters, Frandicularia woodwardi Howchin, Ammodiscus bradynus Spandel, and A. nitidus Parr. According to Bergquist (written commun., 1972), these fossils indicate a Permian age, but a precise zonation within the Permian cannot be made.

\section{IVISHAK FORMATION}

The Ivishak was designated the upper member of the Sadlerochit Formation by Keller and others (1961, p. 178), and the type locality was established along the east side of Flood Creek between lat $69^{\circ} 02^{\prime} 40^{\prime \prime} \mathrm{N}$. and $69^{\circ} 03^{\prime} 20^{\prime \prime} \mathrm{N}$. The beds exposed on Floor Creek are not entirely characteristic of the formation as exposed over most of northeastern Alaska, but parts of the recessive Kavik, Ledge Sandstone, and Fire Creek Siltstone Members are present there, and Flood Creek is retained as the type locality for the formation. New type sections are established for each of the new members.

KAVIK MEMBER

Name and distribution. - The name Kavik Member is here applied to a recessive-weathering unit of silty shale and siltstone overlying the resistant quartzose Ikiakpaurak Member of the Echooka Formation and underlying the massive Ledge Sandstone Member of the Ivishak Formation. The Kavik Member is a persistent saddle-forming unit in nearly all exposures of the Sadlerochit Group in northeastern Alaska. Good exposures of the member are rare and generally can be found only where the beds are cut by small actively eroding streams. One such locality along the Kavik River is here designated the type locality; the member is exposed on both flanks of a small anticline between lat $69^{\circ} 17^{\prime} \mathrm{N}$. and $69^{\circ} 18^{\prime} \mathrm{N}$., long $146^{\circ} 52^{\prime} \mathrm{W}$. (fig. 2, loc. 3).

Thickness and stratigraphic relations. - The Kavik Member is $85 \mathrm{~m}(278 \mathrm{ft})$ thick at the type locality. This is one of the thinner sections of the member; it ranges from

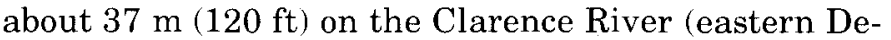
marcation Point quadrangle) to $213 \mathrm{~m}$ (700 ft) on Eagle Creek (central Mt. Michelson quadrangle). The change in thickness is rapid and nondirectional. A section on Pogopuk Creek, $8 \mathrm{~km}$ (5 mi) west of the type locality, is nearly twice as thick as at the type locality. These rapid changes are apparently related to the amount and type of sediments supplied and the depositional environment that existed when these beds were laid down.

The contact with the underlying Ikiakpaurak Member of the Echooka Formation is generally not well exposed owing to the incompetent nature of the basal beds of the Kavik Member. Strata exposed within a few feet of the contact indicate no apparent angular discordance, and the contact is believed to be generally disconformable. However, at a few localities, notably between the Jago River and Lake Schrader, there is a suggestion of a slight angular unconformity. The unconformity is present, also, in the Sadlerochit Mountains and at Prudhoe Bay, where the member lies directly on the Lisburne Group (Fackler and others, 1971).

Lithology. - The Kavik Member consists of thinbedded, laminated, silty shale and siltstone. A few thin, very fine grained, argillaceous sandstone beds occur locally within the member. The laminae are best developed and more distinctive in the southern part of the outcrop area. They are seen in thin section as bands of fairly clean detrital quartz grains alternating with darker bands with a high content of sericitic clay. Organic material is commonly concentrated in the clayrich bands, adding to the overall dark color. Quartz forms about 30 to 40 percent of the rock, generally in well-rounded grains about 0.02 to $0.03 \mathrm{~mm}$ in diameter. A few grains of garnet and zircon are present, but the main constituent is sericitic clay. The clay locally contains some fairly large grains of secondary authigenic calcite. Pyrite cubes, some of which are altered to limonite, are common in these rocks.

The few interbedded sandstones are mainly very fine grained quartz arenites with a clay-rich matrix. Most are thin bedded and grade into siltstone.

Age.- The Kavik Member contains an ammonite and pelecypod fauna of Early Triassic age identified by N. J. Silberling of Stanford University; this is the suite of rocks labeled "ammonite zone" by Keller and others (1961, p. 179). According to Silberling, the two diagnostic fossils from the Kavik are Ophiceras commune Spath and Claraia stache $i$ Bittner. These indicate a late Gries- 
bachian age for at least part of the Kavik Member. Both have been found about $15 \mathrm{~m}(50 \mathrm{ft})$ above the base at the type locality. Otoceras boreale Spath from slightly older Griesbachian beds was reported by Keller, Morris, and Detterman (1961, $p$ 187) from a faulted section on Kashivi Creek.

The presence of these fossils indicates that the base of the Triassic System in northeastern Alaska probably corresponds to the base of the Kavik Member. Uppermost Permian fossils found in the underlying beds are late Guadalupian (Kazanian); this, as well as the change in lithology, suggests a short hiatus between the Ivishak and Echooka Formations.

Only a few microfossils have been obtained from beds of the Kavik Member, and all, according to Bergquist, indicate an age older than that suggested by ammonites and pelecypods. The data cannot be exactly equated, however, as the microfossils and megafossils did not come from the same section. They did come from nearly identical lithology and position above the base of the member but are from sections about $50 \mathrm{~km}(30 \mathrm{mi})$ apart. The fossils include Ammodiscus bradynus Span$\operatorname{del}$ and $A$. nitidus Parr of Permian age, and a few specimens of Textularia fuscalignensis Cushman and Waters of Pennsylvanian age.

The age discrepancy cannot be resolved at present. Three possibilities exist: the fossils were reworked, they extend higher in the section than previously recorded, or there was no break in deposition.

LEDGE SANDSTONE MEMBER

Name and distribution.-The new name Ledge Sandstone Member is here applied to the resistant massive sandstone that forms prominent hogback ridges and cuestas along the north flank of the Brooks Range and along the flanks of the Sadlerochit and Shublik Mountains. Outcrops of this light-colored iron-stained quartzitic sandstone along the south side of the Sadlerochit Mountains are referred to by Leffingwell (1919, p. 113) in his original definition of the Sadlerochit Formation. Keller, Morris, and Detterman (1961, p. 179) informally named this sandstone the cuesta-forming unit. We here name this unit the Ledge Sandstone Member after exposures on Ledge Creek, a tributary of the Sadlerochit River. The massive resistant sandstone forms numerous ledges in this stream near the east end of the Sadlerochit Mountains.

The type section for the Ledge Sandstone Member is here designated as the section exposed along a small eastern tributary of Marsh Creek on the north side of the Sadlerochit Mountains, lat $69^{\circ} 41^{\prime}$ N., long $144^{\circ} 50^{\prime} 30^{\prime \prime}$ W. (fig. 2, loc. 2).

The member is present in all outcrops of the Sadlerochit Group in northeastern Alaska but is thickest and best developed along the north side of the Brooks Range and in the Sadlerochit and Shublik Mountains, where it forms the flanking beds for the older rock units. Within the Brooks Range massive sandstone beds are absent, and the member becomes much thinner and finer gxained southward. Thin sandstone units have been mapped along the north edge of the Table Mountain quadrangle, but the southern limit of these beds is not known. The Ledge Sandstone is present in the subsurface at Prudhoe Bay, where it is the main producing unit in the field.

Thickness and stratigraphic relations. - The Ledge Sandstone Member is $58 \mathrm{~m}$ (189 ft) thick at its type locality, where it is overlain unconformably by Cretace-

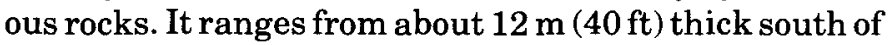
Wahoo Lake to at least $120 \mathrm{~m} \mathrm{(390} \mathrm{ft)} \mathrm{in} \mathrm{an} \mathrm{incomplete}$ section near Monument No. 5 on the Canada-Alaska boundary. It is $141 \mathrm{~m}$ (463 ft) thick in the subsurface at Prudhoe Bay (Fackler and others, 1971) and about $15 \mathrm{~m}$ (50 ft) thick on Joe Creek (Reiser and others, 1974; Mountjoy, 1967).

The contact with the underlying Kavik Member is generally not well exposed except in stream cuts; where seen it is apparently conformable. The contact with the overlying Fire Creek Siltstone Member is also conformable. In two areas the upper contact of the Ledge Sandstone Member is known to be an unconformity: along the north flank of the Sadlerochit Mountains, including the type section, and in the Bathtub Ridge syncline along the upper Kongakut River. In both areas Lower Cretaceous and Jurassic shale rests directly on the sandstone with slight angularity.

Lithology. - The Ledge Sandstone Member is primarily a clean, massive, quartz arenite. Beds range from about 0.6 to $3 \mathrm{~m}$ ( 2 to $10 \mathrm{ft}$ ) thick, and most are a medium light gray to dark reddish brown on weathered surfaces and light gray on fresh surfaces. In thin sections these rocks are seen to be 50 to 60 percent quartz, generally in subround to well-rounded grains 0.05 to 0.1 $\mathrm{mm}$ in diameter. Chert clasts form 30 to 40 percent of the rock. Some of the chert is highly weathered and tripolitic; these grains are white and earthy. Minor accessory minerals include a few grains of highly weathered plagioclase feldspar, zircon, tourmaline, and pyrite. The pyrite is locally abundant and often altered to limonite, giving the sandstone a blotchy appearance and a characteristic reddish-brown weathered surface. These rocks are cemented by silica, but only rarely does it form overgrowths on the detrital grains. Crossbedding, ripple marks, ball-and-pillow structures, and flute casts are common features of the member in all but the northernmost exposures.

Locally the sandstone is conglomeratic, generally in thin well-defined zones in the upper part of the member. 
The constituents are subangular to well-rounded granules to small pebbles of quartz and chert, part of which is tripolitic. The conglomerate beds are more numerous and contain coarser clasts, up to $2.5 \mathrm{~cm}$ (1 in.) in diameter, in the northernmost exposures. The conglomerate disappears rapidly to the south and is generally missing in outcrops south of the mountain front.

A few thin siltstone and silty shale beds are intercalated with the sandstone. Two of these units are present in the type section. The silty zones generally become thicker in a southerly direction and locally divide the sandstone into well-defined lower and upper units. The siltstones are fine-grained versions of the sandstone, with a sericitic clay matrix.

Age.-The Ledge Sandstone Member has only sparse fossils. The massive sandstone beds in the northern part of the area contain the brachiopod Lingula sp. Although of little value for age determination, Lingula is an indicator of the depositional environment. It is found primarily in shallow nearshore environments, and modern forms can live in brackish water.

Ammonites are found at a few localities where the upper sandstone beds become thinner and finer grained than at the type area. Most are fragments and scraps that cannot be identified, but a few complete specimens were identified by N. J. Silberling as Euflemingites cf. E. romunderi Tozer. According to Silverling (written commun., 1971), these are diagnostic of the Romunderi Zone of middle Early Triassic (Smithian) age. Since these fossils are from the upper part of the Ledge Sandstone Member, and the underlying Kavik Member contains fossils of late Griesbachian age, deposition was probably continuous throughout this part of the Early Triassic. The Dienerian Stage is not represented by fossils, but there are ample unfossiliferous beds between the two zones to account for this stage.

FIRE CREEK SILTSTONE MEMBER

Name and distribution.-The Fire Creek Siltstone Member is here named for the siltstone and silty shale sequence that overlies the Ledge Sandstone Member and underlies the Shublik Formation. These rocks are present along the north flank of the Brooks Range and along the Shublik and Sadlerochit Mountains, but good exposures are restricted to stream cuts. The member is named after Fire Creek, where the type section is completely exposed along the west side of the canyon (fig. 2, loc. 1 , and fig. 5) at lat $69^{\circ} 31^{\prime} 45^{\prime \prime} \mathrm{N}$., long $145^{\circ} 13^{\prime} 30^{\prime \prime} \mathrm{W}$. Good exposures are present at a few localities within the Brooks Range, mainly near the Marsh Fork of the Canning River, the upper Kongakut River, and along the west fork of the Aichilik River (Reiser and others, 1971, 1974).

Pre-Cretaceous erosion stripped the member from some of the area now forming the north flank of the Sadlerochit Mountains where the Early Cretaceous Kongakut Formation lies on the Ledge Sandstone Member, and also in part of the Bathtub Ridge syncline on the upper Kongakut River. The member is absent from much of the area between the Aichilik River and the Canadian boundary, probably because of Quaternary erosion. It is known to be present in the subsurface along the north coast (Fackler and others, 1971) and probably is present as far south as Porcupine Lake (Brosgé and others, 1962).

Thickness and stratigraphic relations.-The type section on Fire Creek is $33 \mathrm{~m} \mathrm{(110} \mathrm{ft)} \mathrm{thick;} \mathrm{and} \mathrm{thick-}$ ness of the member ranges from 0 to $135 \mathrm{~m}$ (0 to $440 \mathrm{ft}$ ) elsewhere. Local variations in thickness are common, and due in part to pre-Shublik erosion, but most result from unequal distribution of sediments during deposition. In general the member becomes thicker south and west of the type section and changes from siltstone to shale, reflecting increased distance from the source area (Detterman, 1970a).

The contact between the Fire Creek Siltstone Member and the underlying Ledge Sandstone is conformable and gradational, reflecting only a change in grain size of detrital sediments. The contact with the overlying Shublik Formation is probably a disconformity in some areas. Minor pre-Shublik erosion has removed strata in the northern part of the study area, but beds on opposite sides of the contact are concordant. The contact between the two units is probably conformable in the southernmost exposures in the study area.

Lithology. - The Fire Creek Siltstone Member consists primarily of thin-bedded to massive siliceous siltstone that is commonly laminated. Minor silty shale and argillaceous sandstone are present locally. The rock is medium dark gray to black on fresh surfaces and weathers to lighter shades of gray. The light and dark laminated beds characteristic of some of the outcrops are made up of clay-rich dark layers alternating with quartz-rich light layers. Most of the rocks are cemented by silica, and secondary authigenic calcite has replaced the silica locally. Silica content increases to the south. Mud lumps, worm trails, and clay ironstone concretions are common features of the beds; flute and load casts and drag marks are less common.

Thin sections show that these rocks are 40 to 80 percent distinct mineral grains in a siliceous sericitic clay matrix. The individual grains are all well rounded and mainly 0.01 to $0.025 \mathrm{~mm}$ in diameter. Quartz forms 40 to 60 percent of the rock. Chert locally is as much as 20 percent of the coarse-grained siltstone, and secondary calcite locally amounts to 10 to 15 percent. Where present, the calcite forms aggregates that are much larger than any of the detrital grains; some are 0.5 to $1 \mathrm{~mm}$ in 
diameter. Accessory minerals usually make up only a few percent of the rock. Pyrite altered to limonite is the most common accessory, but a few grains of zircon and garnet are present. Organic material is present in some of the laminated beds, generally concentrated in the clay-rich laminae.

Age. - Fossils in the Fire Creek are sparse, and most are fragments that cannot be identified. A few good specimens of the ammonite Euflemingites cf. $E$. romunderi Tozer and the brachiopod Lingula sp. have been found. These are the same fossils that were found in the upper part of the underlying Ledge Sandstone Member. The fossils were identified by N. J. Silberling, who states (written commun., 1971) that the ammonite is the index fossil of the Romunderi Zone of middle Early Triassic (lower Smithian) age.

Elsewhere in northern Alaska, beds mapped by Patton and Tailleur (1964, p. 431-438) as the lower shale member of the Shublik Formation in the Killik-Itkillik Rivers region may be in part equivalent to the Fire Creek. They report a paleoniscoid fish Boreosomus identified from a few bone fragments; this fish is known only from the Early Triassic. The invertebrate molluscan fauna from correlative beds in the Killik-Itkillik region contains only Middle and Late Triassic forms. However, Euflemingites romunderi Tozer, Posidonia mimer Oeberg, and Pseudomonotis boreas Oeberg were found in the shale member near Galbraith Lake $(83 \mathrm{~km}(52$ mi) $\mathrm{S} 45^{\circ} \mathrm{W}$. of Flood Creek) (Silberling and Patton, 1964) and may indicate a correlation with the Fire Creek Siltstone Member.

The Ivishak Formation contains nearly all of the positively identified Early Triassic invertebrate fossils in Alaska. This identification is based on both ammonites and pelecypods from 25 recent collections. Not all stages of the Lower Triassic are represented by fossils, but unfossiliferous beds lying between good faunal horizons seemingly indicate that deposition was continuous and that a nearly complete Lower Triassic section is present.

\section{SHUBLIK FORMATION}

Name and distribution.-Leffingwell (1919, p. 115) named and described the Shublik Formation for a sequence of dark limestone and shale exposed at Shublik Island, in the Canning River, near the mouth of Cache Creek. He recognized the many structural complications of the Shublik Island section (p. 116) and obtained the stratigraphic details from a section on Camp 263 Creek, near the southeastern end of the Sadlerochit Mountains. During the recent helicopter-supported geologic investigations a more complete exposed section, including both upper and lower contacts, was discovered on Fire Creek, a western tributary of the Sadlerochit River (Detterman, 1970a; Tourtelot and Tail- leur, 1971). This locality (fig. 2, loc. 6) is here designated the reference section for the Shublik Formation; it is located $13.4 \mathrm{~km}(6.3 \mathrm{mi}) \mathrm{N} .84^{\circ} \mathrm{W}$. of the confluence of Fire Creek with the Sadlerochit River, lat. $69^{\circ} 31^{\prime} 45^{\prime \prime} \mathrm{N}$., long. $145^{\circ} 12^{\prime} \mathrm{W}$.

The distinctive lithology and abundant fossils make the Shublik Formation a readily recognized stratigraphic unit in northern Alaska. As a result, the formation is mapped across the entire width of the State. This widespread correlation is undoubtedly due in large part to the included abundant faunal remains, as the lithologic character of the strata changes considerably across the State and the rocks probably should be divided into more than one formation. However, present usage is well established and probably will be continued.

Within the area of this report (fig. 3), the main exposures of the Shublik Formation are in a narrow belt along the north flank of the Brooks Range and along the Sadlerochit and Shublik Mountains (Reiser and others, 1971). As this is a structurally complex area, the beds are missing locally, for example east of the Egaksrak River and along the northwest flank of the Sadlerochit Mountains.Elsewhere the beds are locally duplicated. Structural lows account for the presence of the formation within the Brooks Range near Porcupine and Wahoo Lakes, along the West Fork Aichilik River, and along Joe Creek. The formation is generally the same as at the type locality; however, at Porcupine Lake the Shublik also includes a thick sequence of cherty rocks not found at the type locality. The typical formation is recessive-weathering and does not form good exposures except in stream gorges, but the distinctive coloration and abundant fossils make these rocks readily mappable nonetheless; in addition, they are the only dominantly calcareous Mesozoic rocks in northern Alaska.

Thickness and stratigraphic relations.-The Shublik Formation represents a condensed sequence of rock of remarkably uniform thickness; most sections are 91 to $137 \mathrm{~m}$ ( 300 to $450 \mathrm{ft}$ ) thick. The reference section is $140 \mathrm{~m}$ (458 ft) thick and probably represents about the maximum thickness for the formation north of Porcupine Lake (fig. 6). The upper clay-shale member of the Shublik Formation is similar in many respects to the overlying Kingak Shale of Jurassic age, and in sections where the intervening Karen Creek Sandstone is missing the shale probably has been mapped as part of the Kingak; this may account for the somewhat thinner sections reported by Keller, Morris, and Detterman (1961). Likewise, in sections more than $150 \mathrm{~m}(500 \mathrm{ft})$ thick, structural duplication of beds may have occurred. Such duplication may account for part of the apparent thickness of about $550 \mathrm{~m}(1,800 \mathrm{ft})$ at Porcupine Lake, where about $150 \mathrm{~m}$ (500 ft) of rocks similar to the type 


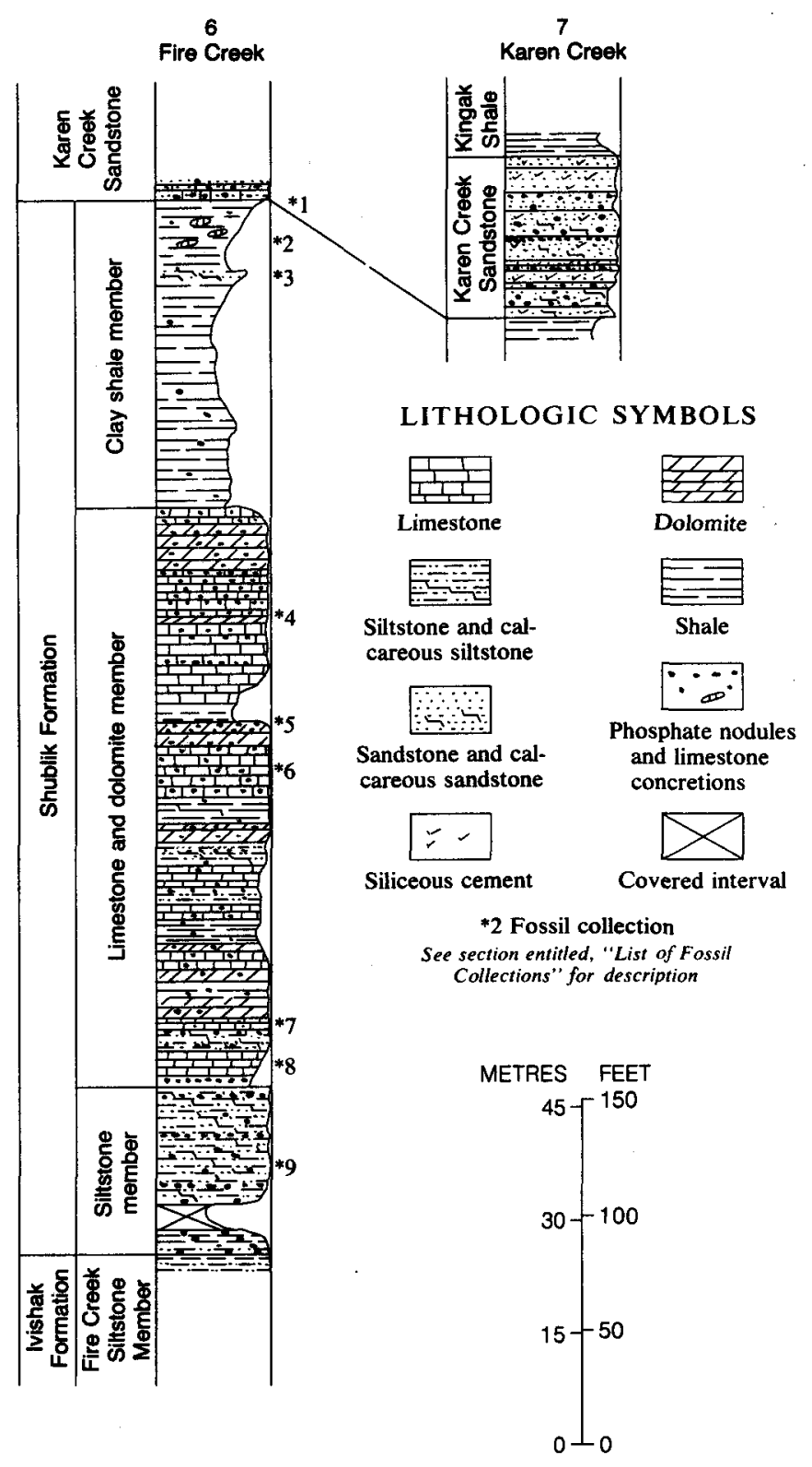

FIGURE 6.-Reference section for the Shublik Formation and type section for the Karen Creek Sandstone.

Shublik are overlain by an estimated $400 \mathrm{~m}(1,300 \mathrm{ft})$ of Triassic cherty rocks not reported elsewhere in northeastern Alaska.

The contacts of the Shublik Formation are generally not well exposed; the reference section on Fire Creek is one of the few localities in which both upper and lower contacts are visible. At Fire Creek the beds appear to be conformable with the underlying Fire Creek Siltstone Member and overlying Karen Creek Sandstone. The Karen Creek Sandstone is locally missing in northeastern Alaska and the Kingak Shale rests directly on the Shublik, so the upper contact of the formation is probably a disconformity there. At Porcupine Lake the loca- tion of the upper contact is uncertain. The fossiliferous cherty beds in the upper part of the Shublik are overlain with apparent conformity by about $30 \mathrm{~m}(100 \mathrm{ft})$ of unnamed unfossiliferous black chert and shale and green argillite, which is succeeded by about $100 \mathrm{~m}$ or dark-gray sandstone of uncertain age.

In most of northeastern Alaska the Shublik Formation is divided informally into three members: in ascending order, siltstone, limestone and dolomite, and clay shale (fig. 6). Patton and Tailleur (1964,p. 431) also used a threefold division for the Shublik in the KillikItkillik area, but a comparison with their sections indicates a considerable change in lithology; a chert member occupies the place of the limestone and dolomite member, and a limestone member is in the place of the clay shale member. Another threefold division is recognized at Porcupine Lake, where the apparent stratigraphic succession is, in ascending order, a shale and limestone member composed of the same rock types found in the reference section, but with less abundant carbonate rocks; a unit of shale, chert, and limestone; and a unit of chert and shale. The lower contacts of the two cherty units may be faulted, and these units may be parts of a single member.

Lithology._All the Shublik Formation north of Porcupine Lake is dark gray to sooty black on fresh surfaces, and the limestone and dolomite, particularly the thin-bedded units, weather light gray to yellowish gray. Phosphate nodules and concretions are abundant, and most of the pelecypods are phosphatized. The nodules and concretions are mainly 0.6 to $1.3 \mathrm{~cm} \mathrm{(1/4} \mathrm{to} 1 / 2$ in.) in diameter and round to irregularly shaped. They consist primarily of isotropic carbonate fluorapatite, although in some the mineral is collophane. Some nodules are ooliths showing concentric banding around quartzgrain nuclei. Nodules are scattered throughout the formation but are most abundant in the siltstone and limestone members, where nodules form beds 2.5 to 15 cm (1 to 6 in.) thick (Detterman, 1970a, b). The phosphate from these nodules gives the rock a characteristic bluish color.

The siltstone member at the base of the Shublik is primarily composed of angular to subangular quartz grains, 0.02 to $0.05 \mathrm{~mm}$ in maximum dimension. Many of the grains are elongate, two to three times longer than they are wide, oriented parallel to bedding. Calcite, mostly of secondary origin, is the cementing material, constituting 20 to 40 percent of the siltstone. Phosphate grains with quartz nuclei are fairly common in some beds, and minor amounts of plagioclase and sericite are also present. The dark coloration is due to the high organic content, but the exact nature of the organic material was not determined.

The limestone and dolomite member of the Shublik 
contains many coquinite layers, most of which are somewhat phosphatized. In thin section these limestones are seen to be primarily composed of tightly compressed flat pelecypod fragments. The several rocks studied in thin section are 40 to 90 percent calcite and 10 to 20 percent secondary dolomite. Chemical analyses of the rocks (Detterman, 1970b), however, indicate that dolomitization is essentially complete in some beds. Subround quartz grains amount to as much as 20 percent of some of the beds; most grains are silt size. These beds probably should be termed silty arenaceous limestone. The limestone is thin bedded to massive, and shale is interbedded with the thin-bedded units.

The clay shale at the top of the formation is a very soft, incompetent rock that does not form good exposures. A few silty, very fine grained calcareous sandstone beds are present near the top, and limestone concretions are fairly common there. Phosphate nodules are a minor part of the section.

The limestone in the unit of shale, chert, and limestone at Porcupine Lake is part black and sooty and part gray, hard, and very fine grained. The chert and silty shale in this unit are dominantly gray to black and weather black, brown, and orange. The overlying chert and shale unit contains conspicuous light-grayweathering olive-green chert and silicified siltstone, in addition to black chert and shale, and small amounts of brown chert and limestone.

Age.-The Shublik Formation is the most richly fossiliferous stratigraphic unit in northeastern Alaska. Ubiquitous flat pelecypods of the monotid and halobiid genera are found in great numbers; many coquinite beds occur throughout the section. These pelecypods have a restricted stratigraphic range and occur worldwide; thus they make excellent horizon markers within the formation. Ammonites are sporadically abundant, as in Ignek Valley and near Wahoo Lake, and provide more refined age assignments for the beds in which they occur.

The lowest beds in the Shublik contain far fewer fossils than the middle and upper parts of the section. The ammonite Leiophyllites(?) sp. was found about $8 \mathrm{~m} \mathrm{(27}$ $\mathrm{ft}$ ) above the base of the siltstone member at the reference locality; this genus is considered to represent the lower part of the Anisian Stage of the Middle Triassic. It overlies by approximately $15 \mathrm{~m}(50 \mathrm{ft})$ a specimen of Euflemingites romunderi Tozer in the Fire Creek Siltstone Member of the Ivishak Formation of middle Early Triassic (lower Smithian) age according to N. J. Silberling (written commun., 1971). Fossils characteristic of the Spathian Stage have not been found but are probably represented by the $15 \mathrm{~m}(50 \mathrm{ft})$ interval between the two ammonite collections. Deposition across the formation boundary at the reference section is considered to be essentially continuous and conformable. Daonella frami Kittl of early Ladinian age has been found at the top of the siltstone and the base of the limestone members.

The limestone member, except for the basal beds, is of early Late Triassic (Karnian) age. Many fossils are found including Halobia cf. H. zitteli, Halobia ornatissima, Lima sp., Gryphaea sp., Camptonectes sp., Leptochondria nationalis, and the ammonites Tropites sp., Holotropites sp., Sirentites sp., Arctosirentites cf. A. canadensis Tozer, Juvavites sp., and Arcestes(?) sp. Rhynchonellid brachiopods and gastropods are also common throughout these beds. These fossils indicate that the entire Karnian State is present.

Numerous vertebrate fragments were found in the limestone member on the north side of Ignek Valley near the west end of the Sadlerochit Mountains. According to C. A. Repenning of the U.S. Geological Survey, these bones represent the ichthyosaur family Shastosauridae (written commun., 1972). Unidentifiable bone fragments are present in other collections from the member.

Fossils in the clay shale member are primarily confined to the limestone concretions and limy sandstone beds in the upper part and include the pelecypods Monotis cf. $M$. obtusicostata Westermann, Monotis cf. $M$. scutiformis pinensis Westermann, Halobia ef. $H$. fallax Mojsisovics, and Halobia cf. $H$. lineata Mojsisovics. These beds are correlated with the middle Norian Stage of the Late Triassic. Fossils of the late Norian Stage are found at the base of the overlying Karen Creek Sandstone. The completeness of the fossil record suggests that deposition was continuous throughout the entire Triassic.

The shale and limestone member at Porcupine Lake contains Halobia cf. $H$. zitteli and tropitid ammonites, indicating a Karnian age. The unit of shale, chert, and limestone contains Monotis sp. and Halobia sp., probably of middle Norian age. The overlying unit of chert and shale contains Monotis sp. of middle or late Norian age and Monotis sp. similar to $M$. subcircularis or $M$. ochotica, which are of late Norian age. The sequence of fossils indicates that the Shublik at Porcupine Lake may be equivalent in age to the limestone and dolomite and clay shale members and to part of the Karen Creek Sandstone of the type area and that the cherty units are younger than the chert member of the KillikItkillik area.

\section{KAREN GREEK SANDSTONE}

Name and distribution.-The Karen Creek Sandstone is here named for a thin sequence of dark, resistant, quartzitic sandstone that lies between the recessive-weathering Shublik Formation and the overlying Kingak Shale. The type section is the west bank of 
the upper part of Karen Creek (fig. 2, loc. 7), $5.1 \mathrm{~km}(3.2$ mi) S. $48^{\circ} \mathrm{E}$. of the outlet of Lake Schrader, lat $69^{\circ} 22^{\prime} \mathrm{N}$., long $144^{\circ} 49^{\prime} \mathrm{W}$. These beds were referred to the base of the Kingak Shale by Reed $(1968$, p. 56$)$.

The Karen Creek Sandstone has a restricted distribution. It is best exposed along the north front of the Brooks Range between the Kavik and Aichilik Rivers, where it forms distinctive hogback ridges that are readily mappable. Fairly good exposures of the sandstone are present at a number of localities in Ignek Valley and along the north side of Kikiktat Mountain. It also underlies small areas between Lake Schrader and the Sadlerochit Mountains but has not been found within the Brooks Range.

Beds that are probably lithologically equivalent to the Karen Creek Sandstone are penetrated in drilling along the Arctic Coast. In the subsurface similarlooking sandstones were named the Sag River Sandstone (Rickwood, 1970; Fackler and others, 1971). This unit occupies the same stratigraphic position and is lithologically very similar to the Karen Creek Sandstone, but a correlation between the two has not yet been established.

Thickness and stratigraphic relations.-Measured sections of the Karen Creek Sandstone range in thickness between $3 \mathrm{~m}(10 \mathrm{ft})$ on the Kavik River to $38 \mathrm{~m}$ (125 $\mathrm{ft}$ ) near the Jago River. The type section is $21 \mathrm{~m}(70 \mathrm{ft}$ ) thick (fig. 6). These sections indicate there is a persistent but nonuniform thinning from east to west along the Brooks Range. A similar decrease in section is

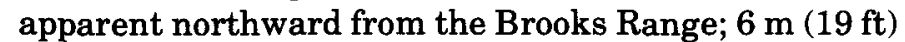
is present along Fire Creek and slightly more in Ignek Valley, whereas $32 \mathrm{~m}(105 \mathrm{ft})$ is exposed to the south near the upper Sadlerochit River. Sections of Sag River Sandstone encountered in drilling along the north coast exhibit a pattern of thinning in an easterly and southerly direction, the reverse of that seen in outcrop (Fackler and others, 1971).

The provenance of the Karen Creek Sandstone cannot be precisely determined from present data. Strictly on the basis of outcrop information, the apparent source would be to the southeast; however, petrographic examination of thin sections strongly suggests that the provenance for the sediments was the same as for the underlying Shublik Formation and Sadlerochit Group, that is, from the north. Also, the presence of chert and shale at Porcupine Lake suggests that deeper water lay to the south.

The contact between the Karen Creek Sandstone and the underlying Shublik Formation is considered to be conformable. The bottom side of the lowest sandstone bed is undulatory in some exposures but is always resting on the clay shale at the top of the Shublik. Fossils in the lower part of the sandstone and in the upper part of the shale indicate, also, that no significant break in deposition occurred between the two stratigraphic units. The upper contact with the Kingak Shale is structurally conformable, but the lithology and faunal content of the immediate overlying rocks change considerably and possibly indicate a disconformity.

Lithology. - The Karen Creek Sandstone is primarily a very fine grained, massively bedded, dark, siliceous quartz arenite. There is little or no lateral change in composition of the rock in exposures immediately adjacent to the north front of the Brooks Range. Thin sections show that these rocks are 45 to 75 percent quartz in subround to well-rounded grains 0.07 to $0.15 \mathrm{~mm}$ in diameter. Chert grains form another 10 to 20 percent. Secondary calcite is as much as 10 percent of some beds, and siderite replaces the calcite in a few. All the thin sections examined showed a dark organic stain throughout that may be responsible in part for the overall dark color. Accessory minerals account for less than 5 percent of the rock and generally include collophane, glauconite, sericite, zircon, plagioclase, pyrite, limonite, and locally ilmenite and leucoxene.

Large irregular to colloform phosphate nodules are common throughout the Karen Creek Sandstone. Many of the nodules are as much as $7.6 \mathrm{~cm}$ ( 3 in.) in diameter, considerably larger than any noted in the underlying Shublik Formation. Some nodules are ooliths showing a distinct accretionary banding around quartz-grain nuclei but with no orientation of the ooliths. Reed (1968, p. 58) presents good evidence that the nodules in the Karen Creek were formed penecontemporaneously with the deposition of the sandstone and suggests that they were not derived from the underlying Shublik Formation.

The northward thinning of the Karen Creek Sandstone away from the mountain front is accompanied by a considerable change in its lithologic character. Much of the silica is replaced by calcite, and some of the rocks are arenaceous limestones. In some beds the calcite has been altered to dolomite and siderite. The upper $0.6 \mathrm{~m}(2 \mathrm{ft})$ of the Fire Creek section is nearly pure dolomite and siderite. This northerly change to dominantly calcareous rocks apparently reflects a depositional peculiarity of the area, as the presumably equivalent Sag River Sandstone present in the subsurface along the north coast is similar to the Karen Creek Sandstone exposed along the mountain front.

Age. - The Karen Creek Sandstone must be considered the uppermost stratigraphic unit of the Triassic on the basis of the pelecypods Monotis ochotica ochotica (Keyserling) and Gryphaea keilhaui Boehm, which are found in considerable numbers in the lowermost beds in the northernmost exposures. According to N. J. Silberling (written commun., 1969), these fossils are charac- 
teristic of the upper Norian Stage of Late Triassic age. Fossils have not been found in any of the exposures immediately adjacent to the north front of the Brooks Range. The presence of phosphate nodules in these beds also suggest a correlation with the highly phosphatic rocks of the Shublik Formation. The overall lithology of the Karen Creek Sandstone, on the other hand, is different enough from the Shublik to suggest a change in depositional environment, and logically the Karen Creek should be considered the beginning of the Jurassic. These beds may actually cross the TriassicJurassic boundary, but until definite evidence is found, they will be considered uppermost Triassic.

\section{KINGAK SHALE}

Name and distribution.-The Kingak Shale was named and described by Leffingwell $(1919$, p. 119) for exposures of dark shale at Kingak Cliff, near Camp 263 Creek, and at the southeast end of the Sadlerochit Mountains. The shale is exposed along both sides of the Sadlerochit River at this locality but, owing to structural complications, good sections are hard to find. The Kingak is a soft shale unit that forms poor exposures; it is responsive to even the mildest tectonic activity. Two reference sections (fig. 2, locs. 8 and 9 , and fig. 7) are designated to supply stratigraphic details that are not completely exposed in Leffingwell's type locality. The section from Ignek Valley (fig. 2, loc. 8) is exposed beneath the sandstone capping the mesa near the east end of the valley, lat $69^{\circ} 33^{\prime} 30^{\prime \prime}$ to $69^{\circ} 34^{\prime} \mathrm{N}$., long $145^{\circ} 20^{\prime}$ to $145^{\circ} 20^{\prime} 30^{\prime \prime} \mathrm{W}$. This section is about $19.3 \mathrm{~km}(12 \mathrm{mi})$ west of Leffingwell's type locality and contains only Middle and Upper Jurassic rocks; it rests disconformably on the Shublik Formation. The other reference section is exposed along the west bank of the Aichilik River, lat $69^{\circ} 31^{\prime} 15^{\prime \prime}$ to $69^{\circ} 32^{\prime} \mathrm{N}$., long $143^{\circ} 03^{\prime}$ to $143^{\circ} 05^{\prime} \mathrm{W}$. (fig. 2 , loc. 9); it contains a complete Jurassic section, but parts are duplicated by folding and faulting.

The Kingak Shale underlies the lowlands north of the mountain front, where it forms a belt of subdued topography 1.6 to $10 \mathrm{~km}$ (1 to $6 \mathrm{mi}$ ) wide parallel to the mountains. Exposures are confined to stream cutbanks, with rubble and float covering the hills between streams. Recent mud slides on hill slopes are commonly a clue to the presence of the underlying shale. The series of discontinuous cutbanks about $10 \mathrm{~km}(6 \mathrm{mi})$ long on the west side of the Canning River, along with Black Island in the Canning River, is perhaps the best known occurrence of the Kingak. Another extensive outcrop is present along the west bank of the Aichilik River, and is here designated a reference locality (fig. 7) along with the one exposed under the mesa at the east end of Ignek Valley.

Exposures of the Kingak Shale are rare within the

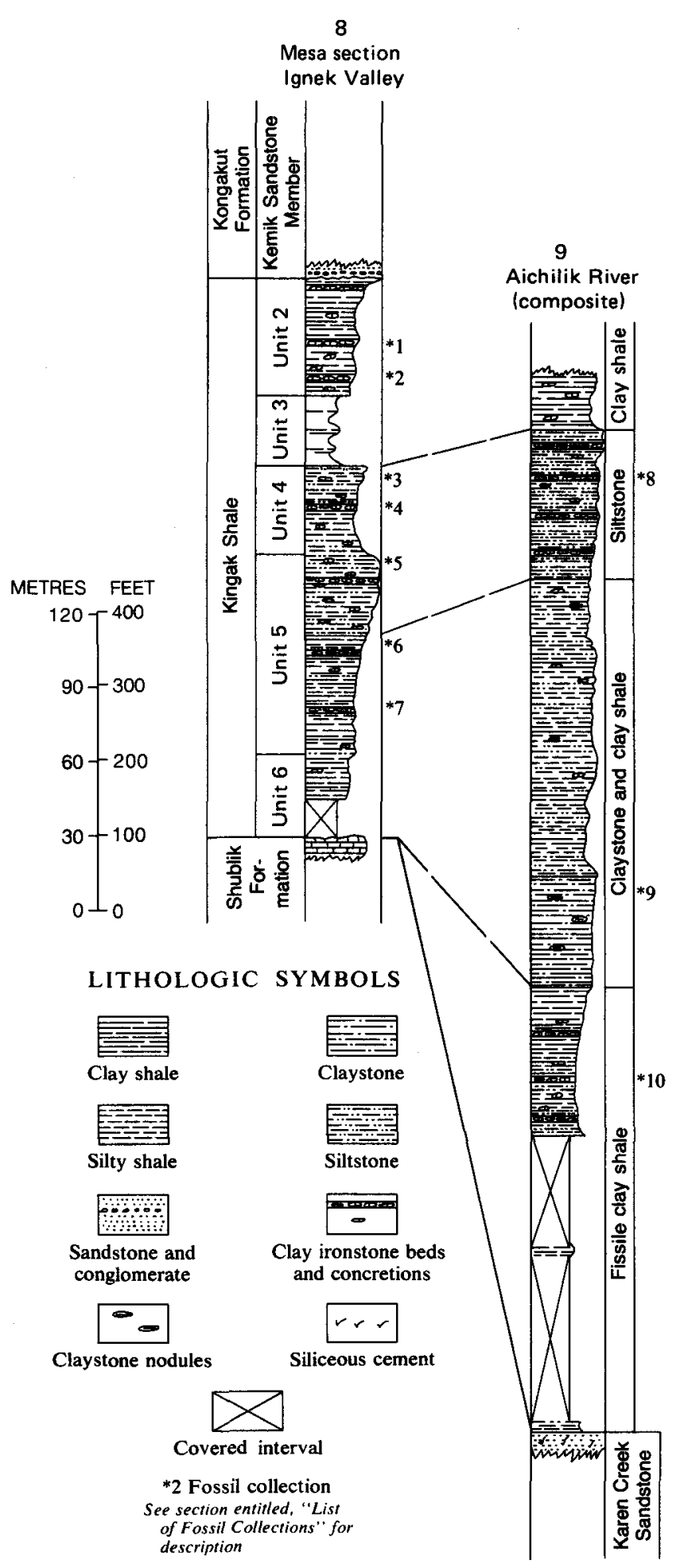

FigURE 7.-Reference sections for the Kingak Shale.

Brooks Range. One of the few localities is along Joe Creek, in the southeastern part of the map area, where a fairly thick sequence of beds is exposed along the south bank of the creek (Reiser and others, 1974). Other small patches of Kingak are present between the upper 
Echooka and Kavik Rivers (Reiser and others, 1971).

Thickness and stratigraphic relations. - Stratigraphic measurements of the Kingak Shale are impaired by folding and faulting and by the lack of continuously exposed sections. Leffingwell $(1919$, p. 119) estimated a thickness of about $1,200 \mathrm{~m}(4,000 \mathrm{ft})$ for his type locality near Camp 263 Creek. This may be somewhat excessive, but a similar thickness is apparently present along the Canning River, and $915 \mathrm{~m}(3,000 \mathrm{ft})$ is reported from Kemik Creek (Keller and others, 1961, p. 192). The thickness of the Kingak changes rapidly within short distances. Exposures in Ignek Valley range between 46 and $366 \mathrm{~m}$ (150 and 1,200 ft) and lie between $1,200 \mathrm{~m}(4,000 \mathrm{ft})$ sections on the Canning River and at Camp 263 Creek.

There are few good horizon markers in the Kingak Shale that can be followed with confidence while correlating detailed sections. Fortunately, there are fairly abundant ammonites and pelecypods with restricted stratigraphic range that can be used as indicators of duplication or omission of strata. Numerous diastems can be demonstrated within the Kingak by using a combination of these faunas and their associated lithologies. These same criteria are used to show the disconformable nature of both the upper and lower contacts.

Lithology._The Kingak Shale consists primarily of shale. However, siltstone, claystone, and clay ironstone are important subordinate elements of the stratigraphic sequence. The shales are uniformly dark gray to dark olive gray and black, but some have distinctive features that make assignment to a specific part of the section possible.

The lowest part of the Kingak is an extremely fissile black paper shale as much as $180 \mathrm{~m}(600 \mathrm{ft})$ thick. The shale fractures and weathers into thumbnail-sized silvery fragments. Large cannonball concretions occur through an interval of about $45 \mathrm{~m}(150 \mathrm{ft})$ in the middle of the fissile shale unit. Overlying the fissile shale beds are $100 \mathrm{~m}(300 \mathrm{ft})$ to $300 \mathrm{~m}(1,000 \mathrm{ft})$ of soft dark-gray clay shale and locally claystone. The upper part of this sequence contains a few beds and nodules of clay ironstone that characteristically weather a bright brick red.

Thin-bedded siltstone and silty shale overlying the clay shale constitute the most resistant part of the Kingak Shale. Thin sections show that the siltstone is about 75 to 80 percent rounded quartz grains generally less than $0.05 \mathrm{~mm}$ in diameter. Siderite makes up 5 to 10 percent of the siltstone, and there are minor amounts of plagioclase, zircon, and pyrite and a few grains of phosphate and glauconite. The matrix is a siliceous clay. The siltstone mineralogy is strikingly similar to that of the Karen Creek Sandstone. This siltstone and silty shale sequence contains the most prolific ammonite and pelecypod fauna of the Jurassic in northeastern Alaska. Black clay shale with siltstone interbeds and irregularly shaped, gray, clay-ironstone nodules overlies the siltstone unit and forms the upper part of the Kingak Shale north of the Brooks Range.

The rocks exposed on Joe Creek are mainly a darkgreenish-gray siltstone with interbeds of shale and clay ironstone. These beds are slightly younger than most of the strata exposed on the north side of the range and probably represent a sequence that was almost entirely removed there.

Age.-The Kingak Shale was considered to be Early Jurassic by Leffingwell (1919, p. 119). Subsequent investigations have shown that probably all parts of the Jurassic are included in the beds now mapped as Kingak. The stages are not all represented by fauna, but there are sufficient unfossiliferous beds to represent intervals not accounted for by fossils. Owing to the many diastems characteristic of the Kingak deposition, no single exposure contains all the presently known stages.

The Early Jurassic, with sparse fossils in northeastern Alaska, is represented by Amaltheus cf. .A. stokesi (Sowerby) and the pelecypod Otapiria tailleuri Imlay. The pelecypod indicates a probable Sinemurian age, and the ammonite is Pliensbachian (Imlay and Detterman, 1973). These fossils are from the fissile clay shale and claystone in the lower part of the sequence.

Leffingwell (1919, p. 119) based his age assignment for the Kingak Shale in part on the presence of the crinoid Pentacrinus subangularis var. alaska Springer. He collected many beautiful specimens on Black Island in the Canning River. We collected this crinoid at a number of additional localities, it may be basal Middle Jurassic rather than Early Jurassic, as dwarf forms of Pentacrinus were associated with the basal Bajocian ammonite Pseudolioceras. However, there may be two species of Pentacrinus in northern Alaska, one a dwarf and the other a robust form similar to that from Black Island. The two are never found together, and the large form has never been located with other fossils but does underlie Amaltheus on the Aichilik River.

The siltstone and shale sequence of the Kingak carries a prolific ammonite and pelecypod fauna of Middle Jurassic age. Beds at the base contain abundant Pseudolioceras maclintocki (Haughton), P. whiteavesi (White), and Canavarella cf. C. belophora Buckman, all of basal Bajocian age. The next higher beds contain the middle Bajocian ammonite Arkelloceras sp., which in turn is overlain by abundant Arctioceras kochi Spath, A. kochi var. pseudolamberti Spath, and Choffatia cf. C. subbakeriae (d'Orbigny), of late Bathonian age. Much of the Callovian Stage is apparently missing in northern Alaska, but Cadoceras sp., Pseudocadoceras grewingki 
(Pompeckj), and Reineckia cf. R. stuebeli Steinmann were collected. The pelecypod Inoceramus cf. I. lucifer Eichwald is fairly abundant in parts of the Bajocian and Bathonian.

Beds of Late Jurassic age contain a sparse ammonite fauna in their lower part, including Cardioceras sp. and Cardioceras (Scarburgiceras) sp. of early Oxfordian, and Amoeboceras (Prianodoceras) cf. A. (P.) transitorium Spath of late Oxfordian age. The overlying beds contain only the pelecypod Buchia, but the various species occupy a restricted stratigraphic range and permit fairly precise zonation. Buchia mosquensis (Von Buch) and B. rugosa (Fischer), characteristic of the Kimmeridgian and early Tithonian Stages, are found in the highest beds north of the Brooks Range. Strata of latest Tithonian age are found along Joe Creek where they contain Buchia fischeriana (d'Orbigny) and B. unschensis. These beds disconformably overlie the Shublik Formation and indicate a Late Jurassic marine incursion.

We collected many microfossil samples from measured sections of the Kingak Shale. Most are closely tied to ammonites and pelecypods, and in general the age as determined from the microfauna correlates fairly well with that obtained from the megafauna.

All 43 samples collected from the dark fissile clay shale, dated as Early Jurassic from a sparse megafauna, are barren. In general this is in keeping with the scarcity of megafaunal remains in these same beds. Apparently the Early Jurassic seas in northeastern Alaska were not ecologically suited to a large biomass.

A rapid expansion of both micro- and megafauna occurred at the beginning of the Bajocian Stage (Middle Jurassic), and continued throughout the remainder of Jurassic time. A total of 95 samples were collected, about 80 percent of which contained microfossils. The microfossils obtained from the reference section in Ignek Valley are listed in table 1.

The reference section of Kingak Shale in Ignek Valley is one of the few exposed sections of Jurassic rocks in northeastern Alaska that contains both a mega- and microfauna that is well developed and diversified. The megafauna consists of ammonites and pelecypods that are known to have restricted stratigraphic range and worldwide distribution in the boreal region. Presumably the microfauna also should show these properties, but it does not. Bergquist states (written commun., 1972):

\footnotetext{
$* * *$ Despite the large assemblage, however, the foraminifera in general are not particularly useful in delimiting stages of the Jurassic because many are long ranging or they appear in beds that are older or younger than those from which they were described. Most of the arenaceous forms range throughout the entire section although some were originally described from the Lower Jurassic (ToarcianPliensbachian) beds of northern Alaska and had been considered indicative of rocks of Early Jurassic age, and some species which were
}

described from beds of Late Jurassic age occur only in older beds in this section. The range or occurrence of some of the calcareous forms also seems erratic and many species occur in beds younger than those from which they were described. This apparent age discrepancy may be due to the fact that previously we have not had completely sampled sections of Middle and Upper Jurassic rocks which provided diagnostic megafossils and foraminifera with which to compare the known Jurassic faunas.

There is no ready explanation for the apparently unrestricted range of many of the Foraminifera in the Ignek Valley section, other than the fact that they occur through a longer interval than originally suspected. If it were only a matter of older forms occurring in younger beds, it could be explained by cannibalization and reworking of older beds into younger deposits, but the presence of presumed Late Jurassic forms in Middle Jurassic beds cannot be explained as easily. Apparently a reevaluation of the published age assignment of the Foraminifera for the Jurassic of northern Alaska is in order.

One possible correlation can be made in the Foraminifera from the Ignek Valley reference section. Rectoglandulina quinquecostata Bornemann from the base of unit 5 and top of unit 6 is known to occur, in northern Alaska and Germany, only in the Toarcian Stage. In Ignek Valley it underlies Inoceramus lucifer of Bajocian age and may indicate that the dark clay shale at the base of that section is Early Jurassic.

\section{IGNEK FORMATION (ABANDONED)}

Leffingwell (1919, p. 120) applied the name Ignek Formation to a series of dark shales with coal of "red beds" and subordinate sandstones. He considered these rocks, which overlie the Kingak Shale, to be Jurassic(?), and the youngest Mesozoic unit in northeastern Alaska. The type locality is on the south side of Red Hill in Ignek Valley, at the west end of the Sadlerochit Mountains, where about $800 \mathrm{~m}(2,600 \mathrm{ft})$ of beds are exposed along the north bank of Ignek Creek. Subsequent investigations be Gryc and Mangus (1947) and Keller, Morris and Detterman (1961) determined that the formation included both Lower and Upper Cretaceous beds. Keller, Morris, and Detterman redefined the Ignek (p. 203) to include only those rocks that were the lithologic equivalent of the Nanushuk and Colville Groups, and placed the lowest Cretaceous beds in the Okpikruak Formation, which included the basal Kemik Sandstone Member. The sandstone along the west side of Canning River, near Shublik Springs, was considered by them to be the lower part of the Ignek Formation. We consider these beds to be the Kemik Sandstone Member. The upper part of the type section of the Ignek Formation is now considered the Seabee Formation, and the lower part the Kongekut Formation.

During the recent investigations we studied many more sections of Cretaceous rocks in northeastern Alas- 
ka. As a result we determined that some of these rocks so closely resemble formations and members of the Nanushuk and Colville Groups that these stratigraphic units should be extended into northeastern Alaska. To avoid further confusion, we here abandon the term Ignek Formation.

\section{OKPIKRUAK FORMATION (GEOGRAPHICALLY RESTRICTED)}

The Okpikruak Formation was named by Gryc, Patton, and Payne (1951, p. 159) for a flyschlike sequence of rhythmically bedded fine-grained greenish-gray graywacke, dark clay shale, and siltstone exposed along a small tributary of the Okpikruak River, about $320 \mathrm{~km}$ $(200 \mathrm{mi})$ west of the report area. Keller, Morris and Detterman $(1961$, p. 195) extended the formation into northeastern Alaska and defined the Kemik Sandstone Member at the base.

Our -recent field investigations in northeastern Alaska have revealed that the lithology of the Neocomian rocks exposed there is dissimilar to the Okpikruak Formation in its type area. Consequently, we here abandon the use of this stratigraphic term in northeaste.n Alaska, and restrict its use to those rocks in the central and western parts of northern Alaska that are lithologically similar to its type locality. The Neocomian strata in northeastern Alaska are in part coeval with the Okpikruak, but a new stratigraphic term, Kongakut Formation, is herein introduced to describe these rocks. The Kemik Sandstone Member is retained as a member of the new formation.

\section{KONGAKUT FORMATION}

Name and distribution.-The name Kongakut Formation is here applied to a thick Lower Cretaceous shale and siltstone sequence that contains a sandstone unit near the base. The formation is divided into three informal members and one named member. In ascending stratigraphic order they are: clay shale, Kemik Sandstone, pebble shale, and siltstone members.

The rocks are well exposed in the upper Kongakut River area after which the formation is named, particularly along both flanks of Bathtub Ridge. The exposures along Bathtub Ridge contain the only complete section of the formation within the northeastern Brooks Range, although a partial section is exposed along Joe Creek. A section of similar strata is exposed at Atigun Gorge, 80 $\mathrm{km}(50 \mathrm{mi})$ southwest of the map area.

The formation is present north of the Brooks Range in a fairly broad belt of low relief that is broken by a series of persistent east-west hogback ridges formed of the Kemik Sandstone. Part of this belt was originally mapped as Okpikruak Formation by Keller, Morris, and Detterman (1961, pl. 21), but the rocks have little in common with the type Okpikruak and are now included with the Kongakut Formation; the Kemik Sandstone Member is retained, however, as it was named for the sandstone present on Kemik Creek. The strata are exposed as far east as the Aichilik River and are probably present east of the Aichilik, covered by surficial deposits. Similar beds have been mapped in the adjoining Yukon Territory (Norris, 1972).

Thickness and stratigraphic relations. - The type section for the Kongakut Formation is $637 \mathrm{~m}(2,090 \mathrm{ft})$ thick on the north flank of Bathtub ridge $15.8 \mathrm{~km}(9.2$ mi) S. $85^{\circ} \mathrm{W}$. of the mouth of Cottonwood Creek, lat $69^{\circ} 06^{\prime} 30^{\prime \prime} \mathrm{N}$., long $142^{\circ} 17^{\prime} \mathrm{W}$. (fig. 2, loc. 10). At the type section the basal clay shale is about $107 \mathrm{~m}$ ( $350 \mathrm{ft})$ thick, the overlying Kemik Sandstone Member about $80 \mathrm{~m}$ $(260 \mathrm{ft})$, the pebble shale $160 \mathrm{~m}(520 \mathrm{ft})$, and the siltstone is $290 \mathrm{~m} \mathrm{(960} \mathrm{ft)} \mathrm{thick;} \mathrm{this} \mathrm{is} \mathrm{the} \mathrm{maximum} \mathrm{measured}$ thickness for the formation. A section $220 \mathrm{~m}(720 \mathrm{ft})$ thick was measured at Kemik Creek. Another section $90 \mathrm{~m}$ (300 ft) thick, measured on the south side of Ignek Valley (fig. 2, loc. 11), is considered a reference section.

At its type area, the Kongakut Formation unconformably overlies the Ivishak Formation of the Sadlerochit Group. The actual contact is not exposed, but the covered interval is only about $20 \mathrm{~m}(70 \mathrm{ft})$ thick where the section was measured, with no indication of either the Shublik Formation or the Kingak Shale; shale float in the covered interval is similar to the Kongakut. Both of these stratigraphic units underlie the formation along Joe Creek about $50 \mathrm{~km}(30 \mathrm{mi})$ southeast of this area. North of the Brooks Range the contact relationship with the underlying Kingak Shale is not known defiitely, but fauna obtained from the Kingak at several localities near the contact suggest a disconformity. Locally along the north side of the Sadlerochit Mountains the Kongakut is unconformable on the Ivishak Formation.

Several unconformities are present locally within the Kongakut Formation, primarily north of the Brooks Range, but the contacts between members appear conformable and gradational at the type locality. The Kemik Sandstone Member is the basal unit of the formation in most areas north of the Brooks range. Locally the pebble shale member has cut out both the Kemik and underlying clay shale and rests unconformably on rocks from the Kingak Shale to the Ivishak Formation; this break is probably the major Early Cretaceous unconformity in northern Alaska and is present both at the surface and in the subsurface (Fackler and others, 1971; Mangus and Pessel, 1972).

In areas where the Bathtub Graywacke normally succeeds the Kongakut, as it does at the type locality, the contact between the two units appears structurally conformable. However, the graywacke represents the ini- 
TABLE 1.-Foraminifera distribution chart for the [Number of specimens 1-5; R, rare (6-11); C, common

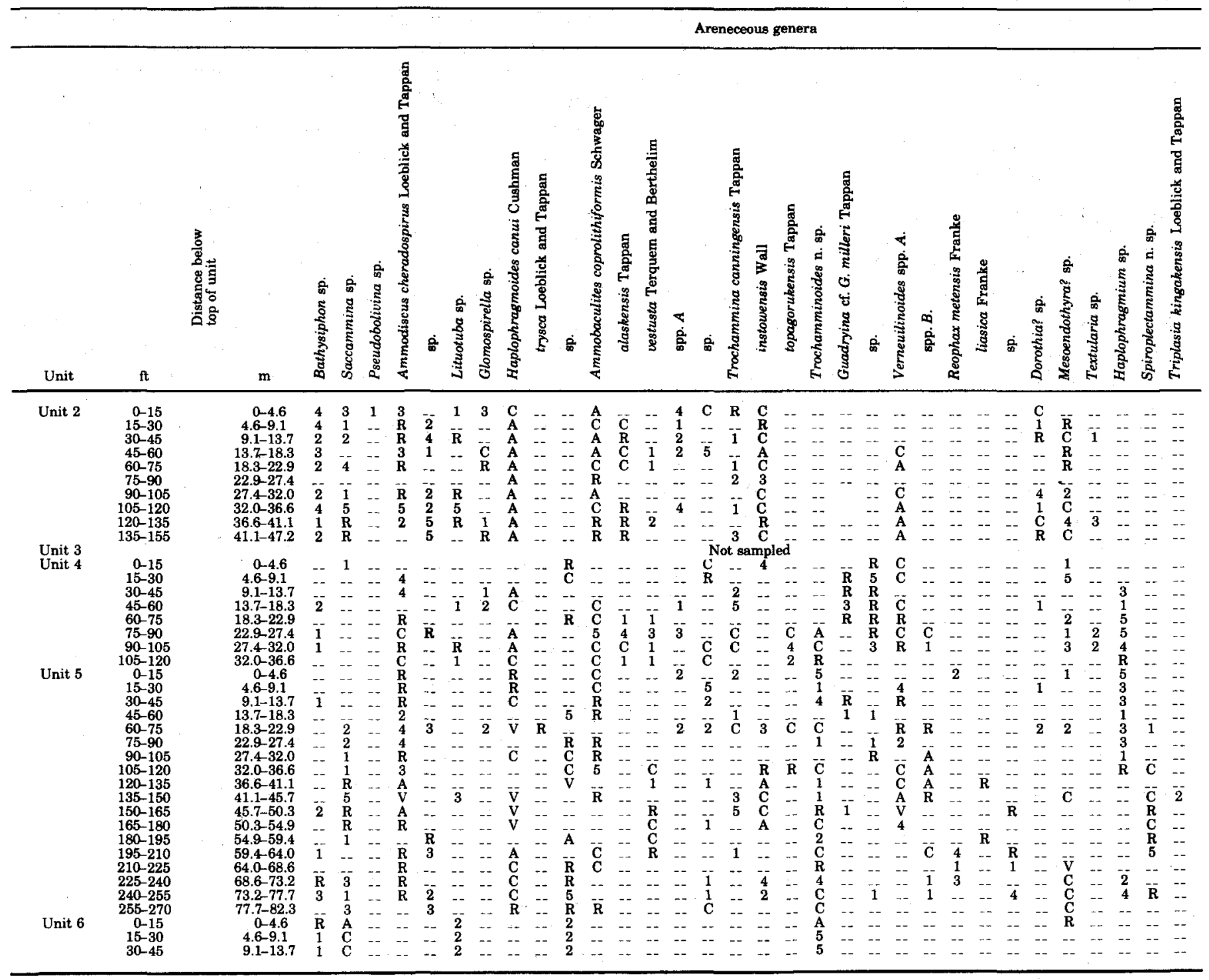

tial deposit from a new provenance of sediments, and the contact is considered a disconformity. Elsewhere, the Kongakut is overlain unconformably by the Nanushuk Group (late Early Cretaceous) and Colville Group (Late Cretaceous).

Lithology. - The Kongakut Formation is dominantly shale and siltstone, with minor amounts of sandstone. The sandstone is commonly a very fine to fine-grained quartz arenite. With the exception of the flattened, highly polished chert pebbles in the pebble shale member, the sandstone is the coarsest clastic rock in the formation.

The clay shale member at the base of the Kongakut is a nonresistant saddle-forming unit about $110 \mathrm{~m}$ (350 ft) thick (fig. 8); it is a dark-gray, soft, fissile rock that is poorly exposed at most localities. Clay ironstone nodules are common, and several thin arenaceous bioclastic limestone beds are present in upper and lower parts of the unit. The lower limestone is a coquinite of Buchia sublaevis shells.

The overlying Kemik Sandstone Member is mainly a very fine grained quartz arenite that forms resistant ledges on hill slopes at the type locality. In thin section most grains are 0.07 to $0.125 \mathrm{~mm}$ in diamter, and about 85 percent are well-rounded, tightly packed quartz and chert. Minor amounts of glauconite, phosphate, sericite, and zircon are present, along with some secondary calcite. Black organic material borders some mineral grains.

North of the Brooks Range the Kemik Sandstone 
Member is mainly a fine-grained, medium- to heavybedded, lenticular subfeldspathic quartz arenite in the upper part and a feldspathic wacke in the lower part. The upper beds are clean, with tightly packed solution-welded grains primarily of quartz and tripolitic chert. The lower 4.5 to $6 \mathrm{~m}$ (15 to $20 \mathrm{ft}$ ) contains abundant sericitic clay, chlorite, phosphate, and carbonaceous material along with 10 to 15 percent feldspar and thin stringers of chert- and quartz-pebble conglomerate. The white tripolitic chalky chert is characteristic of the entire Kemik section, mainly as small grains giving the rock a mottled appearance. Thin sections show that these grains are almost completely disintegrated chert. Limonite staining is common throughout the Kemik section, and several 15 to $30 \mathrm{~cm}$ (6-in to 1-ft) beds in the lower part of the section are stained bright orange.

The Kuparuk River Sand (Basye, 1969; Rickwood, 1970; Fackler and others, 1971) of the subsurface occupies the same stratigraphic position as the Kemik Sandstone Member in the surface exposures. The lithologic character of the two units is also similar and they are considered correlative, although this assumption cannot be definitely proved at present.

The pebble shale, perhaps the most distinctive unit of the formation, is about $160 \mathrm{~m}(520 \mathrm{ft})$ thick and contains approximately $50 \mathrm{~m}(175 \mathrm{ft})$ of highly manganiferous beds in the middle of the section. These beds are resistant to erosion, but the remainder of the section forms saddles. The manganiferous beds are uniformly black, 
LITHOLOGIC SYMBOLS

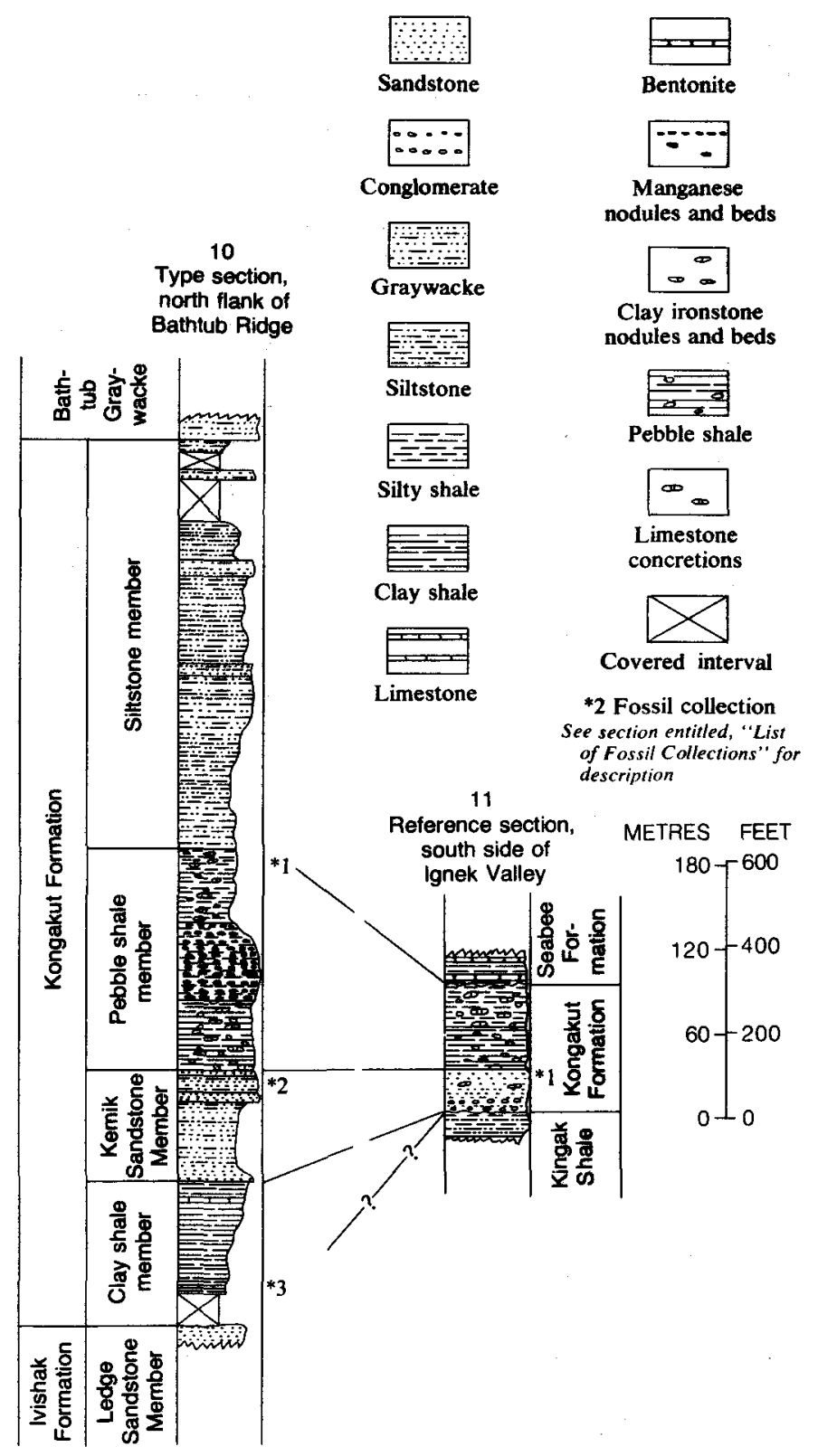

FIGURE 8.-Type and reference sections for the Kongakut Formation.

with small pellets and thin beds of manganese carbonates. Analyses of a few samples indicate a manganese content of about 5 percent. The manganese is a sedimentary manganese carbonate, but the exact chemical composition is unknown. Small amounts of lead and copper are also present, and a few beds are stained blue from the copper. Flattened, highly polished chert pebbles as much as $2.5 \mathrm{~cm}$ ( 1 in.) in diameter are found through most of the section. These same beds contain a few well-rounded quartz grains 0.03 to $0.05 \mathrm{~mm}$ in diameter. The rocks are similar in many respects to the pebble shale of the subsurface (Fackler and others, 1971), but the subsurface unit does not contain the manganese characteristic of this member of the Kongakut Formation and it contains a distinctive gamma-ray horizon. Clay ironstone nodules are common throughout all but the highly manganiferous part of this shale.

The siltstone member at the top of the Kongakut is about $290 \mathrm{~m}(960 \mathrm{ft})$ thick and contains a few intercalated sandstone beds that form prominent ledges. The sandstones are fairly clean, in contrast to the massively bedded graywacke that overlies the Kongakut. The upper contact is placed at the base of the lowest massive graywacke bed.

The Kongakut Formation contains a remarkable array of sedimentary features that are generally attributed to turbidity-current deposition in deep water. These include flute and load casts, skip, drag, and brush marks, as well as flame and ball-and-pillow structures. Most of these features are commonly formed by density currents flowing down a submarine slope in moderately deep water (Potter and Pettijohn, 1963,p. 114-139). The lighology of the formation would tend to support this view, although Rucklin (1938) has shown experimentally that some of these marks can be formed by eddy currents in shallow water.

The megafauna provides additional evidence for the depositional environment of the formation. In the lower part of the Kongakut, arenaceous limestone coquinite beds composed of the pelecypod Buchia were clearly deposited in shallow water. According to Imlay (1959, p. 156) Buchia preferred a hard substratum on which to attach themselves in shallow, agitated water. These conditions could be satisfied by a shallow transgressing Early Cretaceous sea, which would also explain the unconformity between the Kongakut Formation and the underlying rocks. The fauna from the Kemik Sandstone Member is also characteristic of the neritic zone. The facies-controlled pelecypod fauna in other units north of the Brooks Range is also indicative of the shallow neritic zone.

The pebble shale has little fauna to offer as an indicator of depositional site, except perhaps that the general lack of fossils may indicate an inhospitable deepwater environment. The abundance of manganese nodules and beds may also suggest deep water, but a similar condition could exist in a starved shallow-water basin. The general lack of faunal indicators, coupled with the character of the sediments, would suggest deepwater deposition for the pebble shale member, but the evidence is not conclusive. The siltstone member probably marks a return to shallow-water conditions.

Age. - The sparse megafauna in the lower part of the section indicates that the Kongakut Formation is Early Cretaceous (Neocomian) in age. No fossils have been found in the upper part. The Buchia coquinite beds 
about $30 \mathrm{~m}$ (100 ft) above the base of the clay shale member contain only one species, Buchia sublaevis Keyserling of early Valanginian age (Imlay, 1959). The Berriasian Stage is not represented by megafossils at the type locality, but the diagnostic Buchia okensis Pavlow and B. subokensis Pavlow are present on Kemik Creek.

The upper part of the Kemik Sandstone Member at Bathtub Ridge has a sparse megafauna consisting of ammonites, pelecypods, and belemnites. The Hauterivian ammonite Simbirskites sp., in its first reported occurrence in northern Alaska, places a lower age limit on the overlying pebble shale member. North of the Brooks Range the Kemik contains a facies-controlled pelecypod fauna slightly different from that found at the section on the upper Kongakut. This fauna is characterized by Astarte ignekensis Imlay, originally believed to be of middle Albian age (Imlay, 1961, pl. 24), but the presence of Simbirskites sp. in the sandstone at Bathtub Ridge indicates the fauna also extends down into the Neocomian beds.

The pebble shale member has only a few poorly preserved pelecypods that are provisionally identified as Aucellina(?) sp. This identification, if correct, would indicate a possible Aptian to Albian age for these beds, which are a widespread horizon marker in both surface and subsurface. Primarily on the basis of lithology, these beds are more likely to be Neocomian than Aptian. However, a persistent and widespread Lower Cretaceous unconformity is present in many parts of northern Alaska at the base of this pebble shale. The overlying siltstone member and Bathtub Graywacke have produced no datable fossils. A minimum age for the pebble shale is delimited, however, by the presence of Paragastroplites spiekeri (McLearn) of middle Albian age in overlying strata on Arctic Creek.

Many of the microfossil samples from the Kongakut Formation are barren. The upper $152 \mathrm{~m}(500 \mathrm{ft})$ of the siltstone member has produced no microfossils, but a sparse fauna from the underlying beds helps determine their age. The fossiliferous samples are listed in table 2 . Sample 70ADt-209, unit 1, number 25 is of considerable interest; it contains a diversified fauna including Glomospirella arctica Chamney, Bathysiphon scintillata Chamney, Ammodiscus mackenziensis Chamney, Haplophragmoides goodenoughensis Chamney, and Ammobaculites reophacoides Chamney. According to Bergquist (written commun., 1972) these fossils are characteristic of the Barremian rocks of the Richardson Mountains in the adjoining Yukon Territory, Canada. A few specimens of Gaudryina richteri Grabert were also found in this sample; this is an upper Hauterivian fossil according to Bergquist. This microfauna supports the age as determined from the megafauna and permits a more precise assignment for the pebble shale member. A feature of some importance in interpreting the microfauna is the presence of a Jurassic-to-Cretaceous transition or mixed phase at the base of many sections. The characteristic Late Jurassic fauna includes $A m$ mobaculites coprolithiformis, Haplophragmoides canui, Gaudryina milleri, and Reophax metensis. Associated with these Foraminifera are the typical Early Cretaceous Haplophragmoides topagorukensis, Gaudryina tailleuri, Bathysiphon brosgéi, and B. vitta.

The existence of a transition or mixed zone at the base of the Kongakut Formation may help to solve some problems of correlation in northern Alaska resulting from age interpretations based on microfauna as opposed to megafauna. Bergquist (1966, p. 100) alluded to the problem of a Late Jurassic microfauna associated with Early Cretaceous Buchias at Kemik Creek; this condition is now known to occur at numerous localities. The key to the solution is the combination of the two microfaunas. The reason the faunas are mixed is not entirely clear. An obvious reason is that Jurassic rocks were reworked in the Cretaceous, and this probably is a prime factor. However, another possible cause is that certain Foraminifers were designated Jurassic or Cretaceous, when in reality they occurred in beds with poor stratigraphic control. Finally, the Jurassic forms may actually have a longer range than originally thought.

\section{BATHTUB GRAYWACKE}

Name and distribution.-The name Bathtub Graywacke is here applied to a thick sequence of graywacke and conglomerate with siltstone and shale interbeds that is exposed along Bathtub Ridge in the upper Kongakut River area (fig. 2, loc. 12). The type section is about $0.8 \mathrm{~km}(1 / 2 \mathrm{mi})$ west of the type section for the Kongakut Formation, on the north flank of Bathtub Ridge, lat $69^{\circ} 05^{\prime} 30^{\prime \prime}$ to $69^{\circ} 06^{\prime} 15^{\prime \prime} \mathrm{N}$., long $142^{\circ} 18^{\prime} \mathrm{W}$. (fig. 2, loc. 12). The Kongakut is commonly exposed with the Bathtub Graywacke at many localities. Bathtub Ridge is approximately $30 \mathrm{~km}$ (20 mi) long, and the upper resistant part of the ridge is entirely formed of this graywacke and conglomerate.

North of the Brooks Range the graywacke is exposed in a broad belt of discontinuous outcrops between the Okpilak and Okerokovik Rivers. A series of outcrops along Sabbath Creek, an eastern tributary of the Jago River, lat $69^{\circ} 37^{\prime}$ to $69^{\circ} 41^{\prime} \mathrm{N}$., long $143^{\circ} 30^{\prime}$ to $143^{\circ} 33^{\prime} \mathrm{W}$., exposes a thick sequence of graywacke, conglomerate, siltstone, and shale; this is considered a reference section of the Bathtub Graywacke (fig. 2, loc. 13, and fig. 9).

Thickness and stratigraphic relations.-The best exposed sections of the formation are in the type area along the north flank of Bathtub Ridge, where up to 750 $\mathrm{m}(2,460 \mathrm{ft})$ is exposed. The section there is incomplete, 
however, so the actual thickness may be closer to the $1,300 \mathrm{~m}(4,250 \mathrm{ft})$ present along Sabbath Creek, north of the Brooks Range.

The lower contact with the Kongakut Formation appears to be conformable; it is placed at the base of the lowest massive graywacke. A few thin graywacke beds are present in the underlying siltstone member of the Kongakut, so the contact is probably gradational.

The Bathtub Graywacke is overlain by the Tuktu
Formation of the Nanushuk Group along Sabbath Creek and at several other localities east of the Okpilak River. The actual contact was covered, but the beds above and below appear structurally conformable. However, the Tuktu Formation overlies the pebble shale member of the Kongakut Formation west of the Hulahula Riber, so the upper contact is at least locally unconformable.

Lithology. - The Bathtub Graywacke consists

TABLE 2.-Foraminifera distribution [ $\mathrm{R}=$ rare (1-10); $\mathrm{C}=$ common (11-25); $\mathrm{A}=$

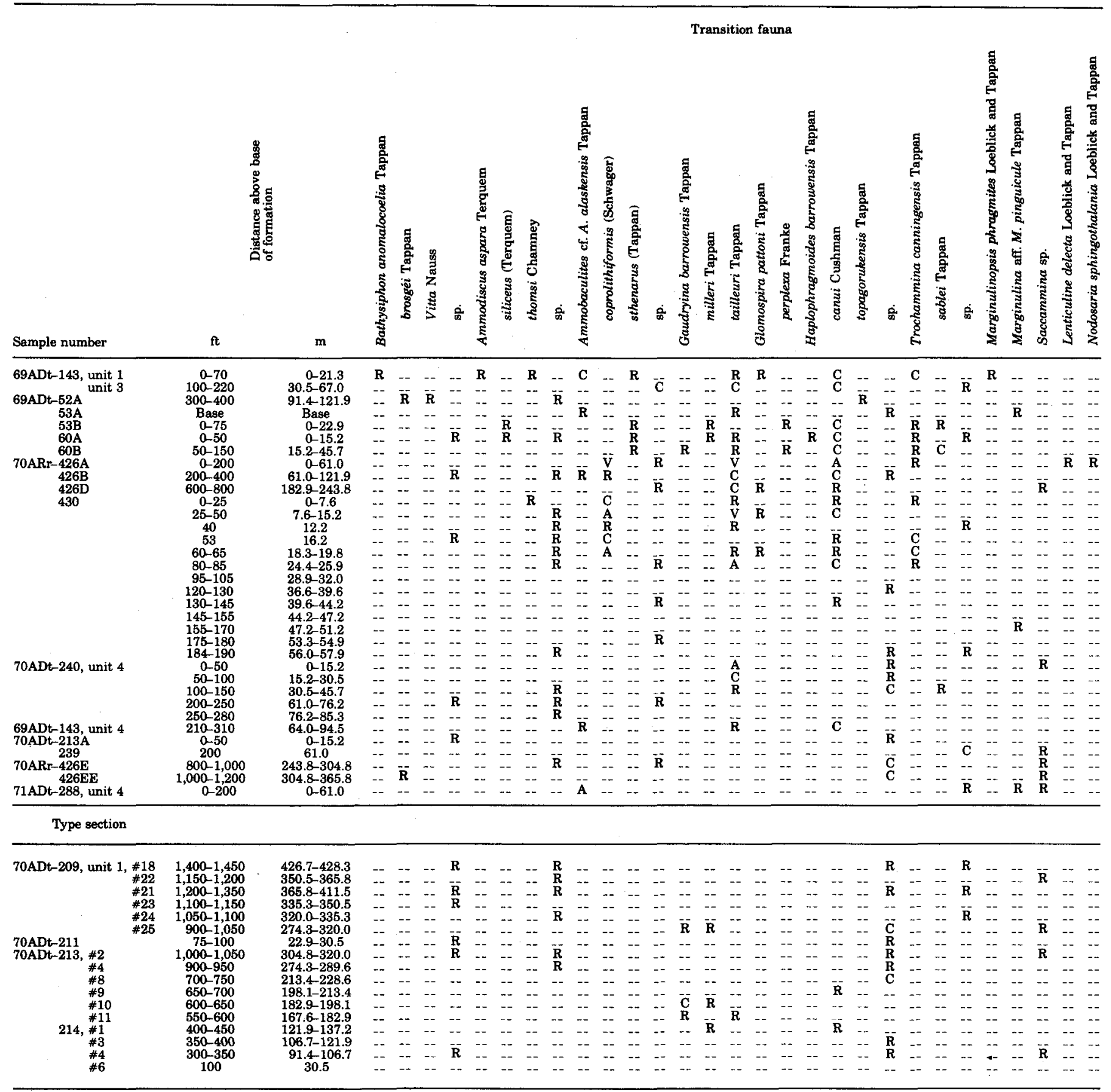


mainly of subfeldspathic lithic graywacke (Williams and others, 1958, p. 302) with interbeds of siltstone, shale, and conglomerate. The conglomerate primarily black chert, is a major constituent only at the reference locality, although similar conglomerate and pebbly sandstone beds are present in the type area.

The graywacke is a dark-grayish to green rock, fine to coarse grained, and thin to massively bedded. Small angular lithic fragments are a common feature of many beds. Some of the units are crossbedded and others are graded. Flute and load casts are common on the thinbedded fine-grained graywacke. The overall depositional pattern of the Bathtub Graywacke is cyclic, with units of siltstone and shale following each major unit of graywacke or conglomerate. The duration of each cycle became shorter as time progressed, probably in response to increased orogenic activity in the source area.

chart for Kongakut Formation

abundant (26-50); V = very abundant (>50)]

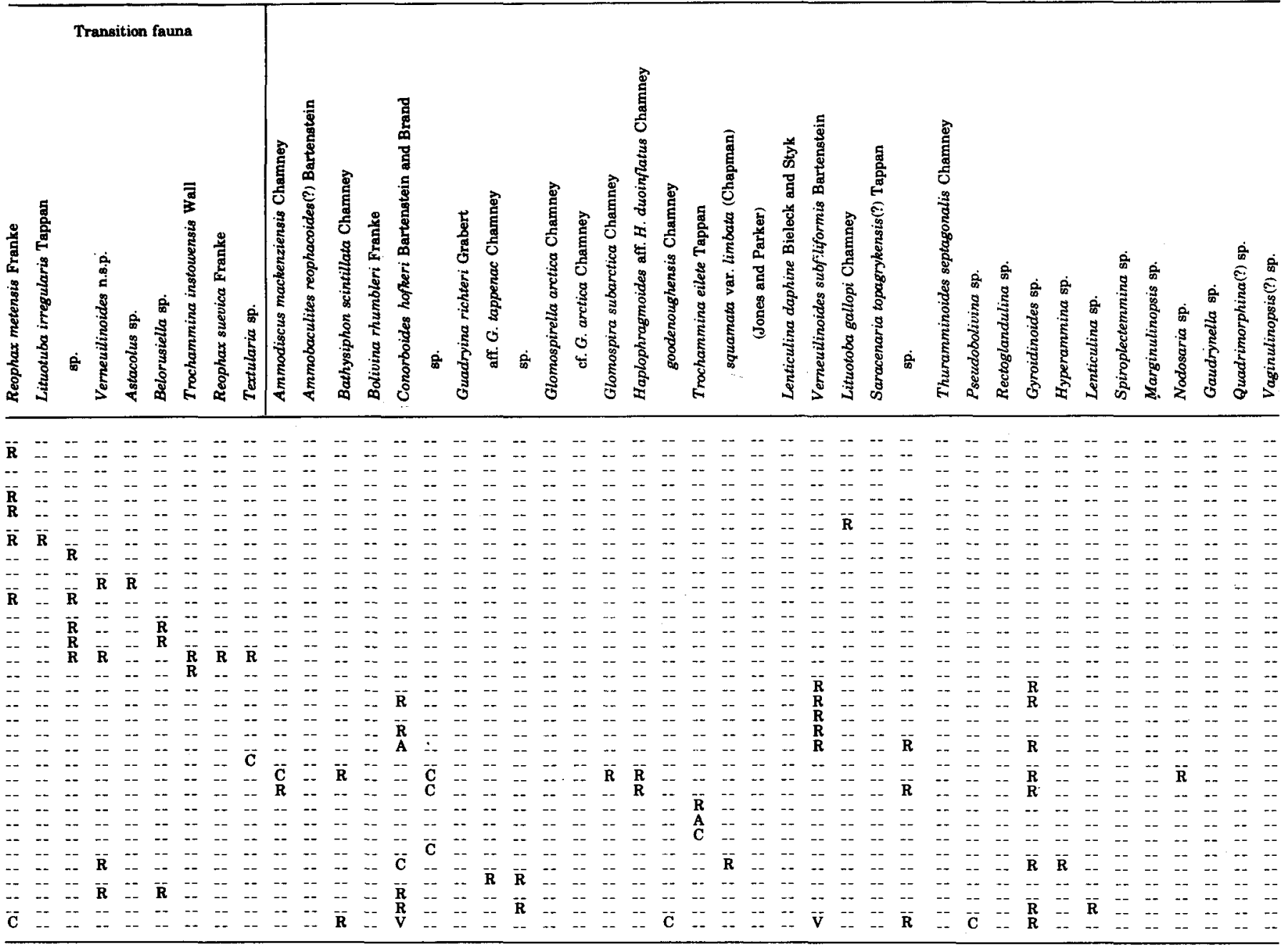

Type section

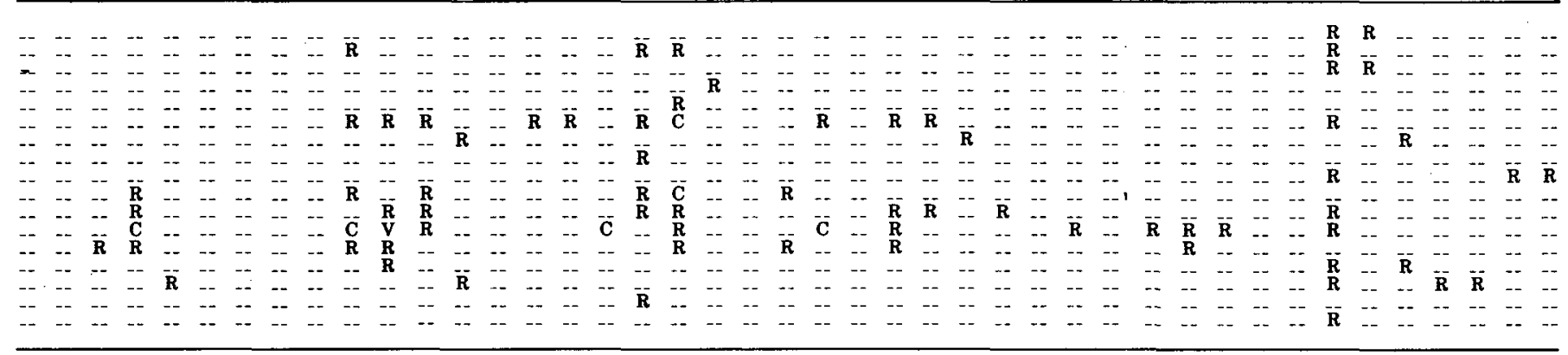


Thin sections show that lithic clasts, consisting of chert, quartzite, phyllite, slate, shale, and siltstone, form 40 to 70 percent of the rock. Most are subround to round with little size sorting. Subangular quartz is the only primary mineral grain of major importance. The feldspar content is generally no more than 5 to 10 percent of the total rock; this probably reflects a source area in the Brooks Range, an area of relatively few igneous rocks. The matrix is mainly sericitic clay and chlorite. A few beds contain minor amounts of secondary calcite, but calcareous cement is rather uncommon for these rocks. Isotropic, well-rounded grains of phosphate are present in most thin sections, which suggests that beds at least as young as the Shublik Formation were being eroded and reworked. Plant debris is common, particu-

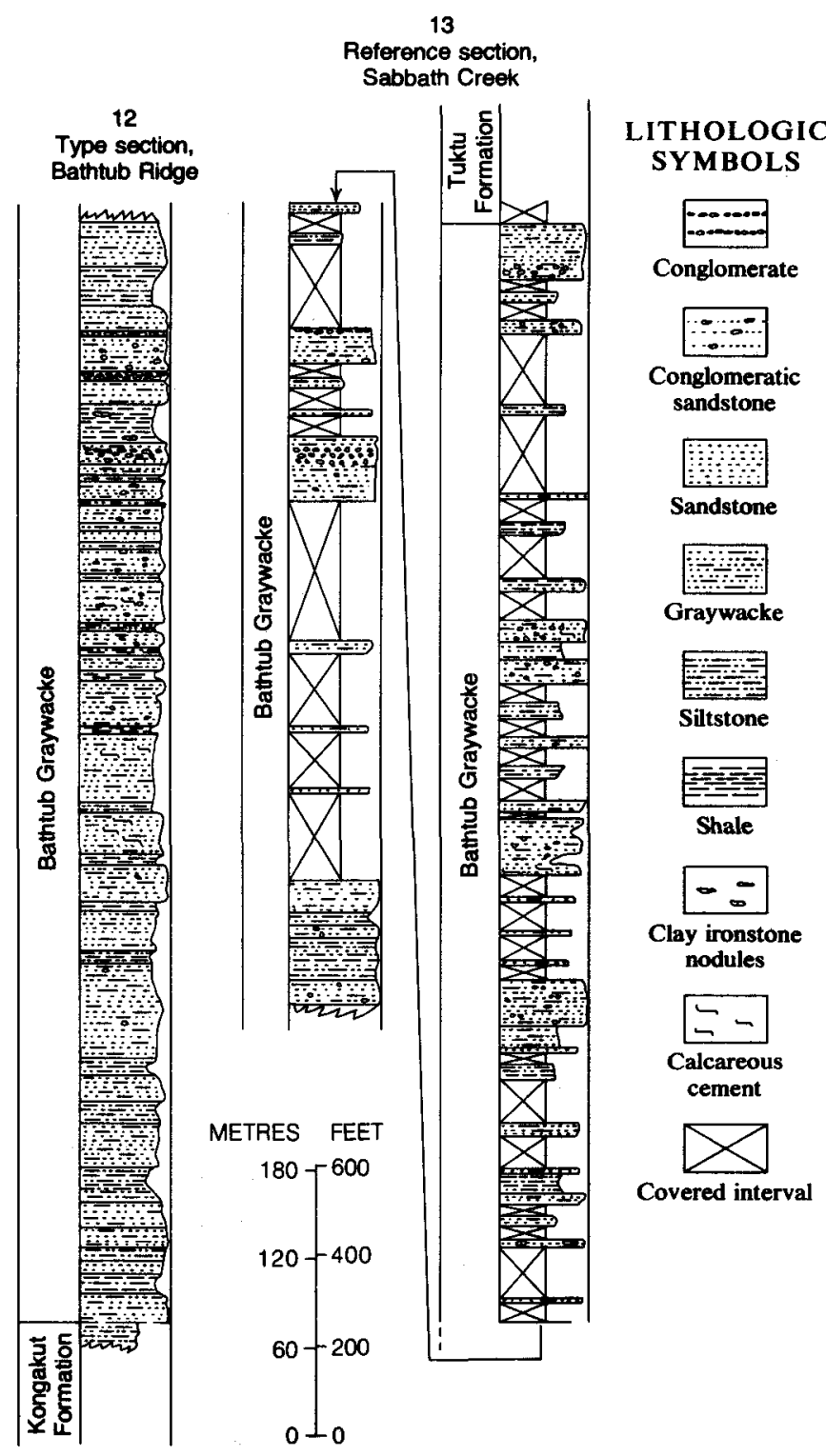

Figure 9.-Type and reference sections for the Bathtub Graywacke. larly at the reference locality, where many stems and twigs are present. Carbonaceous material occurs in all thin sections.

The provenance of sediments for the Bathtub Graywacke was clearly south in the ancestral Brooks Range; this is based on directional sedimentary features and greater thicknesses of sandstone (graywacke) in the southern exposures. The character of these beds is entirely different from any of the older Mesozoic sandstones. The older sandy beds are quartz arenites, whereas the Bathtub is primarily graywacke. Lithic clasts in the graywacke and conglomerate suggest that some of the older Mesozoic rocks were being eroded and included in the Bathtub sediments. The source of some older Cretaceous rocks may have been to the south, also, but the Bathtub Graywacke is the first unit that we can definitely prove to have had a southern source area.

Age.-The age of the Bathtub Graywacke is not known directly from fossils. Invertebrate remains have not been located in these beds, and plant fossils collected for paleobotanical identification gave disappointing results. According to J. A. Wolfe (written commun., 1971), the only identifiable material was Equisetum, which is long ranging and of little use for age determinations. The pollen and spore samples produced similar results. They were examined by R. A. Scott, who states (written commun., 1972) that a few fragments of the marine alga Tytthodiscus were found. This is common in Upper Jurassic and Lower Cretaceous rocks of northern Alaska. In addition a few reworked spores of Devonian age were identified. All samples collected for Foraminifera were barren.

The age of these beds can be determined fairly accurately, however, from faunal remains in the underlying and overlying beds. The underlying Kongakut Formation is at least as young as Hauterivian, on the basis of ammonites, and may be as young as Barremian, as suggested by Foraminifera. One poor collection of pelecypods from the Kongakut pebble shale was identified by D. L. Jones (written commun., 1972) as Aucellina? sp. This would suggest that beds underlying the Bathtub were as young as Aptian. Although the Aptian Stage has never been positively identified in northern Alaska, it is present a short distance to the east, in northern Canada (Norris, 1972). The overlying Tuktu Formation contains ammonites of middle Albian age, so the Bathtub Graywacke probably represents an early Albian deposit that is at least in part equivalent to the Fortress Mountain Formation of Central Alaska.

\section{NANUSHUK GROUP}

The Nanushuk Group was defined by Gryc, Patton, and Payne (1951) as a sequence of rocks typically ex- 
posed in the central part of the northern foothills about $240 \mathrm{~km}(150 \mathrm{mi})$ west of this report area. These rocks have been subdivided and redefined several times since then (Gryc and others, 1956; Detterman and others, 1963). The group contains both marine and nonmarine formations that are mapped along the Sagavanirktok and Ivishak Rivers (Keller and others, 1961). Recent investigations in northeastern Alaska have shown that rocks included in the lower part of the Ignek Formation in the western Sadlerochit Mountains are better considered part of the Nanushuk Group, and the term is here extended into that area.

A few small rubble exposures west of the Kavik River are mapped as "Nanushuk Group undivided" (Reiser and others, 1971). A fairly thick sequence of the Nanushuk Group is exposed south and east of the Sadlerochit Mountains. These rocks can be identified as part of the Tuktu and Chandler Formations. The Nanushuk Group is missing north and northwest of the Sadlerochit Mountains. This area was a structural high during Triassic to Neocomian time, and the Nanushuk may never have been deposited there. If deposited, it was eroded away before the Colville Group was deposited.

$$
\text { TUKTU FORMATION }
$$

Name and distribution.-The Tuktu Formation was originally defined as a member of the Umiat Formation by Gryc, Patton, and Payne (1951) and later raised to a formation within the Nanushuk Group by Detterman (1956a). Its type locality was established at Tuktu Bluffs on the Chandler River. Rocks that are considered correlative with this formation are best exposed in the area between the east end of the Sadlerochit Mountains and the Okerokovik River. One reference section (fig. 2, loc. 14) is well exposed along Arctic Creek, lat $69^{\circ} 27^{\prime} 30^{\prime \prime}$ to $69^{\circ} 30^{\prime} \mathrm{N}$., long $144^{\circ} 30^{\prime}$ to $144^{\circ} 34^{\prime}$ W. Another reference section was measured along Sabbath Creek (fig. 2, loc. 15). Good exposures are present, also, along the Kekiktuk and Hulahula Rivers, and small ridgetop rubble traces occur between the Okpilak and Jago Rivers (Reiser and others, 1974).

Thickness and stratigraphic relations. - The reference section for the Tuktu Formation along Arctic Creek is $215 \mathrm{~m}$ (700 ft) thick (fig. 10). At this locality the Tuktu unconformably overlies the pebble shale member of the Kongakut Formation; this is not a complete section as the overlying rocks have been removed by erosion. A more complete section of the formation is present, however, at the reference section on Sabbath Creek, where about $520 \mathrm{~m}(1,700 \mathrm{ft})$ was measured (Fig. 10). A $65-\mathrm{m}$ (220 ft) covered interval separates the Tuktu Formation from the underlying Bathtub Graywacke; this covered interval is here included with the Tuktu for convenience in mapping, thus making the Sabbath Creek section comparable to the thick sections exposed in the Killik-Etivluk region about $450 \mathrm{~km}$ (280 $\mathrm{mi})$ to the west.

The lower contact with the Bathtub Graywacke, while not actually exposed, probably should be considered as a disconformity inasmuch as the Tuktu Formation is known to be unconformable on the Kongakut Formation at Arctic Creek. The Tuktu Sea must therefore have been transgressive across the area. The upper contact with the Chandler Formation is conformable.

Lithology. - The Tuktu Formation is mainly an interbedded sequence of thin-bedded fine-grained greenish-yellow calcareous sandstone, dark siltstone, and shale. Several massive yellowish-brown sandstone units occur at intervals throughout the section. Many of the sandstones on Arctic Creek contain abundant prisms of broken Inoceramus shells; some are almost Inoceramus-prism calcarenite. Sole markings are a diagnostic feature of most of the Tuktu sandstones and siltstones. These are mainly in the form of flute and load casts, although skip and drag marks and flame structures are also present, suggestive of deepwater turbidite deposition. However, the Inoceramus-prism beds would indicate a shallow-water depositional site, and the Sabbath Creek section is extensively crossbedded. In addition, many of the crossbedded sandstones contain lenses and stringers of pebble conglomerate suggestive of shallow-water deposition. These pebbly and conglomeratic beds are very similar to the Tuktu as exposed in the Kurupa and Oolamnagavik Rivers area 386 $\mathrm{km}(240 \mathrm{mi})$ to the west (Chapman and others, 1964).

Several thick beds of shale occur throughout the section on Arctic Creek. Clay ironstone nodules and small limestone concretions are fairly abundant throughout the shale, and mud lumps are common. Carbonaceous material and plant scraps are common at Sabbath Creek. In general the Tuktu Formation in northeastern Alaska is very similar to that in the more northerly and westerly exposures in its type area in the Chandler and Colville Rivers region.

Age.-The Tuktu Formation contains a sparse molluscan fauna, primarily in the sandstones on Arctic Creek. The diagnostic element of this fauna is the ammonite Paragastroplites spiekeri (McLearn), which according to Imlay (1961) is indicative of the middle Albian Stage of the Early Cretaceous. These same beds contain the Inoceramus prisms, and although no complete specimens were found, Inoceramus is fairly common in the Albian beds of the type Tuktu Formation. A few unidentifiable pelecypods and the chaetopod worm Ditrupa cornu Imlay are found in the lower sandstones. Ditrupa is common in the middle and late Albian beds 

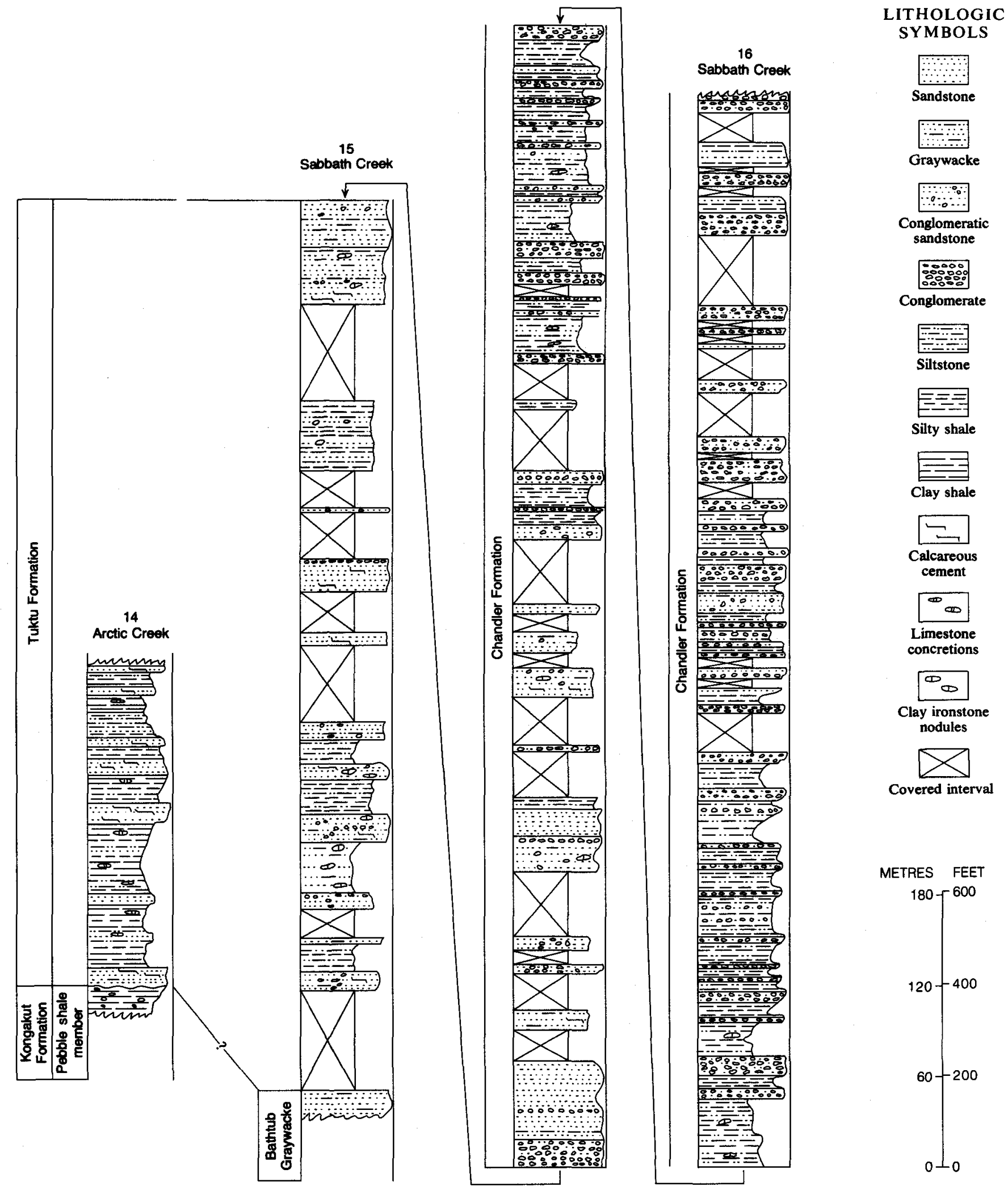

LITHOLOGIC SYMBOLS

Figure 10.-Reference sections for the Tuktu and Chandler Formations. 
farther west, but is also found in Neocomian beds on Arctic Creek.

A few Foraminifera were found in shale samples collected for microfossils along the Sadlerochit River. Two are considered diagnostic of the middle and late Albian Stage: Verneuilinoides borealis Tappan and Trochammina ribstonensis Wickenden subspecies rutherfordi Stelck and Wall. In addition, specimens of Bathysiphon brosgéi Tappan, Glomospirella gaultina (Berthelin), Ammodiscus rotalarius Loeblich and Tappan, and Gaudryina were found. These microfossils are all characteristic of the Tuktu Formation in its type area.

\section{CHANDLER FORMATION}

Name and distribution.-The Chandler Formation was first described by Gryc, Patton, and Payne (1951, p. 164) as the nonmarine formation of the Nanushuk Group. It was subsequently divided into the Killik and Niakogon Tongues (Detterman, 1956a) which, in the type area, grade northward into the marine equivalent of the Chandler.

In northeastern Alaska, the Chandler Formation is confined to a small area between the lower Okpilak River and the Okerokovik River. A good section exposed along Sabbath Creek (fig. 2, loc. 16) is considered a reference section for northeastern Alaska, and was the only section investigated in detail. The rocks are mapped as Chandler Formation, undivided. Both tongues of the formation may be present, but bentoninte characteristic of the Niakogon Tongue was not seen along Sabbath Creek, and the rocks are more typical of the Killik Tongue.

Thickness and stratigraphic relations. - The Chandler is $1,456 \mathrm{~m}(4,775 \mathrm{ft})$ thick at the reference section on Sabbath Creek (fig. 10). This is somewhat thicker than at the type area but not unusually so. Northeastern Alaska represents a basin of deposition that probably was separated from the area to the west, so the general character and thickness could be expected to be somewhat different. In general, however, there is good correlation between the two areas.

The Chandler Formation conformably overlies the Tuktu Formation at the reference section. The contact is placed at the base of a massive pebble-cobble conglomerate with fairly abundant white quartz. Sandstones above the conglomerate are primarily medium- to coarse-grained salt-and-pepper type, in contrast to the fine-grained greenish calcareous rock below the contact. The presence of white quartz clasts in the conglomerate and the salt-and-pepper sandstone are prime characteristics of the Chandler formation in the type area.

The upper contact is not exposed in northeastern Alaska. The Colville Group is present about $16 \mathrm{~km}$ (10 $\mathrm{mi}$ ) to the north and in all probability unconformably overlies the Chandler Formation.

Lithology. - The Chandler Formation is entirely nonmarine in northeastern Alaska. The Grandstand and Ninuluk Formations, the marine equivalents of the Chandler, have not been identified but presumably may be present in the subsurface near the north coast.

Cyclic deposition of polymictic conglomerate, saltand-pepper sandstone, siltstone, and shale is characteristic of the formation. The rocks contain abundant features indicating fluvial deposition including cutand-fill channels and point-bar-type crossbedding in the sandstones and conglomerates. The coarse clastic rocks are overlain by dark siltstones and silty shale units containing abundant plant debris; these are interpreted as being overbank fluvial deposits.

The polymictic conglomerate consists mainly of varicolored chert, black and gray being the most common colors, white quartz, gray quartzite from the Echooka Formation, limestone derived from both the Lisburne Group and Shublik Formation, and minor amounts of other rock types. Most clasts are well rounded and 1.3 to $5 \mathrm{~cm}(1 / 2$ to $2 \mathrm{in}$.) in diameter, although the size varies from fine granules to $15-\mathrm{cm}$ ( 6 in.) cobbles. Many of the conglomerate beds are lenticular, and cut-and-fill structures are common. Most beds are poorly consolidated, having a matrix of clay and sand, and many show graded bedding.

Sandstone associated with the conglomerate is primarily of the salt-and-pepper type, medium to coarse grained, and massive; it is $40-70$ percent dark lithic fragments, 10-15 percent quartz, 5-10 percent feldspar, and minor accessory minerals in a clay matrix. Sandstone interbedded with siltstone between conglomerate beds is generally thin bedded, fine grained, gray, and slightly calcareous. Mud lumps and ironstone concretions are common in the thin bedded sandstone.

Much of the siltstone and shale is micaceous and carbonaceous and dark-gray to black. Plant debris is abundant in all of these fine clastic rocks, but no coal beds were seen. Coal is a common feature of the Chandler Formation in the type area, but the deposits in northeastern Alaska apparently represent a river flood plain rather than the deltaic coal swamps of the type area.

Age.-No identifiable fossil material was obtained from the Chandler Formation in the area of this report, so the age of the beds cannot be determined directly. The formation is, however, considered to be of middle and late Albian age, because it overlies the early middle Albian Paragastroplites beds of the Tuktu Formation, and because it contains no bentonite or tuff. All Cretaceous strata in northern Alaska of Cenomanian or younger age contain abundant bentonite or tuff as beds 
and lithic fragments; this is also true of the Tertiary strata. Consequently, the Chandler Formation in northeastern Alaska cannot be younger than late $\mathrm{Al}-$ bian.

\section{COLVILLE GROUP}

The Colville Group was originally defined as a "series" by Schrader (1902) for a sequence of rocks exposed along the lower Colville River, about $160 \mathrm{~km}(100 \mathrm{mi})$ west of the report area. These beds were later redefined as the Colville Group by Gryc, Patton, and Payne (1951) and Gryc and others (1956). The group includes the Seabee, Prince Creek, and Schrader Bluff Formations, which were further divided into marine members and nonmarine tongues. The group was mapped only in the central and western parts of northern Alaska. Beds farther east, believed to be in part equivalent, were mapped as the upper part of the Ignek Formation by Keller, Morris, and Detterman (1961). During the recent investigations we have studied many more sections of these rocks, and here extend the term Colville Group into northeastern Alaska. The Ignek Formation is abandoned. The stratigraphic units of the Colville Group can be easily recognized and mapped in the northeast, so the extension of the term into this area is justified, particularly because the Ignek Formation included a heterogeneous assemblage of rocks of several ages.

\section{SEABEE FORMATION}

Name and distribution.-The Seabee Formation was originally defined as a member of the Schrader Bluff Formation by Gryc, Patton, and Payne (1951, p. 166). The member was redefined as a formation by Whittington (1956, p. 246) and further divided into the Shale Wall Member (Detterman and others, 1963, p. 269) and Ayiyak Member (Detterman, 1956b, p. 253). The formation was defined to include all marine strata in the Colville Group below the nonmarine Prince Creek Formation. These rocks include a lower bentonitic clay shale; in part a fissile organic shale (Shale Wall Member), and an upper sandstone and siltstone unit (Ayiyak Member).

The best exposures of the Seabee Formation in northeastern Alaska are in Ignek Valley (fig. 2, loc. 17) and along the north side of the Sadlerochit Mountains. In these areas the formation contains the distinctive "red beds" after which Ignek Valley is named. These highly colored "red beds" are very prominent and can be seen for many miles, particularly the ones near Red Hill. Leffingwell $(1919$, p. 121) considered the beds to be burnt coal. It is now believed that these beds were formed by the oxidation or possibly burning of the highly organic paper shale at the base of the Seabee Formation. This shale, when heated, turns red. The ac- tual source of the heat is not known; it could have been produced by a chemical reaction or by burning of the shale. Similar beds in the Smoking Hills, east of the Alaska-Yukon boundary, in northern Canada give off great clouds of smoke, although no fire is visible.

Other outcrops of the Seabee Formation are found as discontinuous cutbanks along many of the streams in the foothills and in the coastal plains (Reiser and others, 1971 and 1974). Geologic structures on the coastal plains are mainly flanked by low-dipping beds; consequently, the area of outcrop is generally broad. Beds of the Shale Wall Member are poorly consolidated and do not form good exposures except where capped by the overlying sandstone of the Ayiyak Member.

Thickness and stratigraphic relations.-Most exposures of the formation are incomplete and generally covered by rubble and mudflows formed of the weakly consolidated rocks. Consequently, many of the stratigraphic details, as well as possible changes in facies and thickness, are not well understood. One fairly good section of both members was obtained from the south side of Ignek Valley, along Ignek Creek (figs. 2 and 11), where approximately $260 \mathrm{~m}(850 \mathrm{ft})$ of beds are preserved (lat $69^{\circ} 33^{\prime} 30^{\prime \prime} \mathrm{N}$., long $145^{\circ} 50^{\prime} \mathrm{W}$. At this locality the Shale Wall Member is $120 \mathrm{~m}(400 \mathrm{ft})$ thick and is separated by a fault from the overlying Ayiyak Member. Displacement along the fault is minor. No other sections of the formation were measured in northeastern Alaska, so direct comparisons with other areas cannot be made. However, on the basis of the general stratigraphic details of other outcrop sections and the interval penetrated by drilling along the north coast (Fackler and others, 1971), this $260 \mathrm{~m}$ ( $850 \mathrm{ft}$ ) is probably a minimum thickness for the formation in northeastern Alaska.

The contact between the members of the Seabee Formation is a sharp sandstone-on-slale break. The contact with the underlying beds is a major Cretaceous unconformity throughout northern Alaska. In the area of this report the Seabee rests on beds ranging in age from Early Cretaceous to Middle Jurassic. At many localities on the Arctic Coastal Plain the formation is unconformably overlain by stratified to unsorted surficial deposits. Elsewhere, the sandstone of the Ayiyak Member grades into sandstone of the overlying Prince Creek and Schrader Bluff Formations.

Lithology._-The Shale Wall Member of the Seabee is mainly a dark, poorly consolidated, thinly bedded, bentonitic clay shale. The bentonite occurs primarily as

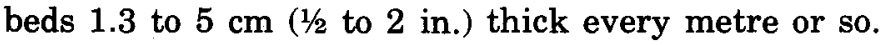
About $57 \mathrm{~m}(175 \mathrm{ft})$ of the upper part of the Ignek Creek section is composed of the fissile, organic paper shale. In this shale the bentonite beds are no more than $0.6 \mathrm{~cm} \mathrm{(1/4}$ 
and lithic fragments; this is also true of the Tertiary strata. Consequently, the Chandler Formation in northeastern Alaska cannot be younger than late $\mathrm{Al}-$ bian.

\section{COLVILLE GROUP}

The Colville Group was originally defined as a "series" by Schrader (1902) for a sequence of rocks exposed along the lower Colville River, about $160 \mathrm{~km}(100 \mathrm{mi})$ west of the report area. These beds were later redefined as the Colville Group by Gryc, Patton, and Payne (1951) and Gryc and others (1956). The group includes the Seabee, Prince Creek, and Schrader Bluff Formations, which were further divided into marine members and nonmarine tongues. The group was mapped only in the central and western parts of northern Alaska. Beds farther east, believed to be in part equivalent, were mapped as the upper part of the Ignek Formation by Keller, Morris, and Detterman (1961). During the recent investigations we have studied many more sections of these rocks, and here extend the term Colville Group into northeastern Alaska. The Ignek Formation is abandoned. The stratigraphic units of the Colville Group can be easily recognized and mapped in the northeast, so the extension of the term into this area is justified, particularly because the Ignek Formation included a heterogeneous assemblage of rocks of several ages.

\section{SEABEE FORMATION}

Name and distribution.-The Seabee Formation was originally defined as a member of the Schrader Bluff Formation by Gryc, Patton, and Payne (1951, p. 166). The member was redefined as a formation by Whittington (1956, p. 246) and further divided into the Shale Wall Member (Detterman and others, 1963, p. 269) and Ayiyak Member (Detterman, 1956b, p. 253). The formation was defined to include all marine strata in the Colville Group below the nonmarine Prince Creek Formation. These rocks include a lower bentonitic clay shale; in part a fissile organic shale (Shale Wall Member), and an upper sandstone and siltstone unit (Ayiyak Member).

The best exposures of the Seabee Formation in northeastern Alaska are in Ignek Valley (fig. 2, loc. 17) and along the north side of the Sadlerochit Mountains. In these areas the formation contains the distinctive "red beds" after which Ignek Valley is named. These highly colored "red beds" are very prominent and can be seen for many miles, particularly the ones near Red Hill. Leffingwell $(1919$, p. 121) considered the beds to be burnt coal. It is now believed that these beds were formed by the oxidation or possibly burning of the highly organic paper shale at the base of the Seabee Formation. This shale, when heated, turns red. The ac- tual source of the heat is not known; it could have been produced by a chemical reaction or by burning of the shale. Similar beds in the Smoking Hills, east of the Alaska-Yukon boundary, in northern Canada give off great clouds of smoke, although no fire is visible.

Other outcrops of the Seabee Formation are found as discontinuous cutbanks along many of the streams in the foothills and in the coastal plains (Reiser and others, 1971 and 1974). Geologic structures on the coastal plains are mainly flanked by low-dipping beds; consequently, the area of outcrop is generally broad. Beds of the Shale Wall Member are poorly consolidated and do not form good exposures except where capped by the overlying sandstone of the Ayiyak Member.

Thickness and stratigraphic relations.-Most exposures of the formation are incomplete and generally covered by rubble and mudflows formed of the weakly consolidated rocks. Consequently, many of the stratigraphic details, as well as possible changes in facies and thickness, are not well understood. One fairly good section of both members was obtained from the south side of Ignek Valley, along Ignek Creek (figs. 2 and 11), where approximately $260 \mathrm{~m}(850 \mathrm{ft})$ of beds are preserved (lat $69^{\circ} 33^{\prime} 30^{\prime \prime} \mathrm{N}$., long $145^{\circ} 50^{\prime} \mathrm{W}$. At this locality the Shale Wall Member is $120 \mathrm{~m}(400 \mathrm{ft})$ thick and is separated by a fault from the overlying Ayiyak Member. Displacement along the fault is minor. No other sections of the formation were measured in northeastern Alaska, so direct comparisons with other areas cannot be made. However, on the basis of the general stratigraphic details of other outcrop sections and the interval penetrated by drilling along the north coast (Fackler and others, 1971), this $260 \mathrm{~m}$ ( $850 \mathrm{ft}$ ) is probably a minimum thickness for the formation in northeastern Alaska.

The contact between the members of the Seabee Formation is a sharp sandstone-on-slale break. The contact with the underlying beds is a major Cretaceous unconformity throughout northern Alaska. In the area of this report the Seabee rests on beds ranging in age from Early Cretaceous to Middle Jurassic. At many localities on the Arctic Coastal Plain the formation is unconformably overlain by stratified to unsorted surficial deposits. Elsewhere, the sandstone of the Ayiyak Member grades into sandstone of the overlying Prince Creek and Schrader Bluff Formations.

Lithology._-The Shale Wall Member of the Seabee is mainly a dark, poorly consolidated, thinly bedded, bentonitic clay shale. The bentonite occurs primarily as

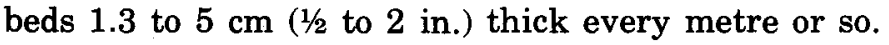
About $57 \mathrm{~m}(175 \mathrm{ft})$ of the upper part of the Ignek Creek section is composed of the fissile, organic paper shale. In this shale the bentonite beds are no more than $0.6 \mathrm{~cm} \mathrm{(1/4}$ 


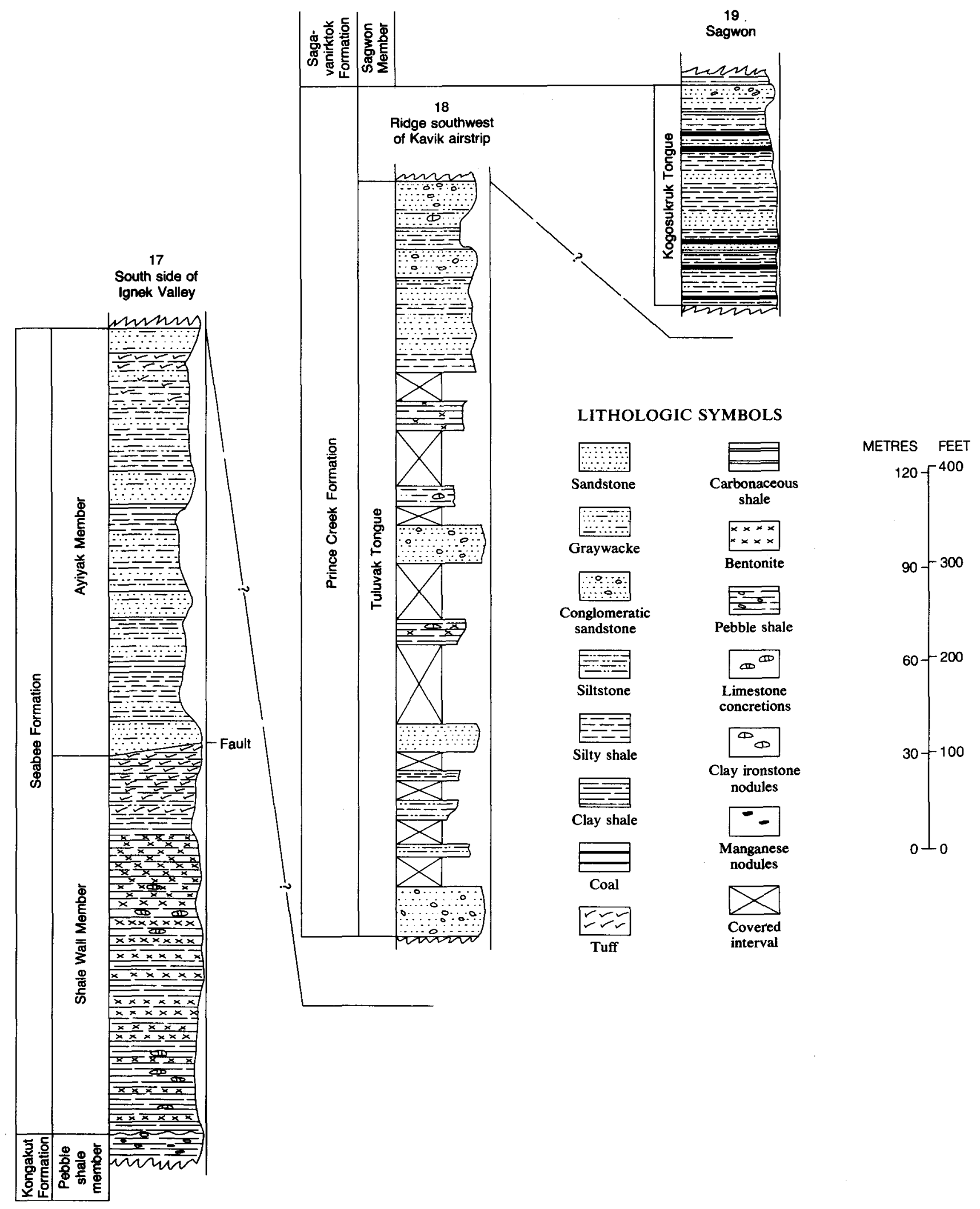

FigurE 11.-Measured sections of the Seabee and Prince Creek Formations. 
The stratigraphic relations between the tongues of the Prince Creek and the members of Schrader Bluff Formation are almost impossible to determine in northeastern Alaska, as the discontinuous outcrops rarely contain a contact between any of the subunits. The contacts are assumed to be gradational as they are in the type area. The Kogosukruk is overlain conformably by early Tertiary beds near Sagwon, and the Tuluvak is in apparent conformity with the Seabee Formation along Juniper Creek. Throughout most of northeastern Alaska the Prince Creek Formation is unconformably overlain by stratified to unsorted surficial deposits.

Lithology._As defined, the Prince Creek contains all of the Late Cretaceous nonmarine strata above the Seabee Formation (Gryc and others, 1951, p. 166). These are mainly sandstone, conglomerate, siltstone, shale, coal, and carbonaceous shale. The rocks are in general poorly consolidated and do not form good exposures; th is is particularly true of the Kogosukruk Tongue. The Kogosukruk Tongue is finer grained and darker than the Tuluvak Tongue, and it contains most of the thick coal beds.

The sandstone is primarily a subfeldspathic lithic arenite, 30 to 60 percent clasts of chert, quartzite, shale, and phyllite. Quartz makes up another 30 to 40 percent, feldspar about 5 to 8 percent, and sericitic clay matrix 5 to 8 percent. Some of the sandstone contains a tuffaceous or bentonitic matrix, and tuff is also present as clasts in some of the conglomeratic beds. Units of clean, porous sandstone 3 to $15 \mathrm{~m}$ (10 to $50 \mathrm{ft}$ ) thick are fairly common in the Tuluvak Tongue, but sandstone of the Kogosukruk is mainly thin bedded and dirty. Most of the Tuluvak sandstones contain a few pebbles 0.6 to 5 $\mathrm{cm}(1 / 4$ to $2 \mathrm{in}$.) in diameter, of the same composition as the lithic fragments in the sandstone.

The sandstone at the top of the Kogosukruk section at Sagwon (fig. 11, loc. 19) is of special interest. This rock is highly saturated by petroleum and gives off a strong odor of crude oil when fractured. The rock is stained a dark brown, and the odor is very strong even at a distance of 9 to $12 \mathrm{~m} \mathrm{(30} \mathrm{to} 40 \mathrm{ft}$ ). This same bed has been traced in numerous outcrops from Sagwon to the Arctic Coast near the mouth of the Aichilik River, a distance of $260 \mathrm{~km}(160 \mathrm{mi})$. This bed locally contains lenses of conglomerate, and pebbles of tasmanite are included with the other lithic clasts. The tasmanite was probably derived by the erosion of a Jurassic source bed to the south of this area (Boneham and Tailleur, 1972).

The oil-saturated sandstone is considered the uppermost unit of the Upper Cretaceous, primarily because it is more indurated and darker than the overlying rocks. In addition, in sections east of Sagwon the overlying rocks are not the same, indicating a disconformable relationship. This hiatus could, admittedly, be within either the Late Cretaceous or early Tertiary, but stratigraphic evidence suggests that it is between the two.

Siltstone and shale are a major part of both tongues of the Prince Creek Formation. Most of these are dark and contain considerable plant debris. The plant material is concentrated in some beds forming carbonaceous shale and coal units as much as $1.2 \mathrm{~m}$ (4 ft) thick in parts of the Kogosukruk. Coal was not found in the Tuluvak Tongue in northeastern Alaska, although it is present in the type area. The Tuluvak does, however, contain considerable carbonaceous material in the form of plant stems, twigs, and leaves.

Age.-The nonmarine Prince Creek Formation has yielded no identifiable fossils in northeastern Alaska. Plant fragments are common, but most are nondescript stems of little value. The age of these rocks is based entirely on analogy with similar beds in the type area where they intertongue with fossil-bearing marine strata of the Schrader Bluff Formation. These fossils are considered to represent the Santonian and lower Campanian Stages of the Late Cretaceous (Jones and Gryc, 1960, p. 153). In the type area for these formations the lowest part of the Tuluvak underlies and the Kogosukruk overlies all parts of the Schrader Bluff Formation. Thus, the Prince Creek probably represents a greater part of the Late Cretaceous than does the marine sequence. An earlier age limit is placed on these strata by the fact that they overlie the late Turonian beds of the Seabee Formation. The Kogosukruk may be in part of Maestrichtian age but can be no younger than Cretaceous, as the overlying basal Sagavanirktok Formation contains a Paleocene flora.

\section{SCHRADER BLUFF FORMATION}

Name and distribution--The Schrader Bluff Formation was defined by Gryc, Patton, and Payne (1951, p. 165 ) as the uppermost marine unit of the Cretaceous in central Alaska, and the type locality was designated on the lower Anaktuvuk River at Schrader Bluff, after which it was named. They further divided the formation into three members: in ascending order, the Seabee, Tuluga, and Sentinel Hill. Whittington (1956, p. 249252) redefined the Schrader Bluff. He raised the Seabee to formation status, abandoned the Tuluga Member, and established two new members, Rogers Creek and Barrow Trail. The Sentinel Hill Member remained unchanged (fig. 4).

In northeastern Alaska the formation is present in discontinuous cutbanks along some of the major streams on the Arctic Coastal Plain. It is currently mapped as undivided from the Prince Creek Formation (Reiser and others, 1971 and 1974). The members, as well as the formation, can be separated in individual outcrops but are combined for mapping convenience. 
The most complete section is along the Canning River, starting opposite the west end of the Sadlerochit Mountains and continuing north for about $13 \mathrm{~km}(8 \mathrm{mi})$. Most of the outcrops are between the Sagavanirktok and Jago Rivers.

Thickness and stratigraphic relations.-Partial sections of the three members of the Schrader Bluff Formation investigated along the lower Canning River, lat $69^{\circ} 36^{\prime}$ to $69^{\circ} 42^{\prime} \mathrm{N}$., long $146^{\circ} 14^{\prime}$ to $146^{\circ} 17^{\prime}$ W. (fig. 2, loc. 20 , and fig. 12), indicate that the formation is at least $330 \mathrm{~m}(1,100 \mathrm{ft})$ thick. These sections were not investigated in detail, so the thickness there may be considerably greater-more like that at the type locality at Schrader Bluff (Detterman and others, 1963).

Stratigraphic relations between the Schrader Bluff

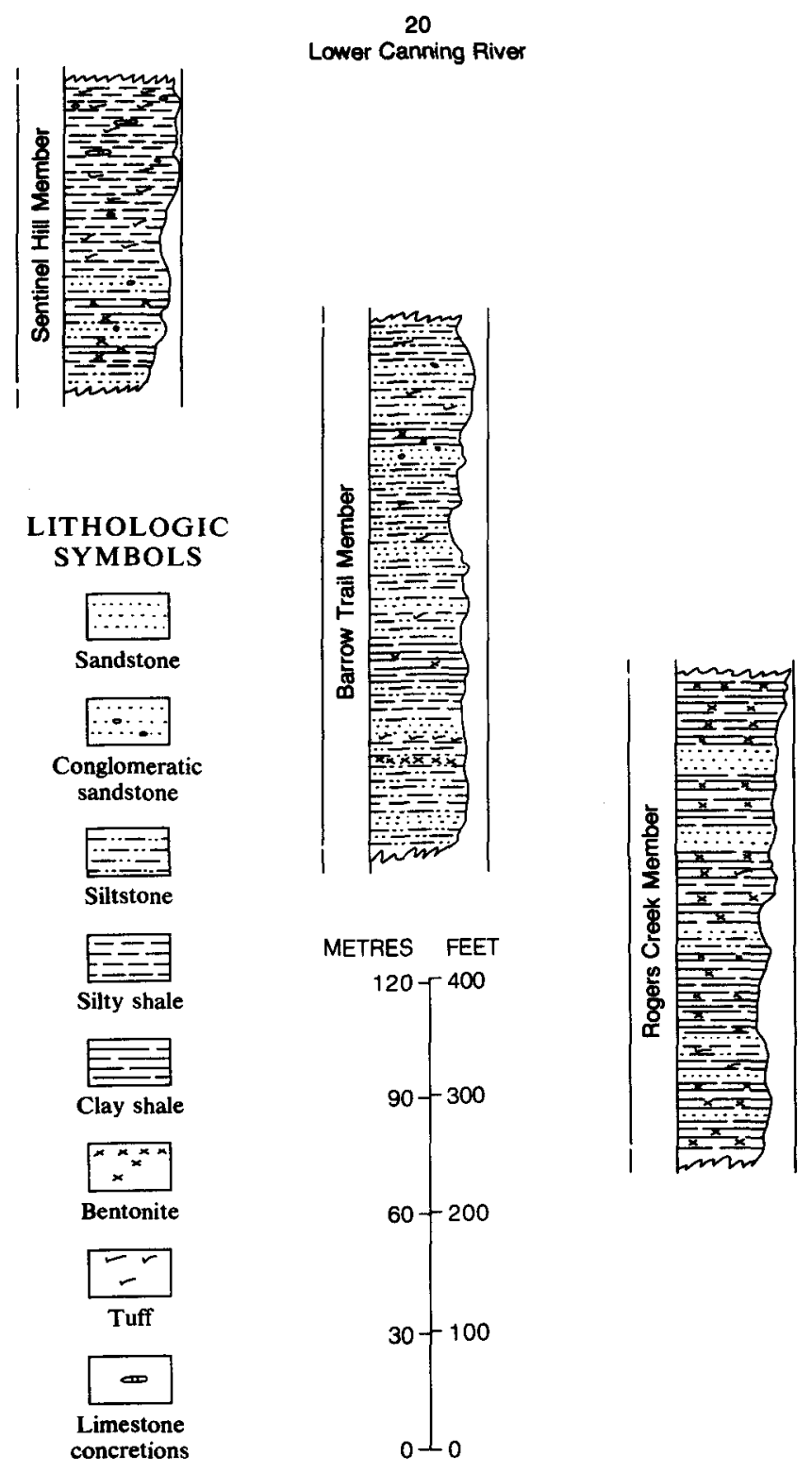

Figure 12.-Generalized sections for the Schrader Bluff Formation. and Prince Creek Formations are uncertain in northeastern Alaska. They probably can be determined with additional work but, at present, the contacts are considered as gradational between the intertonguing marine and nonmarine units, as in the type area.

Lithology. - The Rogers Creek Member, the lowest stratigraphic unit of the formation, consists primarily of rusty-weathering bentonitic clay shale with thin interbeds of very fine grained sandstone and siltstone. Load and flute casts, suggesting turbidity current deposition, are fairly abundant on the base of most sandstone beds. The siltstone is micaceous and tuffaceous.

The Barrow Trail Member is mainly sandstone of the feldspathic wacke type, thin to massively bedded, fine to coarse grained, and commonly tuffaceous. A few beds contain small pebbles of chert and quartz. Interbeds of siltstone and shale are common but not as abundant as in the underlying Rogers Creek Member. Tuff and bentonite are also common, both as interbeds and as the matrix of some sandstone and siltstone units. The tuff gives these rocks an overall light-gray color. One tuff examined in thin section was seen to be welded, with good parallel orientation of the shards. A few unburst bubbles were still visible, and the shards were only slightly devitrified. In general, however, the tuff content of the rocks in northeastern Alaska is considerably less than in the type area near Umiat.

The Sentinel Hill Member is mainly thin-bedded, light-gray to tan, tuffaceous siltstone and silty shale. Locally the siltstone contains a few small chert granules and large laminated limy concretions. A few dark finegrained calcareous sandstone interbeds occur near the base of the section. The sandstone contains abundant carbonaceous material and a few chert pebbles and mud lumps.

Age.-Few megafossils have been found in the Schrader Bluff Formation in northeastern Alaska. The recent investigations obtained only numerous small fish fragments in a tuffaceous siltstone bed along the west side of the Jago River; these have not been identified. Keller, Morris, and Detterman (1961, p. 206) reported finding the pen of a large squid, Teusoteuthis longus Logan, in correlative beds along Juniper Creek. This squid is common in the Niobrara Formation of Kansas, which is from the Coniacian and Santonian Stages of the Late Cretaceous. This age is in keeping with that obtained from pelecypods in the Schrader Bluff type area, where fossiliferous beds have produced Inoceramus steenstrupi de Loriol and I. patootensis de Loriol characteristic of the Santonian and Campanian Stages (Jones and Gryc, 1960, p. 153).

Most of the shale samples collected for microfossils from the Schrader Bluff Formation were barren. One sample obtained from the Sentinel Hill Member along 
the east side of the Canning River contained a few specimens of the arenaceous foraminifer Haplophragmoides rota Nauss. According to Bergquist (written commun., 1972), this species is common in the Schrader Bluff Formation and also in the Grizzly Bear Shale of the Belly River Group (Campanian Stage) of Alberta, Canada.

\section{SAGAVANIRKTOK FORMATION}

Name and distribution.-The Sagavanirktok Formation was named by Gryc, Patton, and Payne (1951, p. 167 ) for a sequence of poorly consolidated siltstone, sandstone, conglomerate, and lignite exposed in Franklin Bluffs along the lower Sagavanirktok River. These rocks are considered to be Paleocene and Eocene on the basis of fossil flora reportedly collected from them (MacNeil and others, 1961, p. 1807; Keller and others, 1961, p. 208). Another sequence of the Sagavanirktok Formation consisting of poorly consolidated sandstone and siltstone along Carter Creek was briefly investigated by Morris (1953). The Carter Creek section contains fossils of late Miocene to Pliocene age, according to MacNeil (1957), who considered these beds to be the same age as the Nuwok Formation of Dall (1920).

The discovery of oil at Prudhoe Bay and the subsequent increased geologic investigation of the Arctic Coastal Plain by geologists of many petroleum companies and the U.S. Geological Survey resulted in an accumulation of data which in turn provoked considerable confusion as to what strata should be included in the Sagavanirktok Formation. Many of the wells drilled near Prudhoe Bay penetrated thick coal beds that are believed to be Tertiary, but the type locality at Franklin Bluffs contains no coal and there is only a minor amount at Carter Creek. In addition, the fossil flora which indicated a Paleocene and Eocene age for the type locality was in fact collected near Sagwon and not at Franklin Bluffs; the beds at Franklin Bluffs are younger than Eocene.

The recent geologic investigations of northeastern Alaska covered many of the exposures of poorly consolidated rock on the Arctic Coastal Plain. In an attempt to dispel the confusion surrounding the stratigraphic limits of the formation, we here include all the beds above the top of the Upper Cretaceous Prince Creek Formation and below the Quaternary (Gubik Formation) surficial deposits in the Sagavanirktok Formation. The Sagavanirktok is further divided into three newly named members: in ascending order, the Sagwon, Franklin Bluffs, and Nuwok Members. Type sections are designated for each member, as no single outcrop contains a complete sequence.

The Sagwon Member is best exposed in bluffs along the west side of the Sagavanirktok River about $3 \mathrm{~km}(2$ $\mathrm{mi}$ ) northwest of Sagwon (fig. 2, loc. 23). The type section starts at VABM Gard and continues south for about 1.6 $\mathrm{km}(1 \mathrm{mi})$ along the river bluff, lat $69^{\circ} 23^{\prime} 30^{\prime \prime}$ to $69^{\circ} 24^{\prime} 30^{\prime \prime}$ N., long $148^{\circ} 39^{\prime} 30^{\prime \prime}$ to $148^{\circ} 41^{\prime} \mathrm{W}$. Other sections of the member are present in discontinuous outcrop along the streams on the coastal plain as far east as the Canning River. The Sagwon has not been identified east of the Canning River, but may be present under the surficial deposits. The westernmost occurrence of these rocks is in the White Hills, about $32 \mathrm{~km}$ (20 mi) northwest of Sagwon. Fairly good exposures are present along Fin Creek near its junction with Juniper Creek.

The Franklin Bluffs Member is well exposed in a number of small stream gullies that cut the west side of Franklin Bluffs, a prominent landmark on the Arctic Coastal Plain about $48 \mathrm{~km}$ (30 mi) from the coast (fig. 2, loc. 22). The type section is designated as along the stream $1.8 \mathrm{~km}(1.1 \mathrm{mi}) \mathrm{S}$. $10^{\circ} \mathrm{W}$. of VABM Greta, lat $69^{\circ} 49^{\prime} \mathrm{N}$., long $148^{\circ} 39^{\prime}$ to $148^{\circ} 41^{\prime} \mathrm{W}$. The member is partly exposed along most of the streams on the coastal plains between the White Hills and the Niguanak River; it is more widely distributed than any other part of the Sagavanirktok Formation, and generally forms the northernmost low hills on the Arctic Coastal Plain.

The name Nuwok Member is here proposed for the sequence of rocks well exposed in a series of low bluffs along the east side of Carter Creek about $2.4 \mathrm{~km}(11 / 2 \mathrm{mi})$ south of Camden Bay (fig. 2, loc. 21). These strata were originally named the Nuwok Formation by Dall (1919). Although the name was used later by Dall (1920), Leffingwell (1919), and MacNeil (1957), it has never been formally accepted by the U.S. Geological Survey. The relationship of the beds on Carter Creek to the Sagavanirktok Formation was unknown when MacNeil (1957, p. 120) named a pelecypod after the Nuwok, Chlamys nuwokensis, and since the Carter Creek beds were apparently much younger than the Franklin Bluffs section, MacNeil assumed that the rocks belonged to different formations. Additional work has shown that the fossiliferous beds on Carter Creek directly overlie strata equivalent to the Franklin Bluffs Member and that all are part of one nearly continuous Tertiary sequence. We therefore assign the Nuwok Member to the Sagavanirktok Formation and restrict it to the upper $80 \mathrm{~m}$ (266 ft) of strata exposed in the bluffs at the type section, lat $69^{\circ} 57^{\prime} \mathrm{N}$., long $144^{\circ} 39^{\prime} 30^{\prime \prime} \mathrm{W}$. This locality is the only known occurrence of the member. Beds of the Gubik Formation (Pleistocene) overlie the Nuwok Member at Carter Creek.

Thickness and stratigraphic relations.-Although a complete section of the Sagavanirktok Formation has not been found at any one locality, a sequence representative of the formation can be compiled (fig. 13). By correlating partly exposed sections, a minimum thickness of about $1,152 \mathrm{~km}(3,780 \mathrm{ft})$ is indicated, but there 


\section{LITHOLOGIC SYMBOLS}

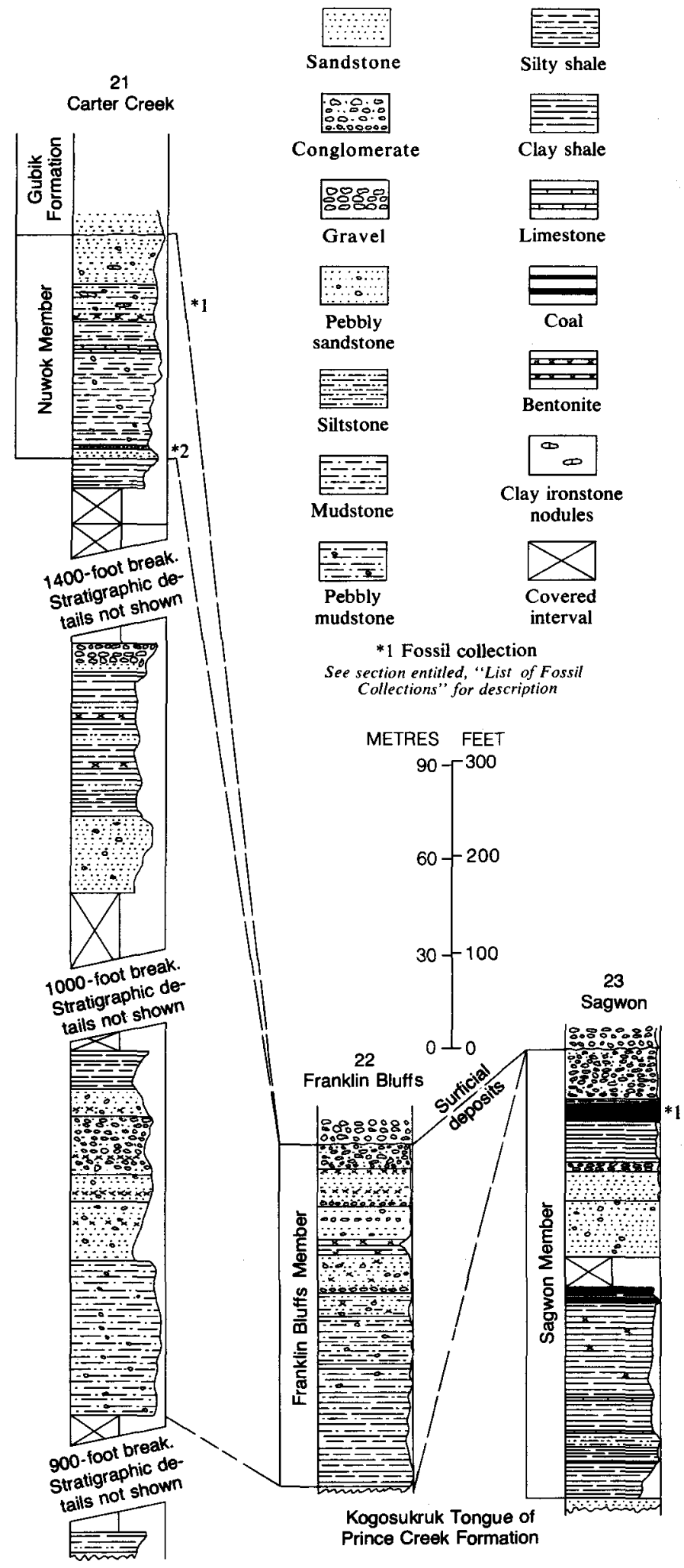

Figure 13.'-Type sections for members of the Sagavanirktok Formation. may be as much as 1,500 or $1,800 \mathrm{~m}(5,000$ or $6,000 \mathrm{ft})$. Wells drilled along the north coast penetrate between 600 and 1,500 $\mathrm{m}(2,000$ and 5,000 ft) of Sagavanirktok rocks.

The Sagwon Member is $143 \mathrm{~m}$ (470 ft) thick at the type section, where it is unconformably overlain by terrace gravel, and a similar section is present in the White Hills. A somewhat thicker section may be present near the junction of Fin and Juniper Creeks, where Keller, Morris, and Detterman (1961) reported $625 \mathrm{~m}(2.045 \mathrm{ft})$ of Sagavanirktok rocks. The lower $365 \mathrm{~m}(1,200 \mathrm{ft})$ of that section is probably equivalent to the Sagwon, although some of the basal beds may be Upper Cretaceous. The contact between the Sagwon and the underlying Kogosukruk Tongue is conformable and apparently gradational; it can be identified with confidence only where exposures are good, as both stratigraphic units contain coal and poorly consolidated rock. The sandstone of the Kogosukruk is somewhat more indurated and darker than the Sagwon, and the coal is slightly higher grade.

The Franklin Bluffs Member is at least $900 \mathrm{~m}(3,000$ $\mathrm{ft})$ thick and may be as much as $1,500 \mathrm{~m}(5,000 \mathrm{ft})$ thick. Only about $105 \mathrm{~m}$ (350 ft) is actually exposed beneath the high-level terrace gravel at the type section. Consequently, the partly exposed section along Carter Creek is listed as a reference locality (fig. 13, column 21 ). The contact with the underlying Sagwon Member is probably conformable, although not visible in these poorly exposed sections. The upper contact is, at least in part, an unconformity where the number is overlain by unconsolidated terrace gravel. Elsewhere, as on Carter Creek, these rocks appear to be conformable and gradational into the overlying Nuwok Member.

The Nuwok Member is the youngest Tertiary unit exposed in northeastern Alaska. The type section is about $80 \mathrm{~m}(270 \mathrm{ft})$ thick and is the only known occurrence of these rocks. The lower contact is placed at the base of a poorly consolidated sandstone and is conformable and gradational.

Lithology.-The Sagwon Member is the coalbearing sequence of the Tertiary in northeastern Alaska. The coaly beds are mainly lignite and carbonaceous shale, and individual beds are as much as $6 \mathrm{~m} \mathrm{(20 \textrm {ft } )}$ thick with abundant shale partings. The coal is interbedded with dark-gray to brown fissile clay shale and siltstone that are slightly bentonitic and contain a few clay ironstone nodules. Massive units of poorly consolidated sandstone and conglomerate form the upper part of the Sagwon section. The sandstone is a lithic arenite composed of 60 to 70 percent clasts of chert and quartzite, which are also the main constituents of the conglomerate. Quartz, minor feldspar, and carbonaceous material make up most of the remainder. All thin 
sections of sandstone contain not more than 5 percent matrix, usually sericitic clay or montmorillonite. Crossbedding of the shallow-water to deltaic type is common in both sandstone and conglomerate, and indicated a source to the southwest.

The Franklin Bluffs Member is a cyclic-bedded subaerial deposit. The cycle of deposition is repeated four or five times in northeastern Alaska, but only one cycle is exposed at Franklin Bluffs. At that locality (fig. 13) the cycle starts with a thick unit of thinly laminated gray to brown clay and silt beds suggestive of a playa lake deposit. These beds commonly contain randomly distributed small chert pebbles and mud lumps along the bedding planes. Most pebbles are on the upper surface of the clay units and are of a size and shape that could be moved by wind. Desiccation cracks are preserved in a few beds at the south end of the bluff section. Thin sections of these rocks show them to be about 75 percent clay with well-developed platy arrangement of the mica. The silt laminae are composed mainly of quartz and feldspar grains. Organic material is commonly present along bedding planes, and there is considerable limonite staining. Overlying the laminated silt and clay are massive units of pink, tan, orange, and yellow unconsolidated sand and gravel. Limonitic zones several inches thick locally cement the sand and gravel into wellindurated rock. Large-scale irregular crossbedding, probably of eolian origin, is common in some sand units. Beds of volcanic ash are interlayered with the sand and gravel.

The depositional environment of the Franklin Bluffs Member is imperfectly known largely owing to poor exposures. The combination of lithologic types is suggestive, however, of semiarid conditions in which varved silt and clay beds were deposited in large shallow lakes. The varved sediments were then overlain by red-bed-type sands and gravel deposited by water and wind. The organic content of the sediments is markedly less than that of the underlying Sagwon Member; this might further confirm a semiarid environment.

The Nuwok Member represents a return to nearshore marine deposition. The section on Carter Creek is within $2.4 \mathrm{~km}(1.5 \mathrm{mi})$ of the present coast and at $46 \mathrm{~m}$ (150 ft) altitude, so marine deposition is not surprising considering the young age of these beds. The sequence starts with a crossbedded sand unit capped by a pebble conglomerate. The sand contains a few thin-shelled pelecypods and probably represents a beach deposit. The conglomerate is overlain by pebbly mudstone and siltstone with a few thin silty limestone interbeds that are interpreted as lagoonal deposits. The section is capped by about $15 \mathrm{~m}$ ( $50 \mathrm{ft}$ ) of unconsolidated sand with a few chert and quartz pebbles. This unit is crossbedded and locally cemented by limonite; it probably was deposited as a barrier beach deposit similar to those formed along the Arctic Coast today.

Age.-The Sagavanirktok Formation contains fossil flora and fauna that indicate a Tertiary age. The flora was collected from the coal-bearing Sagwon Member and includes such early Tertiary forms as Metasequoia occidentalis (Newberry) Chaney, Trapa microphylla Lesquereux, Cinnamonum ficoides Hollick, and Pterospermites conjunctious Hollick. These are correlated with Paleocene and Eocene beds elsewhere in Alaska (MacNeil and others, 1961; Keller and others, 1961).

The Franklin Bluffs Member has produced no fossils, and probably will not produce many if the paleogeography has been correctly interpreted. Stratigraphic breaks cannot be picked within the surface exposures, largely because outcrops are poor, but deposition is assumed to have been nearly continuous. Since the member represents most of the exposed Tertiary beds, we suggest that the Franklin Bluffs Member represents at least the Oligocene(?) and Miocene(?) strata, and may possibly include more of the Tertiary sequence.

The Nuwok Member contains a molluscan fauna that has been known for many years (Dall, 1919, 1920; Leffingwell, 1919; Morris, 1953; MacNeil, 1957). The main elements of this fauna are Arctica carteriana MacNeil and Chlamys nuwokensis MacNeil. These fossils are considered by MacNeil to be late Miocene or early Pliocene (1957, p. 101), although they bear little resemblance to Miocene and Pliocene faunas in southern Alaska. The Nuwok contains a very prolific microfauna including foraminifers and ostracodes that were assigned a similar age by Todd (1957). Recent collections of microfossils were studied by Bergquist, who considers the fauna to be more closely related to latest Pliocene or early Pleistocene forms (written commun., 1972). The age as determined by Bergquist seems to be more in keeping with the stratigraphic assignment of these beds which is late Miocene(?) and Pliocene. Microfossils from the type section are listed in table 3 . Bergquist considers the following species to be endemic to the Nuwok Member: Elphidiella(?) brunescens Todd, Elphidium discoidale (d'Orbigny), Trifarina fluens (Todd), Nonion cf. N. labridoricum (Dawson), Melonis erucopsis (Todd), Globulina auriculata subsp. arctica Hoglund, and Cibicides perlucidus Nuttall.

The uppermost beds of the Carter Creek section may be of Pleistocene age as suggested by the microfauna, since the late Tertiary megafauna was not found in the

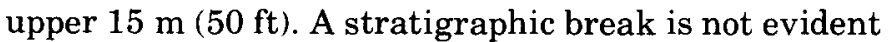
within or below these unconsolidated sands; consequently, they are included as part of the Carter Creek section.

\section{GUBIK FORMATION}

Name and distribution.-The Gubik Formation 
was originally termed the Goobic Sands by Schrader (1902, p. 249-250) and Gubik Sand by Schrader (1904,p. 93). He applied the name to Pleistocene unconsolidated deposits along the Colville River on the Arctic Coastal Plain in central Alaska. This stratigraphic unit was later redefined by Gryc, Patton, and Payne (1951, p. 167 ) as the Gubik Formation. The formation was studied in considerable detail in northwestern Alaska by Black (1964), who divided it into three units: in ascending order, the Skull Cliff, Meade River, and Barrow. We recognize the Gubik Formation in northeastern Alaska.

The recent geologic investigations were primarily concerned with the indurated bedrock and secondarily with the unconsolidated surficial materials on the Arctic Coastal Plain. A few sections of the Gubik were investigated along the Niguanak River and in the area between Carter and Marsh Creeks. In addition, the for- mation was noted at a number of other localities. Although its exact area is unknown, it is probably present on the coastal plain throughout northeastern Alaska. The section on the Niguanak River (fig. 2, loc. 24) is about $120 \mathrm{~m}(400 \mathrm{ft})$ above sea level and $32 \mathrm{~km}(20 \mathrm{mi})$ from the coast. This is probably about the southernmost occurrence of the formation, but the Gubik can be expected to underlie most areas to the north.

Thickness and stratigraphic relations.-The Gubik Formation is at least $10 \mathrm{~m}$ ( $35 \mathrm{ft}$ ) thick along the Niguanak River, lat $69^{\circ} 49^{\prime} 30^{\prime \prime}$ N., long $143^{\circ} 05^{\prime} 30^{\prime \prime}$ W., where an incomplete section was measured (fig. 14). The base of the sequence is not exposed, so the actual thickness is unknown, but it probably is less than the $60+\mathrm{m}$ $(200+\mathrm{ft})$ exposed near Point Barrow (Black, 1964).

The deposit is unconformably overlain by poorly stratified sand and gravel interpreted as glacial outwash. The lower contact, also an unconformity, is not

TABle 3.-Foraminifera distribution chart for the Nuwok Member of the Sagavanirktok Formation $[\mathrm{R}=$ rare $(1-10) ; \mathrm{C}=$ common $(11-25) ; \mathrm{A}=$ abundant $(>25)]$

\begin{tabular}{|c|c|c|c|c|c|c|c|}
\hline Sample number & $\begin{array}{l}\text { 69ADt-150 } \\
\text { No. } 1 \\
\end{array}$ & $\begin{array}{l}\text { 69ADt-150 } \\
\text { No. } 2\end{array}$ & 70ADt-150 & $70 \mathrm{ADt}-150$ & 70ADt-150 & $70 \mathrm{ADt}-150$ & $70 \mathrm{ADt}-150$ \\
\hline Position below & 44.2-Base & $13.1-44.2$ & $67.0-79.2$ & $59.4-67.0$ & $44.2-59.4$ & $21.3-44.2$ & $1.2-21.3$ \\
\hline top of member & 145-Base & $44-145$ & $220-260$ & $195-220$ & $145-195$ & $70-145$ & $4-70$ \\
\hline Elphidiella? brunescens Todd & $\mathbf{R}$ & A & A & A & A & A & A \\
\hline Elphidium discoidale? (d'Orbigny) _- & C & $\mathbf{R}$ & $-\cdots$ & $\mathrm{R}$ & $\mathbf{A}$ & $\mathbf{R}$ & --- \\
\hline cf. E. hughesi Cushman and Grant & $\mathbf{R}$ & --- & $-\cdots$ & --- & & ---- & ---- \\
\hline $\begin{array}{l}\text { ustruletum Todd } \\
\text { sp. }\end{array}$ & $-\overline{\mathbf{R}}$ & $\mathbf{R}$ & 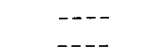 & $-\mathbf{R}^{--}$ & $\mathbf{R}$ & --- & -- \\
\hline Anomalina? sp. & --- & A & $\mathbf{R}$ & --2 & $\mathbf{R}$ & $\mathbf{R}$ & --- \\
\hline Cassidulina ef. C. subglobosa Brady & & & --- & --+ & ---- & $\mathrm{R}$ & --- \\
\hline Cassidella sp. & $\mathbf{R}$ & $\mathbf{R}$ & ---- & ---- & & $\mathbf{C}$ & --- \\
\hline Cibicides aff. C. gramus Todd & 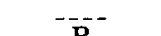 & R & $\mathbf{R}$ & --- & $\underset{\mathbf{R}}{\mathbf{R}}$ & $\mathrm{R}$ & $\stackrel{\mathrm{C}}{\mathrm{R}}$ \\
\hline & $\underset{\mathbf{R}}{\mathbf{R}}$ & $\mathrm{R}$ & $\mathbf{R}$ & ---- & $\mathbf{R}$ & ---- & $\mathrm{R}$ \\
\hline sp. & $\mathbf{R}$ & ---- & $-\cdots$ & $\mathbf{R}$ & $\mathrm{A}$ & $\overline{\mathrm{R}}$ & --- \\
\hline Cornuspira sp. & $\mathbf{R}$ & $\mathrm{R}$ & $-\cdots$ & --- & $\mathrm{R}$ & $-\ldots$ & \\
\hline Bulimina sp. & C & A & A & --- & A & A & A \\
\hline Dentalina sp. & $\mathbf{R}$ & $\mathrm{R}$ & --- & --- & $\mathbf{R}$ & $\mathbf{R}$ & $\mathrm{R}$ \\
\hline $\begin{array}{l}\text { Fissurina semimarginata (Reuss) } \\
\text { globulosa Bornemann }\end{array}$ & --- & $\mathbf{R}$ & --- & --- & $\mathbf{R}$ & --- & $\mathbf{R}$ \\
\hline sp. $-1,-$ & --- & & --- & -1 & $\mathbf{R}$ & --- & $\mathbf{R}$ \\
\hline Falsocibicides sp. & --- & $\mathrm{R}$ & & --- & $-\cdots$ & & \\
\hline Glandulina laevigata d'Orbigny & $\ldots$ & --- & $\mathrm{R}$ & $\mathbf{R}$ & & $\mathbf{R}$ & \\
\hline Globulina inaequalis Reuss & $-\cdots$ & --- & --- & --- & $\underset{\mathbf{R}}{\mathbf{R}}$ & $\mathbf{R}$ & R \\
\hline Globobulimina auriculata sub sp. arctica Hoglund & $\mathrm{C}$ & $\stackrel{\mathbf{C}}{\mathbf{C}}$ & $\mathbf{R}$ & --- & $\begin{array}{l}\mathbf{R} \\
\mathbf{C}\end{array}$ & $\mathbf{R}$ & $\stackrel{\mathrm{C}}{\mathrm{C}}$ \\
\hline Gyroidina sp. & $\mathbf{R}$ & --- & $\mathbf{R}$ & -- & $\mathbf{R}$ & --- & \\
\hline Lagena cf. L. striata (Montagu) & ---- & --- & $\underset{\mathbf{R}}{\mathbf{R}}$ & --- & --- & $\mathbf{R}$ & \\
\hline sp. -1 & --- & --- & $\mathbf{R}$ & --- & --- & --- & R \\
\hline Fissurina marginata (Montagu) & & --- & $\underset{\mathbf{R}}{\mathbf{R}}$ & --- & --- & $-\overrightarrow{\mathbf{R}}$ & \\
\hline $\begin{array}{l}\text { Melonis crucopis (Todd) } \\
\text { Nonion cf. } N \text {. labriodoricum (Dawson) }\end{array}$ & $\stackrel{R}{R}$ & $\stackrel{\mathrm{C}}{\mathrm{R}}$ & $\begin{array}{l}\mathbf{C} \\
\mathbf{R}\end{array}$ & --- & $\mathrm{C}$ & R & A \\
\hline $\begin{array}{l}\text { Nonion ef. } N \text {. labriodoricum (Dawson) } \\
\text { sp. }\end{array}$ & $\begin{array}{l}\mathbf{C} \\
\mathbf{R}\end{array}$ & $\mathbf{R}$ & $\mathbf{K}$ & ---- & $-\cdots$ & & \\
\hline Quinqueloculina sp. & $\mathbf{K}$ & $\cdots$ & --- & --- & $-\overline{\mathbf{R}}$ & $\begin{array}{l}\mathbf{R} \\
\mathbf{R}\end{array}$ & --- \\
\hline Scutuloris? sp. & $\mathbf{R}$ & $\mathbf{R}$ & $-\cdots$ & $-\cdots$ & $\mathbf{R}$ & $\overrightarrow{\mathbf{R}}$ & $\mathbf{R}$ \\
\hline Haplophragmoides sp. & & & ---- & ---- & $\mathbf{R}$ & $-\cdots$ & ---- \\
\hline Miliolinella circularis? (Bornemann) & $\mathbf{R}$ & $\mathbf{R}$ & --- & ---- & $\mathrm{R}$ & ---- & ---- \\
\hline Robertinoides? charlottensis (Cushman) & --- & --- & --- & --- & $\mathbf{R}$ & & \\
\hline Polymorphina sp. & --- & --- & -..- & $\mathbf{R}$ & --- & $\mathbf{R}$ & $\mathbf{R}$ \\
\hline Pullenia salisbury R. E. and K. C. Stewart & --- & --- & ---- & ---- & ---- & --- & $\mathrm{R}$ \\
\hline Oolina laevigata d'Orbigny & $-\cdots$ & $-\cdots$ & ---- & ---- & & ---- & $\mathrm{R}$ \\
\hline squamosa (Montagu) & $-\ldots$ & --- & $\mathbf{R}$ & --- & $\mathbf{R}$ & --- & $\mathbf{R}$ \\
\hline Trifarina fluens (Todd) & $\mathbf{R}$ & --- & A & --- & A & ---- & \\
\hline
\end{tabular}




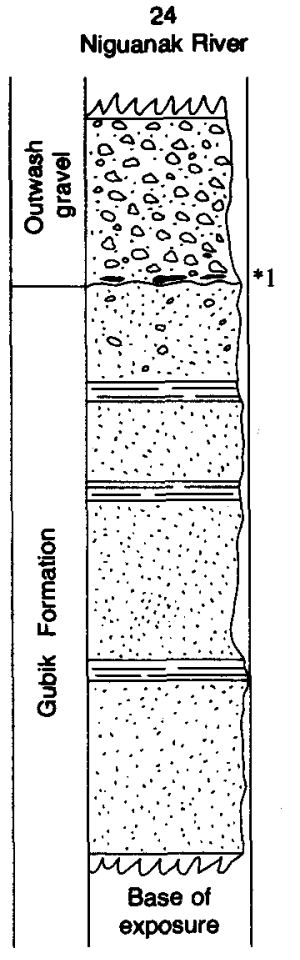

Figure 14.-Measured section of the Gubik Formation.

exposed where the section was measured but is exposed $16 \mathrm{~km}$ (10 $\mathrm{mi}$ ) further north along the Niguanak, where the Gubik overlies shale of Late Cretaceous age. The formation also overlies late Tertiary beds between Carter and Marsh Creeks.

Lithology.-The Gubik Formation exposed along the Niguanak River is primarily clean crossbedded sand, with a few small pebbles of black chert in the upper part (fig. 14). The sand units are 1.5 to $3 \mathrm{~m}$ (5 to 10 ft) thick and are separated by thin beds of dark-bluishgray laminated silt and clay. The deposit is considered to be marine, although fossils have not been found at this locality.

Coarse gravel is the main constituent of the Gubik Formation exposed between the Canning and Kavik Rivers (Reiser and others, 1971). The clasts are primarily roller shaped, 8 to $13 \mathrm{~cm}$ ( 3 to $5 \mathrm{in}$.) long, composed of gray quartzite, tuff, gray chert, and minor limestone that is highly weather. The gravel contains a considerable amount of sand and silt and has a characteristic rusty-orange color caused by limonite staining.

Remnants of a high-level gravel terrace cap many of the hills along the south edge of the Arctic Coastal Plain, and also at many places on the coastal plain. This is a clean gravel primarily of cobble-sized clasts composed of light-colored quartz, gray and green tuff, gray to black chert, and minor amounts of limestone. The abundance of light-colored constituents gives these gravels a characteristic white weathered surface considerably different from the rusty-orange-weathering gravel of the Gubik Formation. The gravel in the Gubik generally contains much sand and silt, which is absent from the white gravel. The relationship between these two deposits is not entirely known, although they are commonly closely associated throughout the coastal plan. The Gubik gravels are believed to be formed in part from a reworking of the white gravel.

The Gubik Formation exposed in northeastern Alaska is probably equivalent to the Barrow unit of the formation, as described by Black (1964, p. 77-88).

Age.-The Gubik Formation is of Pleistocene age, but the exact position within the Pleistocene is not known. Black (1964, p. 89) equated the Skull Cliff unit with the Illinoian Glaciation, the Meade River unit with the Sangamon Interglaciation, and the Barrow unit with the Wisconsin Glaciation. A carbon-14 age of over 34,000 years was obtained from wood collected from the unconformity between the Gubik and the overlying outwash gravel at the locality on the Niguanak River. Porter (1966, p. 98) obtained a carbon-14 age of 13,270士 160 years for a sample from the lower part of the Itkillik Glaciation, which he equates with the Wisconsin Glaciation. If the Gubik, as exposed in northeastern Alaska, is equivalent to the Barrow unit, as suggested, then all parts of the formation are older than the Wisconsin Glaciation. The outwash gravel overlying the Gubik on the Niguanak is considered to be derived from the Itkillik Glaciation.

The lower limit of the Gubik, also, cannot be placed precisely. In the area between Carter and Marsh Creeks the formation unconformably overlies fossiliferous late Pliocene beds, so the Gubik is probably entirely Quaternary. A few microfossils were obtained from a shale sample in this area. They include Glomospira sp., Eggerella sp., Valvulinera sp., Biloculinella sp., and Cribroelphidium sp., which have been found previously in the Gubik Formation, as well as Holocene deposits of the Arctic Ocean (Bergquist, written commun., 1972), but these are of little value for precise age determinations.

\section{LIST OF FOSSIL COLLECTIONS}

This is a partial listing of major megafossil collections obtained in northeastern Alaska between 1969 and 1972, giving location and content for each sample. Collections are listed by stratigraphic unit, and those with numeral prefixes are keyed to sections shown in figures 5 to 14 . Some of the geographic features listed here are not shown in figure 2 but can be found on the appropriate 1:250,000 quadrangle map. 


\section{SADLEROCHIT GROUP}

\section{ECHOOKA FORMATION}

\section{JOE CREEK MEMBER (LOWER AND UPPER} PERMIAN)

1. 23464-PC (U.S. Geological Survey, Permian and Carboniferous locality number); Table Mountain quadrangle; type section, mountain north of Joe Creek; lat $68^{\circ} 59^{\prime} 30^{\prime \prime}$ N., long $141^{\circ} 26^{\prime} \mathrm{W}$; $7.7 \mathrm{~km}(4.8 \mathrm{mi})$ west of VABM Raeburn: Kochiproductus sp. (Guadalupian).

2. 23463-PC; same locality: Derbyia sp., Yakovlevia sp., Horridonia sp., Spiriferella sp., Kochiproductus sp., and stenoporoid bryozoans (Leonardian to Guadalupian).

3. 23462-PC; same locality: Waagenoconcha sp., Rhynchopora sp., Cleiothyridina sp., and Tomiopsis(?) sp. (Leonardian to Guadalupian).

4. 23461-PC; same locality: Septospirifer $\mathrm{sp}$.

5. 23460-PC; same locality: Martinia sp.

23459-PC; Demarcation Point quadrangle; mountain northeast of Bathtub Ridge; lat $69^{\circ} 06^{\prime} 20^{\prime \prime} \mathrm{N}$, long $142^{\circ} 08^{\prime} \mathrm{W}$; $11.6 \mathrm{~km}$ (7.2 mi) N. $5^{\circ} \mathrm{E}$. of point where Kongakut River enters Table Mountain quadrangle; $100 \mathrm{~m}(350 \mathrm{ft})$ above base: Septospirifer(?) sp., and straparollid snails.

23458-PC; same locality; $80.7 \mathrm{~m}$ (265 ft) above base: Anidanthus(?) sp., Waagenoconcha sp., Spiriferella sp., and Septospirifer sp. (Leonardian to Guadalupian).

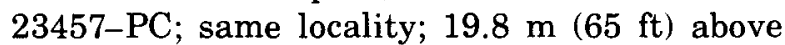
base: Chonetes sp. and Attenuatella sp. (Wolfcampian).

72ADt-388, unit 1; Sagavanirktok quadrangle; east bank of Flood Creek; lat $69^{\circ} 00^{\prime} \mathrm{N}$., long $147^{\circ} 55^{\prime} \mathrm{W}$.; $6.4 \mathrm{~km}$ (4 mi) south of junction with Ivishak River; $27.4 \mathrm{~m}$ (90 ft) above base: Anidanthus sp., Attenuatella sp., Martinia sp., Cancrinella(?) sp., Tomiopsis(?) sp., Straparollus sp., and horn corals (Wolfcampian).

72ADt-388, unit 2; same locality; 128 to $158.5 \mathrm{~m}$ (420 to $520 \mathrm{ft}$ ) above base: Martiniopsis sp., Cancrinella(?) sp., and Attenuatella sp., (Wolfcampian to Leonardian).

57 AMg3; north side of Joe Creek; $16.1 \mathrm{~km}$ (10 mi) west of Alaska-Canada boundary; lat $68^{\circ} 58^{\prime}$ N., long $141^{\circ} 24^{\prime} \mathrm{W}$; lower part below chert beds: Chonetinella sp., Martina(?) sp., Attenuatella sp., and Spiriferella sp., (Wolfcampian).

IKIAKPAURAK MEMBER (UPPER PERMIAN) 1. 24378-PC; Mt. Michelson quadrangle; type section, Ikiakpaurak Valley; lat $69^{\circ} 27^{\prime} 45^{\prime \prime} \mathrm{N}$., long $145^{\circ} 53^{\prime} 30^{\prime \prime} \mathrm{W}$.; $11.6 \mathrm{~km}(7.2 \mathrm{mi})$ N. $49^{\circ} \mathrm{E}$. of Shublik Island: Stenoscisma(?) sp.

2.24377-PC; same locality: Attenuatella sp., and Chonetes cf. C. superba (Gobbett) (Guadalupian).

3. 24376-PC; same locality: Arctitreta cf. $A$. kempei (Wiman), Megousia sp., Spiriferella keilhavii (Von Buch), Dielasma sp., Pterospirifer(?) alatus (Schlotheim), and Pseudogastrioceras(?) sp.

24381; Mt. Michelson quadrangle; ridge east of Pogopuk Creek; lat $69^{\circ} 18^{\prime} 30^{\prime \prime}$ N., long $146^{\circ} 34^{\prime} 30^{\prime \prime}$ W.; 9.1 to $10.7 \mathrm{~m}$ (30 to $35 \mathrm{ft}$ ) above base: Neophricodothyris asiatica (Chao), Stenoscisma(?) sp., Liosotella(?) pseudohorrida (Wiman), stenoporid and fenestrate bryozoans, and echinoderm debris (Guadalupian).

24382; same locality: 28.9 to $30.8 \mathrm{~m}$ (95 to $101 \mathrm{ft}$ ) above base: Chonetes cf. $C$. superba (Gobbett), Attenuatella sp., Spiriferella saranae (de Verneuil), R hynchopora sp., and pelecypod prisms.

24383; same locality; 41.5 to $45.4 \mathrm{~m}$ (136 to $149 \mathrm{ft}$ ) above base: Megousia sp., Stenoscisma cf. $S$. kochi (Dunbar), Pterospirifer alatus (Schlotheim), Rhynchopora sp., stenoporid bryozoans, and horn corals (Guadalupian).

24384; same locality; 51.2 to $54.3 \mathrm{~m} \mathrm{(168} \mathrm{to} 178 \mathrm{ft}$ ) above base: Neophricodothyris sp., Neospirifer sp., and gastropods (Guadalupian).

24396; Mt. Michelson quadrangle; north side of Kikiktat Mountain; lat $69^{\circ} 26^{\prime}$ N., long $144^{\circ} 36^{\prime}$ W.; 0 to $1.5 \mathrm{~m} \mathrm{(0} \mathrm{to} 5 \mathrm{ft}$ ) above base: Megousia weyprechti (Toula) and Spiriferella saranae (de Verneuil) (Guadalupian).

24397; same locality; 1.8 to $12.5 \mathrm{~m}$ (6 to $41 \mathrm{ft}$ ) above base: Derbyia(?) sp., Megousia sp., Stenoscisma sp., and Spiriferella sp. (Guadalupian).

24398; same locality; 18.6 to $24.7 \mathrm{~m}$ (61 to $81 \mathrm{ft}$ ) above base: Waagenoconcha irginae (Stuckenberg), Megousia(?) sp., Pterospirifer alatus (Schlotheim), Spiriferella sp., and gastropods (Guadalupian).

\section{IVISHAK FORMATION (LOWER TRIASSIC)}

\section{KAVIK MEMBER}

1. M6060 (U.S. Geological Survey Menlo Park Mesozoic locality); Mt. Michelson quadrangle; stream cut, right bank, Kavik River; lat $69^{\circ} 17^{\prime} 45^{\prime \prime}$ N., long $146^{\circ} 22^{\prime}$ W.: Ophiceras commune Spath (Griesbachian).

Collections from this locality made prior to 1969 
(Keller and others, 1961) contained Ophiceras commune Spath, Ophiceras cf. O. greenlandicum, Proptychites cf. $P$. rosenkrantzei, Claraia stachei Bittner, and Otoceras boreale Spath (Griesbachian).

\section{LEDGE SANDSTONE MEMBER}

70ADt-270, unit 9; Mt. Michelson quadrangle; north side of Kikiktat Mountain; lat $69^{\circ} 26^{\prime} 30^{\prime \prime}$ N., long $144^{\circ} 36^{\prime} 30^{\prime \prime} \mathrm{W}$.; $85.3 \mathrm{~m}(280 \mathrm{ft})$ above base of member: Euflemingites $\mathrm{cf}$ E. romunderi Tozer (Smithian).

\section{FIRE CREEK SILTSTONE MEMBER}

1. M6050; Mt. Michelson quadrangle; ridge west of Fire Creek; lat $69^{\circ} 31^{\prime} 30^{\prime \prime}$ N., long $145^{\circ} 17^{\prime} 30^{\prime \prime}$ W.: Euflemingites romunderi Tozer (Smithian).

M6061; Mt. Michelson quadrangle; mountain south of Wahoo Lake; lat $69^{\circ} 01^{\prime} 50^{\prime \prime} \mathrm{N}$.; long $146^{\circ} 54^{\prime} 50^{\prime \prime} \mathrm{W}$.; 70.1-76.2 m (230-250 ft) above base of member: Euflemingites cf. E. romunderi Tozer (Smithian).

\section{SHUBLIK FORMATION (UPPER TRIASSIC)}

1. M6067; Mt. Michelson quadrangle; Fire Creek; lat $69^{\circ} 31^{\prime} 45^{\prime \prime}$ N., long $145^{\circ} 12^{\prime} 20^{\prime \prime}$ W.: Monotis cf. $M$. obtusicostata Westermann, Halobia cf. $H$. fallax Mojsisovics, $H$. cf. $H$. lineata Mojsisovics, and Gryphaea sp. (Norian).

2. M6059; same locality: Monotis scutiformis pinensis Westermann, and Halobia of. H. fallax Mojsisovics (Norian).

3. M6058; same locality: Monotis cf. M. scutiformis Westermann, Halobia ef. H. fallax Mojsisovics, Gryphaea sp., and rhynchonellid brachiopods (Norian).

4. M6057; same locality: Halobia cf. H. zitteli Lindstrom, $H$. ornatissima, and Sirenites sp. (Karnian).

5. M6056; same locality: Halobia cf. H. zitteli Lindstrom, Leptochondria nationalis Smith, Gryphaea sp., Lima sp., arcestid ammonites, rhynchonellid brachiopods, and gastropods (Karnian).

6. M6055; same locality: unidentified pectenacids.

7. M6054; same locality: Daonella frami Kittl (Ladinian).

8. M6053; same locality: Daonella frami Kittl, Lima sp., Camptonectes sp., and spiriferid brachiopods (Ladinian).

9. M6052; same locality: Daonella frami Kittl, and Leiophyllites sp. (Anisian to Ladinian).

M6070; Mt. Michelson quadrangle; east bank, Echooka River; $3.2 \mathrm{~km}(2 \mathrm{mi}) \mathrm{N} .25^{\circ}$ E. of Wahoo Lake; lat $69^{\circ} 07^{\prime} 20^{\prime \prime} \mathrm{N}$., long $146^{\circ} 53^{\prime}$ W.; $28.3 \mathrm{~m}$
(93 ft) above base: Daonella frami Kittl (Ladinian).

M6071; same locality; $37.5 \mathrm{~m}$ (123 ft) above base: Halobia cf. H. ornatissima (Karnian).

M6072; same locality; 46.6 to $48.7 \mathrm{~m}$ (153 to $160 \mathrm{ft}$ ) above base: Arctosirenites cf. A. canadensis Tozer, Juvavites sp., Arcestes sp., and Halobia cf. $H$. ornatissima (Karnian).

M6073; same locality; 57.6 to $57.9 \mathrm{~m}$ (189 to $190 \mathrm{ft}$ ) above base: Halobia zitteli, $H$. ornatissima, and Psioidea sp. (Karnian).

M6074; same locality; 57.9 to $68.6 \mathrm{~m}$ (190 to $225 \mathrm{ft}$ ) above base: Halobia sp., Psioidea(?) sp., and ammonites.

M6075; same locality; $109.8 \mathrm{~m}$ (360 ft) above base: Monotis subcircularis and $M$. ochotica densistriata (Norian).

$72 \mathrm{ABe} 312 \mathrm{~B}$; Arctic quadrangle; near top of southwest side of Mount Annette; lat $68^{\circ} 45^{\prime}$ N., long $146^{\circ} 29^{\prime}$ W.; in chert and shale unit: Monotis sp. indet. (middle or upper Norian).

$72 \mathrm{ABe} 284 \mathrm{C}$; Arctic quadrangle; hill about $14.5 \mathrm{~km}$ (9 mi) east of Mount Annette; lat $68^{\circ} 47^{\prime}$ N., long $146^{\circ} 12^{\prime} \mathrm{W}$; in chert and shale unit: Monotis sp. indet. but similar to $M$. subcircularis or $M$. ochotica of late Norian age.

72ABe314; Arctic quadrangle; hill $1.6 \mathrm{~km}$ (1 mi) south-southwest of Mount Annette; lat $68^{\circ} 44^{\prime} 30^{\prime \prime}$ $\mathrm{N}$., long $146^{\circ} 29^{\prime} \mathrm{W}$; in unit of shale, chert, and limestone: Monotis sp. indet., and Halobia sp. indet. but probably of Norian type (probably middle Norian).

72ABe316A; Arctic quadrangle; hill $4.8 \mathrm{~km}$ (3 mi) northeast of Mount Annette; lat $68^{\circ} 46^{\prime} 30^{\prime \prime}$ N., long $146^{\circ} 23^{\prime} \mathrm{W}$.; in (lower? part of shale and limestone member: Halobia cf. $H$. zitteli group (Karnian or lower Norian).

68ATo12 (M6065); Arctic quadrangle; south bank of Porcupine Lake; lat $68^{\circ} 47^{\prime} 5^{\prime \prime} \mathrm{N}$., long $146^{\circ} 28^{\prime}$ W.; in shale and limestone member: Halobia cf. H. zitteli-ornatissima group, and tropitid ammonites (upper Karnian).

68ATo11; Arctic quadrangle; creek about $2.4 \mathrm{~km}$ (1 $\left.1 \frac{1}{2} \mathrm{mi}\right)$ northwest of Porcupine Lake; lat $68^{\circ} 48^{\prime}$ $\mathrm{N}$., long $146^{\circ} 31^{\prime} \mathrm{W}$; in shale and limestone member: Halobia cf. H. zitteli-ornatissima group (Karnian).

\section{KAREN CREEK SANDSTONE (UPPER TRIASSIC)}

69ADt-106; Mt. Michelson quadrangle; Fire Creek; lat $69^{\circ} 32^{\prime} 10^{\prime \prime} \mathrm{N}$., long $145^{\circ} 11^{\prime} 25^{\prime \prime} \mathrm{W}$.; base of formation: Monotis ochotica ochotica (Keyserling), and Gryphaea keilhaui Boehm (late Norian). 
KINGAK SHALE (JURASSIC)

1. 29856 mes. loc. (U.S. Geological Survey Mesozoic locality); Mt. Michelson quadrangle; east end of Ignek Valley; $10.9 \mathrm{~km}(6.8 \mathrm{mi}) \mathrm{S}$. $75^{\circ}$ E. of Katakturuk Canyon; lat $69^{\circ} 33^{\prime} 30^{\prime \prime}$ N., long $145^{\circ} 20^{\prime}$ W.: Cardioceras (Scarburgiceras) sp. and Inoceramus sp. (Oxfordian).

2. 29877 mes. loc.; same locality: Arcticoceras cf. A. kochi Spath (Bathonian).

3. 29855 mes. loc.; same locality: Cranocephalites ignekensis Imlay (Bathonian).

4. 29875 mes. loc.; same locality: Cranocephalites sp. Inoceramus sp., and Grammatodon(?) sp. (Bathonian).

5. 70ADt-215, unit 51 ; same locality: Inoceramus sp.

6. 29854 mes. loc.; same locality: Inoceramus cf. I. ambiguus and belemnites (Bajocian).

7. 29876 mes. loc.; same locality: Inoceramus. lucifer Eichwald, Oxytoma sp., Meleagrinella sp., and ammonite fragments (Bajocian).

8. 30075 mes. loc.; Demarcation Point quadrangle; west bank Aichilik River; $4 \mathrm{~km}$ (2.5 mi) N. $30^{\circ}$ E. of VABM Atte; lat $69^{\circ} 33^{\prime}$ N., long $143^{\circ} 05^{\prime}$ W.: Arctioceras kochi Spath, A. kochi var. pseudolamberti Spath, and Choffatia cf. $C$. subbakeriae (d'Orbigny) (Bathonian).

9. 30074 mes. loc.; same locality: Amaltheus cf. A. stokesi (Sowerby) and Ostrea sp. (Pliensbachian).

10. 30073 mes. loc.; same locality: Pentacrinus sp. and pelecypod fragments (Early Jurassic).

29883 mes. loc.; Mt. Michelson quadrangle; west bank, Kavik River; lat $69^{\circ} 16^{\prime} 20^{\prime \prime}$ N., long $146^{\circ} 22^{\prime} \mathrm{W}$.; lower $45.7 \mathrm{~m}$ (150 ft): Otapiria tailleuri Imlay (Sinemurian to early Bajocian).

30135 mes. loc.; Demarcation Point quadrangle; ridge west of Okerokovik River; $12.2 \mathrm{~km}(7.6$ $\mathrm{mi}) \mathrm{S} .80^{\circ} \mathrm{W}$. of VABM Matte; lat $69^{\circ} 28^{\prime} 45^{\prime \prime} \mathrm{N}$., long $143^{\circ} 25^{\prime} 50^{\prime \prime} \mathrm{W}$; position unknown: Pseudolioceras maclintocki (Haughton) (basal Bajocian).

29885 mes. loc.; Mt. Michelson quadrangle; ridge west of Kaviak Creek; lat $69^{\circ} 27^{\prime} 30^{\prime \prime}$ N., long $145^{\circ} 04^{\prime} 30^{\prime \prime}$ W.; position unknown: Pentacrinus subangularis var. alaska Springer and Inoceramus cf. I. lucifer Eichwald (Bajocian).

29884 mes. loc.; same locality; about $15.2 \mathrm{~m} \mathrm{(50}$ ft) lower than 29885: Canavarella cf. $C$. belophora Buckman, Pseudolioceras cf. $P$. maclintocki (Haughton), and Inoceramus cf. $I$. lucifer Eichwald (basal Bajocian).

30267, 30268, 30269, 30270 mes. loc.; Mt. Michelson quadrangle; Ignek Valley; $0.8 \mathrm{~km}$
(0.5 mi) south of entrance to Katakturuk Canyon; lat $69^{\circ} 35^{\prime} \mathrm{N}$, long $145^{\circ} 36^{\prime} 30^{\prime \prime} \mathrm{W}$.; 33.5 to $97.5 \mathrm{~m} \mathrm{(110} \mathrm{to} 320 \mathrm{ft}$ ) above base: Canavarella sp., Pseudolioceras maclintocki (Haughton), and Erycitoides sp. (basal Bajocian).

30266 mes. loc.; Mt. Michelson quadrangle, west bank of Canning River opposite Shublik Island; lat $69^{\circ} 24^{\prime} \mathrm{N}$., long $146^{\circ} 10^{\prime} \mathrm{W}$.; upper part of section, exact position unknown: Arkelloceras cf. A. mclearni Frebold sp. and Inoceramus sp. (early middle Bajocian).

30136 mes. loc.; Demarcation Point quadrangle; west bank of Aichilik River; lat $69^{\circ} 33^{\prime} \mathrm{N}$., long $143^{\circ} 05^{\prime} \mathrm{W}$; ; about $426 \mathrm{~m}$ (1.400 ft) above base of Kingak Shale: Cadoceras sp. (Callovian).

30076 mes. loc.; Table Mountain quadrangle; south bank of Joe Creek; lat $68^{\circ} 57^{\prime} 20^{\prime \prime}$ N., long $141^{\circ} 23^{\prime} 30^{\prime \prime} \mathrm{W}$; $18.5 \mathrm{~km}(11.5 \mathrm{mi})$ west of Alaska-Canada boundary: Buchia rugosa (Fischer) (Kimmeridgian to Tithonian).

Black Island in the Canning River has been known for many years as a locality for well-preserved Pentacrinus subangularis var. alaska Springer. Many specimens of this fossil have been collected for museums. During the present investigation a number of new localities were found that contain equally well preserved material. Localities in the Mt. Michelson quadrangle, in addition to Black Island, include Fire Creek, lat $69^{\circ} 32^{\prime} 10^{\prime \prime} \mathrm{N}$, long $145^{\circ} 11^{\prime} 25^{\prime \prime} \mathrm{W}$; at the junction of Gravel Creek with the Sadlerochit River, lat $69^{\circ} 29^{\prime} 30^{\prime \prime} \mathrm{N}$., long $145^{\circ} 05^{\prime} 30^{\prime \prime}$ $\mathrm{W}$; on the ridge west of Kaviak Creek, lat $69^{\circ} 27^{\prime} 30^{\prime \prime} \mathrm{N}$., long $145^{\circ} 04^{\prime} 30^{\prime \prime} \mathrm{W}$; and on the mountain $1.6 \mathrm{~km}$ (1 mi) west of the upper Sadlerochit River, lat $69^{\circ} 19^{\prime} 40^{\prime \prime} \mathrm{N}$., long $145^{\circ} 23^{\prime} \mathrm{W}$. Localities in the Demarcation Point quadrangle include the west bank of the Aichilik River, lat $69^{\circ} 33^{\prime} \mathrm{N}$., long $143^{\circ} 05^{\prime} \mathrm{W}$.; and on a ridge west of the Okerokovik River, lat $69^{\circ} 28^{\prime} 45^{\prime \prime} \mathrm{N}$., long $143^{\circ} 25^{\prime} 50^{\prime \prime} \mathrm{W}$.

\section{KONGAKUT FORMATION (LOWER CRETACEOUS)}

1. M5815 (U.S. Geological Survey, Menlo Park, Mesozoic locality number); Demarcation Point quadrangle; north flank of Bathtub Ridge; lat $69^{\circ} 06^{\prime} 10^{\prime \prime}$ N., long $142^{\circ} 17^{\prime}$ W.: Aucellina(?) sp. (Aptian?).

2. M5817; same locality: Simbirskites sp., Lytoceras sp., belemnites, and brachiopods (Hauterivian).

3. M5818; same locality: Buchia sublaevis (Imlay) (Valanginian).

70ADt-214; Demarcation Point quadrangle; north side of Bathtub Ridge; lat $69^{\circ} 07^{\prime} 45^{\prime \prime} \mathrm{N}$., long $142^{\circ} 37^{\prime}$ W.; $30.5 \mathrm{~m}$ (100 ft) above base: Buchia sublaevis (Imlay) (Valanginian). 
M5581; Sagavanirktok quadrangle; east side of Kemik Creek; lat $69^{\circ} 21^{\prime} 41^{\prime \prime}$ N., long $147^{\circ} 21^{\prime} 43^{\prime \prime}$ W.; position unknown: Buchia keyserlingi(?) (Berriasian).

M5584; Mt. Michelson quadrangle; divide between Kavik River and Juniper Creek; lat $69^{\circ} 28^{\prime} 30^{\prime \prime} \mathrm{N}$., long $146^{\circ} 38^{\prime} 20^{\prime \prime}$ W.; Buchia keyserlingi(?) (Berriasian).

\section{KEMIK SANDSTONE MEMBER (LOWER CRETACEOUS)}

1. 69ADt-29; Mt. Michelson quadrangle; Ignek Valley; lat $69^{\circ} 34^{\prime} 58^{\prime \prime} \mathrm{N}$., long $145^{\circ} 42^{\prime} 50^{\prime \prime} \mathrm{W}$.: Astarte ignekensis Imlay, Ditrupa cornu Imlay, Panope sp., and Pleuromya sp. (Valanginian to Albian).

70ABe-262; Mt. Michelson quadrangle; north side of Sadlerochit Mountains; lat $69^{\circ} 38^{\prime} \mathrm{N}$., long $145^{\circ} 25^{\prime} \mathrm{W}$.; position unknown: Astarte ignekensis Imlay and Ditrupa sp. (Valanginian to Albian).

69ADt-51; Mt. Michelson quadrangle; Ignek Valley; lat $69^{\circ} 33^{\prime} 20^{\prime \prime} \mathrm{N}$., long $145^{\circ} 27^{\prime} 45^{\prime \prime} \mathrm{W}$; upper part of sandstone: Astarte ignekensis Imlay and Pleuromya sp. (Valanginian to Albian).

\section{NANUSHUK GROUP}

\section{TUKTU FORMATION (LOWER CRETACEOUS)}

1. $70 \mathrm{ABe}-134 \mathrm{~A} ; \mathrm{Mt}$. Michelson quadrangle; ridge east of Arctic Creek; lat $69^{\circ} 29^{\prime} 30^{\prime \prime}$ N., long 144'32'30" W.: Paragastroplites spiekeri (McLearn) (Albian).

2. 70ABe-135; same locality: Inoceramus sp. prisms.

3. $70 \mathrm{ABe}-135 \mathrm{~B}$; same locality; lat $69^{\circ} 30^{\prime} \mathrm{N}$., long 144 $31^{\circ}$ ' W.: Paragastroplites spiekeri (McLearn) (Albian).

\section{SEABEE FORMATION (UPPER CRETACEOUS)}

SHALE WALL MEMBER

71ADt-353; Demarcation Point quadrangle; west bank of Jago River; lat $69^{\circ} 54^{\prime} 30^{\prime \prime} \mathrm{N}$., long $143^{\circ} 24^{\prime} 30^{\prime \prime}$ W.: abundant fossil fish, not identified.

\section{SAGAVANIRKTOK FORMATION (TERTIARY)}

NUWOK MEMBER (LATE MIOCENE? AND PLIOCENE)

1. M4148, 4427 (U.S. Geological Survey, Menlo Park, Cenozoic locality); Mt. Michelson quadrangle; bluff on east side of Carter Creek; 3.2 $\mathrm{km}(2 \mathrm{mi})$ south of Arctic Ocean; lat $69^{\circ} 56^{\prime} 45^{\prime \prime}$ N., long $144^{\circ} 39^{\prime} 50^{\prime \prime}$ W.: Chlamys cf. $C$. nuwokensis MacNeil, Thyasira alaskana Kauffman, Astarte sp., Terebratula aff. $T$. grandis Davidson, Buccinum sp., and Polinices(?) sp. (late Miocene or Pliocene).

2. M4147; same locality: Cyclocardia cf. $C$. nuwokensis (Dall), Cyrtodaria sp., Astarte sp., and Terebratula sp. (late Miocene or Pliocene).

\section{GUBIK FORMATION (PLEISTOCENE)}

1. 70ADt-275; Demarcation Point quadrangle; tributary of Niguanak River; lat $69^{\circ} 49^{\prime} 30^{\prime \prime} \mathrm{N}$., long $143^{\circ} 05^{\prime} 10^{\prime \prime} \mathrm{W} .:$ Populus (Salicaceae) sp.; this wood dated by C-14 method at $>34,000$ years b.p.

\section{REFERENCES CITED}

Bamber, E. W., and Waterhouse, J. B., 1971, Carboniferous and Permian stratigraphy and paleontology, northern Yukon Territory, Canada: Alberta Soc. Petroleum Geologists Bull., v. 19, no. 1, p. 29-250.

Basye, Dale, 1969, Secrecy shroud lifts on giant Prudhoe Bay Field: Oil and Gas Jour., v. 67, no. 47, p. 49-54.

Bergquist, H. R., 1966, Micropaleontology of the Mesozoic rocks of northern Alaska: U.S. Geol. Survey Prof. Paper 302-D, p. 93-227.

Black, R. F., 1964, Gubik Formation of Quaternary age in northern Alaska: U.S. Geol. Survey Prof. Paper 302-C, p. 59-91.

Boneham, R. F., and Tailleur, I. L., 1972, Leiospheridia (Acritarcha) in the Mesozoic oil shales of northern Alaska, in Geological Survey research 1972: U.S. Geol. Survey Prof. Paper 800-B, p. B17-B19.

Brosgé, W. P., Dutro, J. T., Jr., Mangus, M. D., and Reiser, H. N., 1962 Paleozoic sequence in eastern Brooks Range, Alaska: Am. Assoc. Petroleum Geologists Bull., v. 46, p. 2174-2198.

Brosgé, W. P., and Tailleur, I. L., 1969, Isopach maps of upper Paleozoic and Mesozoic rocks, northern Alaska: U.S. Geol. Survey open-file report, $10 \mathrm{p}$.

- 1970, Depositional history of northern Alaska, in Adkison, W. L., and Brosgé, M. M., eds., Proceedings of the geologic seminar on the North Slope of Alaska: Los Angeles, Pacific Sec. Am. Assoc. Petroleum Geologists, p. D1-D18.

Brosgé, W. P., and Whittington, C. L., 1966, Geology of the Umiat-Maybe Creek region, Alaska: U.S. Geol. Survey Prof. Paper 303-H, p. 501-638.

Chapman, R. M., Detterman, R. L., Mangus, M. D., 1964, Geology of the Killik-Etiuluk Rivers region, Alaska: U.S. Geol. Survey Prof. Paper 303-F, p. 325-407.

Dall, W. H., 1919, Mollusks, Recent and Pleistocene: Report of the Canadian Arctic Expedition 1913-18, v. 8, pt. A. Ottawa. 1920, Pliocene and Pleistocene fossils from the Arctic coast of Alaska and the auriferous beaches of Nome, Norton Sound, Alaska: U.S. Geol. Survey Prof. Paper 125-C, p. 23-37.

Detterman, R. L., 1956a, New and redefined nomenclature of the Nanushuk Group, in Gryc, George, and others, Mesozoic sequence in Colville River region, northern Alaska: Am. Assoc. Petroleum Geologists Bull., v. 40, no. 2, p. 233-244.

1956b, A new member of the Seabee Formation, Colville Group, in Gryc, George, and others, The Mesozoic sequence in Colville River region, northern Alaska: Am. Assoc. Petroleum Geologists Bull., v. 40, p. 253-254.

1970a, Sedimentary history of Sadlerochit and Shublik Formations in northeastern Alaska, in Adkison, W. L., and Brosgé, M. M., eds., Proceedings of the geologic seminar on the 
North Slope of Alaska: Los Angeles, Pacific Sec. Am. Assoc. Petroleum Geologists, p. 1-13.

1970b, Analysis of Shublik Formation rocks from Mt. Michelson quadrangle, Alaska: U.S. Geol. Survey open-file report, 1 p., 3 charts.

1971, Arctic Mesozoic correlation chart: U.S. Geol. Survey open-file report, 1 sheet.

1973, Mesozoic sequence in Arctic Alaska, in Proceedings of 2d International Arctic Symposium: Am. Assoc. Petroleum Geologists Mem., p. 376-387.

Detterman, R. L., Bickel, R. S., and Gryc, George, 1963, Geology of the Chandler River region, Alaska: U.S. Geol. Survey Prof. Paper 303-E, p. 223-324.

Fackler, W. C. (chm., North Slope Stratigraphic Committee), 1971, West to east stratigraphic correlation section Pt. Barrow to Ignek Valley, Arctic North Slope, Alaska: Alaska Geol. Soc., Anchorage, Alaska.

Gryc, George, and Mangus, M. D., 1947, Preliminary report on the stratigraphy and structure of the area of the Shaviovik and Canning Rivers, Alaska: U.S. Geol. Survey open-file report, 7 p.

Gryc, George, Patton, W. W., Jr., and Payne, T. G., 1951, Present Cretaceous stratigraphic nomenclature of, northern Alaska: Washington Acad. Sci. Jour., v. 41, no. 5, p. 159-167.

Gryc, George, and others, 1956, Mesozoic sequence in Colville River region, northern Alaska: Am. Assoc. Petroleum Geologists Bull., v. 40 , no. 2 , p. $209-254$.

Imlay, R. W., 1959, Succession and speciation of the pelecypod Aucella: U.S. Geol. Survey Prof. Paper 314-G, p. 155-169.

1961, Characteristic lower Cretaceous megafossils from northern Alaska: U.S. Geol. Survey Prof. Paper 335, p. 74

Imlay, R. W., and Detterman, R. L., 1973, Jurassic paleobiogeography of Alaska: U.S. Geol. Survey Prof. Paper 801, 34 p.

Jones, D. L., and Gryc, George, 1960, Upper Cretaceous pelecypods of the Genus Inoceramus from northern Alaska: U.S. Geol. Survey Prof. Paper 334-E, p. 149-165.

Keller, A. S., Morris, R. H., and Detterman, R. L., 1961, Geology of the Shaviovik and Sagavanirktok Rivers region, Alaska: U.S. Geol. Survey Prof. Paper 303-D, p. 169-222.

Leffingwell, E. de K., 1919, The Canning River region, northern Alaska: U.S. Geol. Survey Prof. Paper 109, 251 p.

MacNeil, F. S., 1957, Cenozoic megafossils of northern Alaska: U.S. Geol. Survey Prof. Paper 294-C, p. 99-126.

MacNeil, F. S., Wolfe, J. A., Miller, D. J., and Hopkins, D. M., 1961, Correlation of Tertiary formations of Alaska: Am. Assoc. Petroleum Geologists Bull., v. 45, no. 11, p. 1801-1809.

Maddren, A. G., 1912, Geologic investigations along the CanadaAlaska boundary: U.S. Geol. Survey Bull. 520, p. 297-314.

Mangus, M. D., and Pessel, G. H. (chm., North Slope Stratigraphic Committee), 1972, Northwest to southeast stratigraphic correlation section Prudhoe Bay to Ignek Valley, Arctic North Slope, Alaska: Alaska Geol. Soc., Anchorage, Alaska, 1 sheet.

Morris, R. H., 1953, Reconnaissance study of the Marsh anticline, northern Alaska: U.S. Geol. Survey open-file report, $6 \mathrm{p}$.

Mountjoy, E. W., 1967, Triassic stratigraphy of northern Yukon Territory: Geol. Survey Canada Paper 66-19, p. 28-31.

Norris, D. K., 1972, Structural and stratigraphic studies in the tectonic complex area of northern Yukon Territory, north of Porcupine River: Canada Geol. Survey, Report of activities, Paper 72-1, Part B, p. 91-99.

Patton, W. W., Jr., and Tailleur, I. L., 1964, Geology of the
Killik-Itkillik region, Alaska: U.S. Geol. Survey Prof. Paper 303-G, p. 409-500.

Porter, S. C., 1966, Pleistocene geology of Anaktuvuk Pass, central Brooks Range, Alaska: Arctic Inst. North America, Tech. Paper $18,100 \mathrm{p}$.

Potter, P. E., and Pettijohn, F. J., 1963, Paleocurrents and basin analysis: Berlin, Springer-Verlag, $291 \mathrm{p}$.

Reed, B. L., 1968, Geology of the Lake Peters area, northeastern Brooks Range: U.S. Geol. Survey Bull. 1236, 132 p.

Reiser, H. N., 1970, Northeastern Brooks Range-a surface expression of the Prudhoe Bay section, in Adkison, W. L., and Brosgé, M. M., eds., Proceedings of the geological seminar on the North Slope of Alaska: Los Angeles, Pacific Sec. Am. Assoc. Petroleum Geologists, p. K1-K13.

Reiser, H. N., Brosgé, W. P., Dutro, J. T., Jr., and Detterman, R. L., 1971, Preliminary geologic map, Mt. Michelson quadrangle, Alaska: U.S. Geol. Survey open-file report, 2 sheets.

1974, Preliminary geologic map of the Demarcation Point quadrangle, Alaska: U.S. Geological Survey open-file map, 1 sheet.

Reiser, H. N., Dutro, J. T., Jr., Brosgé, W. P., Armstrong, A. K., and Detterman, R. L., 1970, Progress map, geology of the Sadlerochit and Shublik Mountains, Mt. Michelson $\mathrm{C}-1, \mathrm{C}-2, \mathrm{C}-3$, and $\mathrm{C}-4$ quadrangles, Alaska: U.S. Geol. Survey open-file report, 4 sheets.

Reiser, H. N., and Tailleur, I. L., 1969, Preliminary geologic map of Mt. Michelson quadrangle, Alaska: U.S. Geol. Survey open-file report, 1 sheet.

Rickwood, F. K., 1970, The Prudhoe Bay field, in Adkison, W. L., and Brosgé, M. M., eds., Proceedings of the geological seminar on the North Slope of Alaska: Los Angeles, Pacific Sec. Am. Assoc. Petroleum Geologists, p. L1-L11.

Rucklin, H., 1938, Strömungsmarken im unteren Muschelkalk des Saarlandes: Senckenbergiana 20, p. 94-114.

Sable, E. G., 1965, Geology of the Romanzof Mountains, Brooks Range, northeastern Alaska: U.S. Geol. Survey open-file report, $218 \mathrm{p}$.

Schrader, F. C., 1902, Geological section of the Rocky Mountains in northern Alaska: Geol. Soc. America Bull. 13, p. 233-252.

1904, A reconnaissance in northern Alaska: U.S. Geol. Survey Prof. Paper 20, 139 p.

Silberling, N. J., and Patton, W. W. Jr., 1964, Triassic rocks of Brooks Range, in Geological Survey research 1964: U.S. Geol. Survey Prof. Paper 501-A, p. A116.

Smith, P. S., 1939, Areal geology of Alaska: U.S. Geol. Survey Prof. Paper 192, $100 \mathrm{p}$

Todd, Ruth, 1957, Foraminifera from Carter Creek, northeastern Alaska: U.S. Geol. Survey Prof. Paper 294-F, p. 223-235.

Tourtelot, H. A., and Tailleur, I. L., 1971, The Shublik Formation and adjacent strata in northeastern Alaska: U.S. Geol. Survey open-file report, $62 \mathrm{p}$.

Whittington, C. L., 1956, Revised stratigraphic nomenclature of Colville Group, in Gryc, George, and others, Mesozoic sequence in Colville River region, northern Alaska: Am. Assoc. Petroleum Geologists Bull., v. 40, p. 244-253.

Whittington, C. L., and Sable, E. G., 1948, Preliminary geologic report of the Sadlerochit River area: U.S. Geol. Survey open-file report, $18 \mathrm{p}$.

Williams, Howel, Turner, F. J., and Gilbert, C. M., 1958 , Petrography - an introduction to the study of rocks in thin sections: San Francisco, W. H. Freeman Co., 406 p. 

. 